\author{
UNIVERSIDADE DE SÃO PAULO \\ Faculdade de Filosofia, Letras e Ciências Humanas \\ Departamento de Geografia \\ Programa de Pós Graduação em Geografia Humana
}

RENATO SUANO PACHECO DE ARAUJO

\title{
A VIABILIZAÇÃO DE PARQUES COM APOIO DO TURISMO O caso do Parque Estadual de Campos do Jordão
}


RENATO SUANO PACHECO DE ARAUJO

\section{A VIABILIZAÇÃO DE PARQUES COM APOIO DO TURISMO $O$ caso do Parque Estadual de Campos do Jordão}

Dissertação apresentada ao Departamento de Geografia da Faculdade de Filosofia Letras e Ciências Humanas da Universidade de São Paulo como requisito parcial para a obtenção do título de Mestre em Geografia

Área de Concentração: Geografia Humana Orientador: Prof. Dr. Eduardo Abdo Yázigi

São Paulo

2008 
AUTORIZO A REPRODUÇÃo E DIVULGAÇÃO TOTAL OU PARCIAL DESTE TRABALHO, POR QUAALUER MEIO CONVENCIONAL OU ELETRÔNICO, PARA FINS DE ESTUDO E PESQUISA, DESDE QUE CITADA A FONTE. 


\section{FOLHA DE APROVAÇÃO}

Renato Suano Pacheco de Araujo

A Viabilização de Parques com o Apoio do Turismo - O Caso do Parque Estadual de Campos do Jordão.

Dissertação apresentada ao Departamento de Geografia da Faculdade de Filosofia Letras e Ciências Humanas da Universidade de São Paulo como requisito parcial para a obtenção do título de Mestre em Geografia

Área de Concentração: Geografia Humana

Aprovado em:

Banca Examinadora

Prof. Dr. (a)

Instituição: Assinatura:

Prof. Dr. (a)

Instituição: Assinatura:

Prof. Dr. (a)

Instituição: Assinatura: 
Para meu irmão Frederico; 


\section{Agradecimentos}

Agradeço a todas as pessoas que, de alguma forma, ajudaram no processo desta pesquisa.

Ao Prof. Dr. Eduardo Yázigi, que orientou o trabalho de maneira firme e cuidadosa, devo total gratidão a sua generosa contribuição;

Ao amigo Oreste Bortolli Júnior, grande amigo que espero continue sempre presente na minha vida;

Aos meus pais, Luiz Felipe e Marilene, que nunca faltaram com o apoio emocional e material em todos os momentos da minha vida;

Aos professores Yuri Tavares Rocha e Luiz Antonio Bittar Venturi pelas preciosas contribuições na qualificação;

Ao amigo Joaquim dos Santos Filho, que sempre cuidou para que 'as noites' de mestrado fossem as melhores;

Ao pessoal do 'grupo do Yuri': Adenilson, Luciana, Luzia, Andrea, Joselani e José Hamilton pelos encontros inesquecíveis;

Para as amigas Glaucia Hokama, Mariana Leme e Bruna Charifker pela companhia mais que agradável;

Para Telma Helena que 'ensaiou' o lugar onde estou;

Para Patricia Ottoni, que agüentou muito durante boa parte do mestrado;

A Joaquim Gama e Paula Sorelli, por todas as manhãs de sábado na Uniban;

Para Francisco Cerialle, grande amigo que sempre me aconselhou pelos melhores caminhos e;

Para José Arapoty, pela ajuda na impressão do trabalho. 


\section{SUMÁRIO}

$\begin{array}{ll}\text { RESUMO } & 12\end{array}$

$\begin{array}{ll}\text { ABSTRACT } & 13\end{array}$

1. INTRODUÇÃO

$\begin{array}{ll}1.1 \text { Objetivo geral } & 17\end{array}$

$\begin{array}{ll}1.2 \text { Objetivos específicos } & 18\end{array}$

2. MÉTODO E PROCEDIMENTOS TÉCNICO-OPERACIONAIS 20

3. ÁREAS PROTEGIDAS - USOS E CARACTERÍSTICAS 22

$\begin{array}{lr}3.1 \text { Áreas protegidas no mundo } & 22\end{array}$

$\begin{array}{ll}\text { 3.2 Áreas protegidas no Brasil - as unidades de conservação } & 26\end{array}$

3.2.1 Parques Estaduais do Estado de São Paulo 32

$\begin{array}{ll}\text { 3.2.1.1 O Instituto Florestal } & 36\end{array}$

$\begin{array}{ll}\text { 3.3 Ecoturismo ou Turismo de Natureza } & 38\end{array}$

4. A PROTEÇÃO DOS PARQUES $\quad 50$

$\begin{array}{ll}\text { 4.1 Os residentes humanos nos parques } & 51\end{array}$

5. A QUESTÃO ECONÔMICA

$\begin{array}{ll}5.1 \text { Quanto custa um parque? } & 56\end{array}$

6. O PLANEJAMENTO PARA O TURISMO EM PARQUES 63

$\begin{array}{lr}6.10 \text { plano de manejo } & 68\end{array}$

$\begin{array}{lr}6.2 \text { Serviços de turismo e infra-estrutura em parques } & 69\end{array}$

$\begin{array}{ll}6.3 \text { Impactos do turismo em parques e seu entorno } & 71\end{array}$

7. ALGUMAS EXPERIÊNCIAS DE TURISMO EM PARQUES

8. CASO ESTUDADO

$\begin{array}{ll}\text { 8.1 } 0 \text { turismo em Campos do Jordão } & 75\end{array}$ 
9. CONSIDERAÇÕES FINAIS

10. BIBLIOGRAFIA

ANEXOS

125 


\section{ÍNDICE DE FIGURAS}

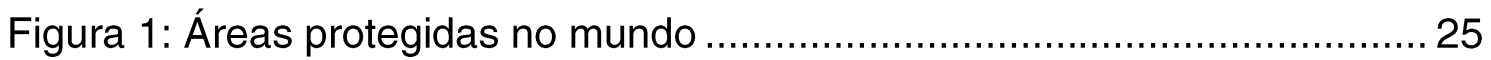

Figura 2: Parques Nacionais no Brasil .................................................... 31

Figura 3: Unidades de Conservação Gerenciadas pelo Instituto Florestal....... 35

Figura 4: Entrada principal do município de Campos do Jordão, onde se localiza a Secretaria de Turismo. Estaríamos entrando na Suíça? ................... 76 Figura 5: Identificação da Obra "Recuperação do Acesso ao Parque Estadual". A placa ao lado indica o valor da obra $(R \$ 1.199 .605,50)$ e a data de término



Figura 6: Alguns dos muitos buracos encontrados na "Estrada do Horto"....... 78 Figura 7: Primeira residência construída em 1855 no local denominado



Figura 8: Portal de entrada do Parque ..................................................... 80

Figura 9: Exemplo de sinalização do Parque, de difícil leitura, sem

padronização de letras ou símbolos........................................................... 80

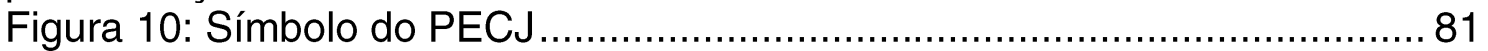

Figura 11: Galpão de artesanato - nota-se a desorganização.......................... 82

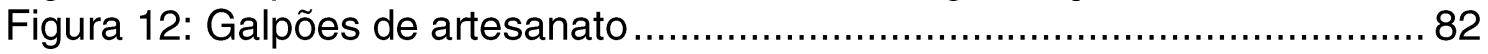

Figura 13: Artesanato local, executados com pequenas toras de araucária .... 83

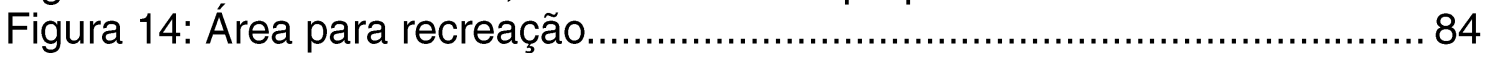

Figura 15: Viveiro de mudas, desorganizado e sem entrada apropriada ......... 85

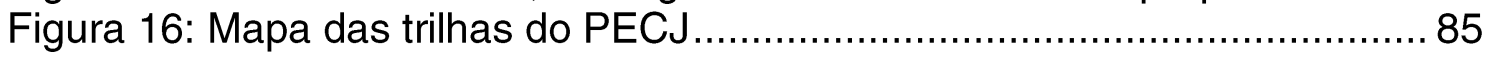

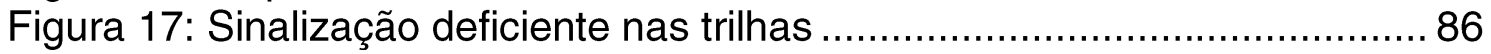

Figura 18: Foto tirada em março de 2007, como conseqüência das fortes

chuvas, a trilha da Celestina foi fechada. Apenas uma pequena fita indicava seu fechamento.

Figura 19: A presença de carro na trilha da Cachoeira. Faltam informações sobre a presença de automóveis na trilha.

Figura 20: Lanchonete do PECJ, com raras exceções as coberturas dos equipamentos são inadequadamente cobertas com fibro cimento.................... 88

Figura 21: Falta de telhas na sala de espera do posto de saúde ...................... 89

Figura 22: Instalações elétricas precárias no posto de saúde........................... 89

Figura 23: Sanitário externo, sem acessibilidade .......................................... 90

Figura 24: Fiação aparente no sanitário externo ........................................... 90

Figura 25: Posto telefônico.................................................................... 91

Figura 26: Mapa pálido e precário da malha urbana e dos pontos de interesse



Figura 27: Estacionamento do PECJ, desorganizado e sem sinalização.......... 92

Figura 28: Telhas metálicas corroídas na serraria .......................................... 93

Figura 29: Fiação elétrica exposta e desprotegida na serraria......................... 94

Figura 30: O prédio do centro de visitantes, onde se encontra o auditório, a biblioteca e a brinquedoteca................................................................... 95

Figura 31: Assentos não são adequados em altura e largura e não há tratamento acústico no auditório ................................................................... 96

Figura 32: Os poucos equipamentos audiovisuais do auditório ....................... 96

Figura 33: Biblioteca com poucas mesas e falta de espaço para pesquisas. .. 97

Figura 34: Brinquedoteca contígua a biblioteca ............................................... 98 
Figura 35: Buracos no chão da brinquedoteca e a presença de carpete

Figura 36: Brinquedo em péssimo estado de conservação

Figura 37: Presença de degraus na brinquedoteca..................................... 100

Figura 38: Trenzinho da floresta............................................................. 101

Figura 39: Hospedaria e restaurante do PECJ.......................................... 102

Figura 40: Instalações elétricas precárias na hospedaria ........................... 103

Figura 41: Instalações elétricas precárias na hospedaria ........................... 103

Figura 42: Falta de conduites para a fiação dos interruptores e luminárias ... 104

Figura 43: Cartão da hospedaria: a pobreza no desenho do cartão antecipa a precariedade das instalações.................................................................. 105

Figura 44: Sala de exposições e 'museu'................................................... 106

Figura 45: Peça no centro de exposições: mal identificada; ao fundo, as paredes que escondem a paisagem ...................................................... 107

Figura 46: Passeios e calçadas do PECJ não contemplam a paisagem........ 108

Figura 47: A fiação aérea e a iluminação fora da escala do pedestre............ 109

Figura 48: Os guarda-corpos, com peças em madeiramento cruzadas,

formando um ' $X$ ' ................................................................................. 110

Figura 49: Lixos mal conservados e sem coleta seletiva ............................ 110

Figura 50: A grafia correta seria Cunninghamia lanceolata. Todas as placas observadas apresentam o mesmo tipo de erro, com todas as letras em maiúscula.

Figura 51: Placa informativa no PECJ. Péssimo estado de conservação na maioria das placas deste tipo.

Figura 52: Mapa das Regiões Administrativas e Metropolitanas do Estado de São Paulo. 


\section{INDICE DE TABELAS}

Tabela 1: Índice de visitação em parques ................................................... 48

Tabela 2: Divisão dos fundos requeridos para o Yellowstone National Park ... 59

Tabela 3: Custo Anual do Parque Estadual da Serra do Mar........................... 60

Tabela 4: Custo dos Programas para o Manejo do Parque Estadual de Porto

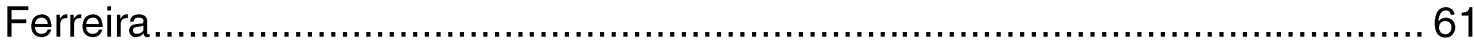

Tabela 5: Custo dos Programas para o Manejo do Parque Nacional do Iguaçu

62

\section{ÍNDICE DE GRÁFICOS}

Gráfico 1: Despesas correntes nas operações do parque 58 


\section{Resumo}

ARAUJO, Renato S. P. A Viabilização de Parques com o Apoio do Turismo - O Caso do Parque Estadual de Campos do Jordão. 2008. $123 \mathrm{f}$. Dissertação (mestrado) - Faculdade de Filosofia, Letras e Ciências Humanas, Universidade de São Paulo, São Paulo, 2008.

O objetivo da pesquisa é analisar o turismo e seus serviços em parques. A necessidade de manutenção dos parques, a precariedade na conservação e a falta de recursos para a instalação de infra-estrutura, deixam os parques em estado de abandono. O turismo, como atividade econômica compatível com a idéia de parque, seja talvez uma das poucas atividades rentáveis para a sustentação destas unidades de conservação, no entanto os parques brasileiros são pouco visitados ou acabam não recebendo parte da receita gerada pela sua existência. Pensando nestes problemas, a pesquisa tem como interesse analisar quais os fatores necessários para uma abertura e exploração turística dos parques, tendo como objeto de investigação o Parque Estadual de Campos do Jordão (PECJ). O PECJ foi escolhido por ser o mais visitado do Estado de São Paulo fora da mancha urbana da capital. Entretanto, o trabalho detectou que o parque tem deficiências de caráter físico relativo aos equipamentos de infra-estrutura que acabam por comprometer a sua visitação. A pesquisa concluiu que uma abertura turística aliada a uma alta qualidade de infra-estrutura pode resultar em uma saída para a conservação dedos parques.

Palavras-chave: Ecoturismo, Parques Estaduais, Planejamento Ambiental, Campos do Jordão, Parque Estadual de Campos do Jordão 
ARAUJO, Renato S. P. A Viabilização de Parques com o Apoio do Turismo - O Caso do Parque Estadual de Campos do Jordão. 2008. $123 \mathrm{f}$. Dissertação (mestrado) - Faculdade de Filosofia, Letras e Ciências Humanas, Universidade de São Paulo, São Paulo, 2008.

The purpose of the present study was to analyze tourism and tourism services in parks. The need to maintain the parks, poor conservation and lack of resources to implement infrastructure have led parks to a status of abandonment. Tourism, as an economic activity compatible with parks, is probably one of the few profitable activities to support these conservation units. However, Brazilian parks are not highly visited and tend to receive a small share of the income generated by their existence. Considering such issues, this study intended to analyze which factors are necessary to open and explore the tourism portion of parks, focusing the investigation on State Park of Campos do Jordao (Parque Estadual de Campos do Jordao - PECJ). PECJ was chosen because it is the most widely visited park in the State of Sao Paulo located outside the capital city urban area. However, our study detected that the park has a number of physical deficits considering infrastructure equipment that may hinder visitation. The study concluded that tourism opening combined with high quality infrastructure may lead to an alternative to park conservation.

Key words: Ecotourism, State Parks, Environmental Planning, Campos do Jordao, Parque Estadual de Campos do Jordao - State Park of Campos do Jordao. 


\section{Introdução}

Atualmente, a preocupação com o meio ambiente é tema de diversas conferências e reuniões entre os governantes do mundo inteiro. As áreas de proteção ao meio ambiente surgiram dessa preocupação do homem em manter preservados muitos dos diferentes ecossistemas existentes na Terra. Pelos mais diferentes motivos, as nações criaram Parques Nacionais: reservas que devem ser preservadas pelo homem, seja por sua beleza natural, sua importância para o ecossistema ou para a biosfera ou para proteger populações tradicionais que têm desaparecido. No entanto, o conceito de parques foi sendo modificado: atualmente, por exemplo, no Brasil, a lei 9.985/2000 - que institui o Sistema Nacional de Unidades de Conservação da Natureza - proíbe as populações tradicionais em Parques.

No Brasil, os primeiros parques nacionais - o de Itatiaia (RJ/MG), o de Iguaçu (PR) e o da Serra dos Órgãos (RJ) - foram criados no final da década de 30. Quase 70 anos depois, existem no Brasil 42 parques, metade deles abertos para visitação.

Segundo o decreto 84.017 de 21/09/1979, Parques Nacionais são reconhecidos como "áreas geográficas extensas e delimitadas, dotadas de atributos naturais excepcionais, objeto de preservação permanente, submetidas à condição de inalienabilidade e indisponibilidade no seu todo. Os parques nacionais destinam-se a fins cientificos, culturais, educativos e recreativos; criados e administrados pelo Governo Federal, constituem bens da União destinados ao uso comum do povo, cabendo às autoridades, motivadas pelas razões de sua criação, preservá-los e mantêlos intocáveis. $O$ objetivo principal do reconhecimento de um parque nacional reside na preservação dos ecossistemas naturais englobados contra quaisquer alterações que os desvirtuem."

O Parque Nacional, segundo a lei 9.985/2000, tem "como objetivo básico a preservação de ecossistemas naturais de grande relevância ecológica e beleza cênica, possibilitando a realização de pesquisas científicas 
e o desenvolvimento de atividades de educação e interpretação ambiental, de recreação em contato com a natureza e de turismo ecológico."

Como podemos observar, os parques nacionais podem existir para os mais diferentes motivos com a finalidade de preservar suas características naturais. O Sistema Nacional de Unidades de Conservação - SNUC - divide as unidades de conservação em dois grupos: as Unidades de Proteção Integral (Estação Ecológica, Reserva Biológica, Parque Nacional, Monumento Natural e Refúgio de Vida Silvestre) e as Unidades de Uso Sustentável (Área de Proteção Ambiental, Área de Relevante Interesse Ecológico, Floresta Nacional, Reserva Extrativista, Reserva de Fauna, Reserva de Desenvolvimento Sustentável e Reserva Particular do Patrimônio Natural).

Segundo Eagles (2004, p.77) o turismo "freqüentemente vem sendo usado como uma estratégia para ganhar apoio público para parques nacionais e áreas protegidas". O turismo aparece atualmente como um dos mais importantes geradores de divisas e empregos no mundo inteiro. $O$ planejamento ligado ao turismo deve fazer parte dos planos de qualquer país (exceto países em guerra). O grande potencial turístico brasileiro diz respeito às suas belezas naturais. Apesar de apresentar importantes lugares turísticos como Ouro Preto (MG), Olinda (PE), Salvador (BA), Rio de Janeiro (RJ), não representam verdadeiros pólos turísticos como os existentes nas cidades norteamericanas, européias e asiáticas. Yázigi (2003, p. 09) lembra que "o Brasil éo país mais enfeado nos últimos sessenta anos", e completa "a feiúra é tal que, salvo restritos casos, e limitados a algumas de suas áreas, já não ousamos recomendar cidades a turistas: recomendamos as belezas naturais que os municípios dispõem". Portanto, os ecossistemas brasileiros apresentam uma riqueza impressionante que deve ser aproveitada.

Porém, na realidade, o que vemos é o quase que total descaso dos governos em criar um plano turístico para aproveitar essas qualidades. Parques nacionais em situações precárias ou de abandono, as lutas por terra, dificuldades de manutenção e legislação pouco cumprida são alguns dos 
desafios que existem para a implantação de um verdadeiro plano turístico para aproveitar esse potencial.

A preocupação com o turismo é algo existente em países europeus desde meados do século XIX. No entanto, o que encontramos no Brasil é uma falta de planejamento espacial do turismo. O planejamento turístico permanece como algo ainda novo e, talvez, pouco compreendido por nossos governantes.

Por fim, sob a ótica de planejamento turístico, podemos citar Yázigi (2003) que tenta trabalhar o planejamento turístico como parte da vida cotidiana, não só em função do turista, mas fazer com que este planejamento enriqueça a vida do morador do local. O turismo acaba sendo encarado como organização e planejamento à vida do país.

Segundo o Yázigi (2003, p. 07), "o planejamento turístico tem como,..., objetivo mor denunciar e dar um basta à degradação ambiental, em suas dimensões da biosfera e do patrimônio ambiental urbano". E mais a frente (2003, p. 16) “...entenda-se, de uma vez por todas, planejamento como processo sem fim".

Ainda, Yázigi (2003, p. 69) trabalha a questão das paisagens e diz que “... ao defender a preservação da paisagem lato senso - natural e urbana penso mormente em sua importância para o habitante do lugar, de quem é tributária e só depois, no turista". Depois, acrescenta que "a paisagem é um dos pilares da idéia de lugar que tanto se busca hoje... A paisagem interessa antes a seus próprios habitantes e que numa relação de estima deles pelo espaço é que, eventualmente, despertará o interesse de transeuntes, visitantes, turistas" (2003, p. 70).

O grande potencial turístico brasileiro encontra-se nas belezas naturais, porém são poucos os estudos sobre o aproveitamento turístico desses parques. A primeira pergunta lançada é sobre a possibilidade de turismo nesses locais. De que forma, os planos de manejo, quando existentes, tratam 
da questão do turismo? Os poucos recursos públicos existentes impedem a criação de uma infra-estrutura básica para o turismo, ou até mesmo, para a manutenção dos parques conforme a lei.

A defesa dos parques estaduais, na pesquisa, deve atender a dois princípios básicos: primeiro como unidades de conservação que são e, segundo como áreas de potencial turístico. Como se sabe, os riscos de invasões e depredações são imensos, principalmente no que se refere ao turismo voltado à natureza. Para isso, como lembram Cabral e Souza (2005, p. 26), "o conhecimento da legislação ambiental é imprescindível, uma vez que é um poderoso instrumento colocado à disposição da sociedade, a fim de que se faça valer o direito constitucionalmente assegurado a todo o cidadão brasileiro de viver em condições dignas em ambiente saudável e ecologicamente equilibrado".

As reservas devem aproveitar sua potencialidade turística oferecendo serviços e equipamentos "obrigatórios" capazes de gerar renda para a viabilização do próprio parque. Afinal, o Brasil possui muitos parques que sequer possuem plano de manejo. Não pensar numa forma de autosustentabilidade econômica equivale à possibilidade de perder os parques.

\subsection{Objetivo geral}

O objetivo principal desta pesquisa é apresentar diretrizes mais consistentes para o aproveitamento turístico do Parque Estadual de Campos do Jordão, fazendo uma análise de sua infra-estrutura e ser uma fonte de referência para a atualização de seu Plano de Manejo, obrigatório segundo o artigo 27 do SNUC. 


\subsection{Objetivos específicos}

Os objetivos específicos desta pesquisa são, a saber:

detectar os principais problemas referentes aos equipamentos do Parque Estadual de Campos Do Jordão (PECJ);

oferecer subsídios para o aumento do fluxo turístico do PECJ e, possibilitar assim, sua auto-sustentabilidade;

avaliar as possibilidades de desenvolver equipamentos e infra-estrutura para a atividade turística no PECJ;

e Discutir a conservação da área de proteção e suas relações com a capacidade de carga.

O capítulo 3 apresenta definições e comentários acerca das áreas protegidas no mundo, no Brasil e no Estado de São Paulo. Além de caracterizar o Instituto Florestal (órgão que administra as Unidades de Conservação estaduais) e o Ecoturismo.

O capítulo 4 apresenta uma revisão bibliográfica acerca da proteção dos parques e tenta responder as seguintes perguntas: por que e para quem os parques foram criados?

O capítulo 5 trata da questão econômica dos parques. Um tema extremamente importante e muitas vezes deixado de lado nas pesquisas sobre o planejamento de parques. A questão do valor e dos custos dos parques é essencial para a sustentabilidade dos mesmos.

O capítulo 6 aborda o planejamento para o turismo em parques, levantando autores e experiências que tratam do assunto no Brasil e no mundo.

O capítulo 7 apresenta algumas experiências do turismo em parques no mundo, especialmente em parques de países em desenvolvimento. A análise 
deve levar a uma comparação com a situação brasileira e, em especial, a do Estado de São Paulo.

O capítulo 8 apresenta o estudo de caso sobre a caracterização do turismo no Parque Estadual de Campos do Jordão. O Parque Estadual de Campos do Jordão foi escolhido por ser, segundo dados de Gallo Junior (2000, p. 158), o segundo parque mais visitado do estado de São Paulo'; e apresentar algumas deficiências relacionadas à visitação pública².

1 O Parque Estadual Alberto Lofgren, com aproximadamente 300 mil visitantes por ano é o mais visitado. Ele não foi o escolhido por estar na capital do estado e assim, pode muitas vezes não ser utilizado como destino turístico.

${ }^{2}$ No ano de 1997, a cidade de Campos do Jordão recebeu mais de três milhões de turistas, no entanto o PECJ recebeu, no mesmo ano, 126.457 visitantes. 


\section{Método e procedimentos técnico-operacionais}

A pesquisa foi desenvolvida em etapas de gabinete e campo onde foram utilizados os seguintes instrumentos de apoio:

1ㄹ Etapa - Gabinete

Mapa das Unidades de Conservação Gerenciadas pelo Instituto Florestal - Instituto Florestal e

Atlas do Plano de Manejo do Parque Estadual de Campos do Jordão.

2- Etapa - Campo

O trabalho de campo foi realizado nos dias:

16 a 18 de setembro de 2005;

25 e 26 de março de 2006;

19 e 20 de agosto de 2006;

10 e 11 de março de 2007 e

27 a 29 de dezembro de 2007.

Durante o trabalho de campo, foi feito um registro fotográfico utilizandose uma máquina fotográfica analógica Nikon FM-10 e máquina fotográfica Digital Sony Cyber-Shot 7.2 megapixels (todas as fotos são do autor do trabalho); além da coleta de folhetos do parque.

Entrevistas com os funcionários do Parque Estadual de Campos do Jordão. 
3ㄹ Etapa - Gabinete

Elaboração e análise das fotos e folhetos obtidos no PECJ.

Confronto entre os dados obtidos e a bibliografia consultada.

Organização do material fotográfico, redação e conclusões e considerações finais. 


\section{Areas protegidas - usos e características}

\section{1 Áreas protegidas no mundo}

Ao contrário do que muitos pensam, a idéia de áreas protegidas precede a criação do Parque Nacional de Yellowstone. A União Internacional para a Conservação da Natureza (IUCN) lembra que o imperador Asoka da Índia, no ano de 252 a.C., baixou um edital para a proteção dos animais, peixes e florestas, sendo provavelmente, o primeiro documento que estabeleceu uma área protegida, como entendemos atualmente (IUCN, 1986, p. 01).

Os dois princípios que regem o conceito de conservação são: a necessidade de planejar o fornecimento de recursos baseando-se em um inventário acurado e a necessidade de tomar atitudes protecionistas para assegurar que tais recursos não se esgotem (IUCN, 1986, p. 01).

Segundo a IUCN (IUCN, 1986, p. 03), áreas protegidas naturais são essenciais para a conservação dos recursos vivos de uma nação, assim assegurando-se três aspectos: amostras representativas de importantes regiões naturais sejam retidas perpetuamente; a diversidade biológica e física seja mantida; e os materiais genéticos selvagens sejam conservados. Pode-se notar a preocupação com a manutenção das regiões naturais para as futuras gerações.

A mesma instituição (IUCN, 1986, p. 03-04), da qual participam mais de quinhentas ONGs e entidades governamentais, lembra que áreas protegidas também contribuem para a conservação dos recursos vivos e para o desenvolvimento sustentável permitindo manter a estabilidade do ambiente da região circunvizinha e desse modo reduzir a intensidade de enchentes e secas, protegendo o solo da erosão e imitando os extremos dos climas locais; manter a capacidade produtiva do ecossistema, assim assegurando a contínua disponibilidade de água e plantas e produtos animais; fornecer oportunidades para pesquisa e monitoramento de espécies selvagens e ecossistemas e suas relações com o desenvolvimento humano; fornecer oportunidades para 
desenvolvimento rural complementar e o uso racional de terras marginais; fornecer bases para recreação e turismo.

O "Guidelines for Protected Areas Management Categories", de 1994 ( $p$. 17-23), a IUCN faz a seguinte divisão de áreas protegidas:

1. Reserva Natural Restrita: área protegida destinada apenas para ciência. Área de terra e/ou mar possuindo algum ecossistema proeminente ou representativo, espécies ou características geológicas ou fisiológicas, disponíveis primeiramente para pesquisa científica e/ou monitoramento ambiental.

2. Área de Região Selvagem: área protegida destinada à proteção da vida selvagem. Grande área de terra e/ou mar, nada ou ligeiramente modificada, retendo suas características e influências naturais, sem habitantes permanentes ou significativos, na qual a proteção e o manejo existem apenas para preservar as condições naturais.

3. Parques Nacionais: área protegida destinada principalmente para a proteção do ecossistema e recreação. Área natural de terra e/ou mar, destinada para (a) a proteção ecológica integral de um ou mais ecossistemas para as atuais e futuras gerações, (b) excluir a exploração ou a ocupação hostil para as razões da designação da área e (c) fornecer uma fundação para oportunidades espirituais, científicas, educacionais, recreativas e de visita, todas devendo ser compatíveis ambientalmente e culturalmente.

4. Monumento Natural: área protegida destinada principalmente para a conservação de características naturais específicas. Área contendo uma ou mais características naturais/culturais as quais são de valor proeminentes ou únicos por causa de sua raridade inerente, representativa ou qualidade estéticas ou de significado cultural. 
5. Área de Manejo de Habitat/Espécies: área protegida destinada principalmente para a conservação através de intervenção de manejo. Área de terra e/ou mar sujeita a intervenção ativa para finalidades de manejo de modo a assegurar a manutenção dos habitats e/ou para encontrar os requerimentos de espécies específicas.

6. Paisagem de Terra ou Mar Protegida: área protegida manejada principalmente para conservação da paisagem e recreação. Área de terra, com costa e mar se apropriado, onde a interação das pessoas e natureza produz uma área de caráter distinto através do tempo, com estética significativa, valores ecológicos e/ou culturais, e por vezes com alta diversidade biológica. Proteger a integridade dessa interação tradicional é vital para a proteção, manutenção e evolução de tal área.

7. Área Protegida de Recursos Manejados: área protegida manejada principalmente para o uso sustentável do ecossistema natural. Área contendo predominantemente sistemas naturais não modificados, gerenciados para assegurar a proteção a longo prazo e a manutenção da diversidade biológica, enquanto fornece ao mesmo tempo um fluxo natural de produtos e serviços necessários a comunidade.

Atualmente, com exceção dos Parques Nacionais, as outras áreas compõem $60 \%$ de todas as áreas protegidas do planeta. Os Parques Nacionais compõem $22,7 \%$ do total de áreas protegidas, totalizando quase $12 \%$ da superfície da Terra (Quammen, 2006). No entanto, Terborgh \& Schaik (2002, p. 25) afirmam que "a proteção real e formal só foi conseguida para cerca de $5 \%$ da Terra", mas no mínimo $80 \%$ dos governos do mundo assumiram a obrigação de criarem áreas protegidas legalmente. O mapa apresentado na figura 1, apresenta as áreas protegidas no mundo. 
Figura 1: Áreas protegidas no mundo

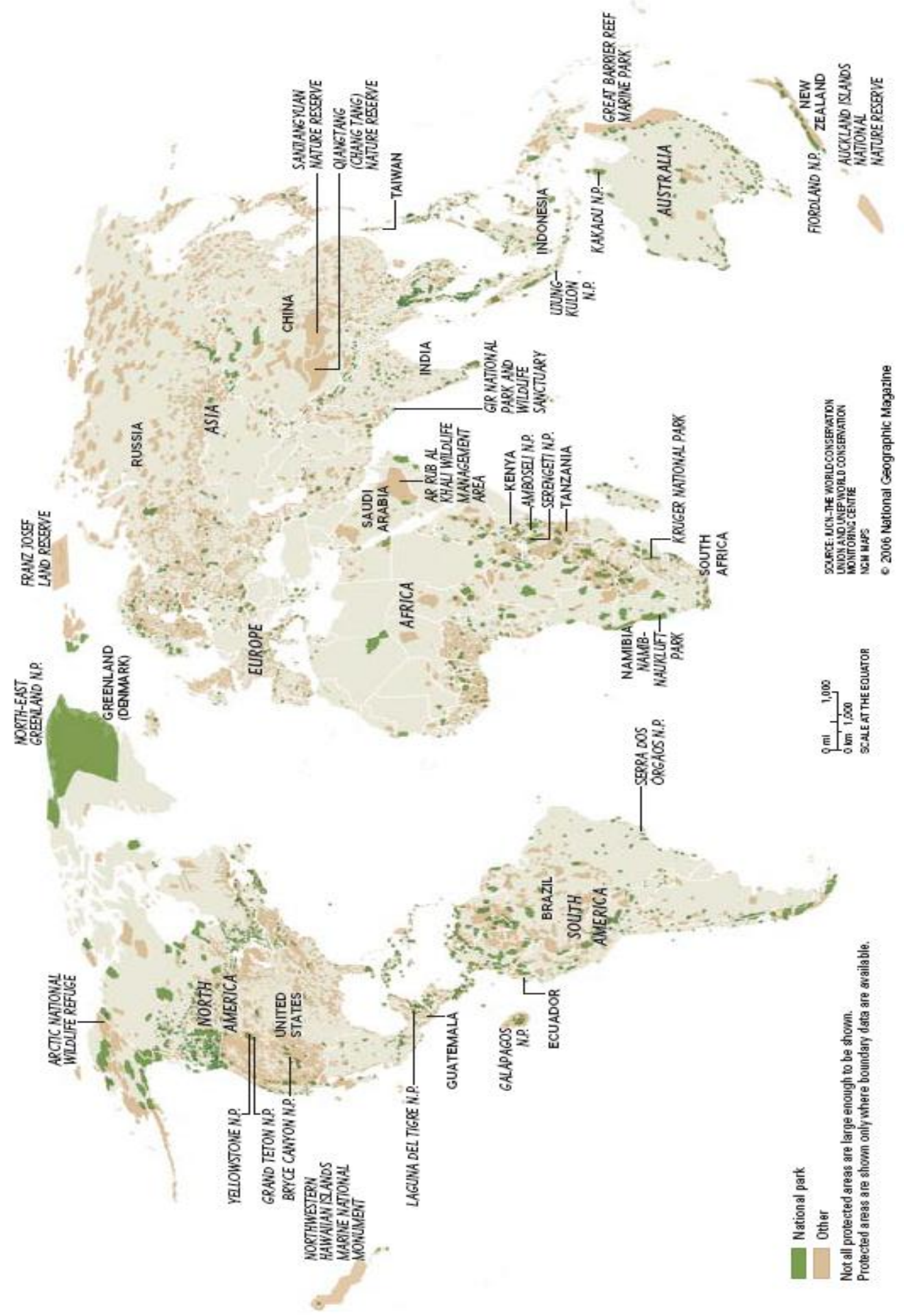

Fonte: National Geographic (outubro/2006: 64-65) 
Dentre os numerosos usos que podemos encontrar nos Parques, o turismo é destaque e tema de diversos debates.

Nos mais diversos países, o turismo em parques é prática corrente há décadas. Nos Estados Unidos, segundo Terborgh (2002, p. 30), os parques nacionais "atraem um público ávido para usufruir do cenário, da vida selvagem e das atividades recreacionais". O autor lembra que instalações como centro de informações, sanitários, restaurantes e acomodações para pernoite, excursões por trilhas e caminhadas, e estruturas para acampamentos, além de um corpo de pessoal são fatores importantes para atrair o público.

Terborgh lembra que os benefícios derivados da conservação da natureza "são intangíveis e estão relacionados com recreação, bem-estar físico e o valor intrínseco da própria natureza" (2002, p. 33). Contudo, o autor (2002, p. 33) anota que "praticamente em todos os parques dos Estados Unidos existe uma história de oposição, protestos, menosprezo e pressões políticas" e "o apoio popular para um parque só começa a se fazer sentir depois que o parque existe, não obstante o quão fantástico seja o cenário ou abundante a vida selvagem". E ainda lembra que "o valor que os parques nacionais nos Estados Unidos têm para sua população é sugerido pelo valor do orçamento que os sustenta - cerca de US\$ 2,4 bilhões em 2001" (2002, p. 31). E quando se trata da opinião dos cidadãos norte-americanos sobre diversas instituições nacionais, o Serviço de Parques Nacionais está entre as primeiras, com mais de $90 \%$ de aprovação. Não foi encontrado nenhum tipo de pesquisa sobre a aprovação da população em relação ao IBAMA.

\subsection{Areas protegidas no Brasil - as unidades de conservação}

O Brasil, com uma área de cerca de 8,5 milhões de $\mathrm{km}^{2}$, talvez seja o país que, individualmente, possui a maior diversidade de espécies do mundo. No entanto, segundo Morsello (2001, p. 45-46) a importância do país no contexto mundial da diversidade biologia não se reflete, entretanto, na superfície protegida em UCs públicas. Segundo a autora, "embora não existam estimativas exatas, a somatória das áreas protegidas em nível federal está por 
volta de $3,7 \%$ da superfície do país, bastante abaixo da média latino americana de 6\%".

Em 18 de Julho de 2000, foi aprovada a lei no 9.985, ou Sistema de Unidades de Conservação - SNUC - que "estabelece critérios e normas para a criação, implantação e gestão das unidades de conservação".

O SNUC (Brasil: 2000) define unidade de conservação como "espaço territorial e seus recursos ambientais, incluindo as águas jurisdicionais, com características naturais relevantes, legalmente instituído pelo Poder Público, com objetivos de conservação e limites definidos, sob regime especial de administração, ao qual se aplicam garantias adequadas de proteção."

A lei também faz uma importante categorização das Unidades de Conservação, dividindo-as em dois blocos:

1. Unidades de Proteção Integral - preservar a natureza, sendo admitido apenas o uso indireto dos seus recursos naturais.

2. Unidades de Uso Sustentável - compatibilizar a conservação na natureza com o uso sustentável de parcela dos seus recursos naturais.

As Unidades de Proteção Integral são:

Estações Ecológicas, nas quais o objetivo é a preservação da natureza e a realização de pesquisas científicas, com visitação proibida;

Reservas biológicas, criadas com o objetivo de preservação da biota e demais atributos naturais existentes em seus limites, sem interferência humana direta ou modificações ambientais, excetuando-se as medidas de recuperação de seus ecossistemas alterados e as ações de manejo que são necessárias para recuperar e preservar o equilíbrio natural, a 
diversidade biológica e os processos ecológicos naturais, também com visitação proibida;

Parques, cujo principal objetivo é a preservação de ecossistemas naturais de relevância ecológica e beleza cênica, possibilitando ainda a realização de pesquisas científicas e o desenvolvimento de atividades de educação e interpretação ambiental, de recreação em contato com a natureza e de turismo ecológico. Nos parques, a visitação pública é permitida;

Monumentos naturais, cujo objetivo básico é preservar sítios naturais raros, singulares ou de grande beleza cênica, de visitação permitida e,

Refúgio da vida silvestre, que tem como objetivo proteger ambientes naturais onde se asseguram condições para a existência ou reprodução de espécies ou comunidades da flora local e da fauna residente ou migratória.

As Unidades de Uso Sustentável são:

Área de Proteção Ambiental (APA) constitui-se em uma área extensa, com um certo grau de ocupação humana, dotada de atributos abióticos, bióticos, estéticos ou culturais especialmente importantes para a qualidade de vida e o bem-estar das populações humanas e tem como objetivos básicos proteger a diversidade biológica, disciplinar o processo de ocupação e assegurar a sustentabilidade do uso dos recursos naturais;

Área de Relevante Interesse Ecológico (ARIE) é uma área em geral de pequena extensão, com pouca ou nenhuma ocupação humana, com características naturais extraordinárias ou que abriga exemplares raros da biota regional, e tem como objetivo manter os ecossistemas naturais de importância regional ou local e regular o uso admissível dessas 
áreas, de modo a compatibilizá-lo com os objetivos de conservação da natureza;

Floresta Nacional (FLONA) é uma área com cobertura florestal de espécies predominantemente nativas e tem como objetivo básico o uso múltiplo sustentável dos recursos florestais e a pesquisa científica, com ênfase em métodos para exploração sustentável de florestas nativas;

Reserva Extrativista é uma área utilizada por populações extrativistas tradicionais, cuja subsistência baseia-se no extrativismo e, complementarmente, na agricultura de subsistência e na criação de animais de pequeno porte, e tem como objetivos básicos proteger os meios de vida e a cultura dessas populações, e assegurar o uso sustentável dos recursos naturais da unidade.

Reserva de Fauna é uma área natural com populações animais de espécies nativas, terrestres ou aquáticas, residentes ou migratórias, adequadas para estudos técnico-científicos sobre o manejo econômico sustentável de recursos faunísticos.

Reserva de Desenvolvimento Sustentável é uma área natural que abriga populações tradicionais, cuja existência baseia-se em sistemas sustentáveis de exploração dos recursos naturais, desenvolvidos ao longo de gerações e adaptados às condições ecológicas locais e que desempenham um papel fundamental na proteção da natureza e na manutenção da diversidade biológica.

Reserva Particular do Patrimônio Natural (RPPN) é uma área privada, gravada com perpetuidade, com o objetivo de conservar a diversidade biológica.

O SNUC representa um importante avanço nas definições e objetivos das áreas protegidas. 
Em relação aos domínios, o Amazônico é aquele melhor protegido, sendo a Caatinga e o Cerrado aqueles em que há a maior deficiência em unidades instituídas (Morsello, 2001, p. 47). Vale lembrar que tanto a Caatinga como o Cerrado não são citados na Constituição Federal.

No país, Terborgh (2002, p. 30) afirma existirem mais 'parques de papel' do que verdadeiros guarda-parques na Amazônia. Segundo ele, o país ainda permanece com uma mentalidade de avanço de fronteiras e a atitude "o diabo que fique com o que sobrar" que a acompanha. 




Figura 2: Parques Nacionais no Brasil 


\subsubsection{Parques Estaduais do Estado de São Paulo}

Apesar da importância que encontramos na definição mundial e federal sobre os parques nacionais, neste trabalho utilizaremos as definições estabelecidas pela lei paulista. Em que pese ser uma definição mais antiga, como nosso estudo de caso será de um Parque Estadual paulista, devemos levar em consideração a lei que rege este parque. No entanto, tendo em vista as definições da IUCN e do SNUC, estas serão sempre lembradas para quaisquer críticas em relação à lei estadual. Vale lembrar também que o resultado da pesquisa deve servir não apenas ao planejamento dos parques estaduais, mas também aos dos parques nacionais, portanto, em diversos momentos confrontaremos a lei federal e a lei estadual.

Segundo Brito (2000, p. 115), as unidades de conservação no estado de São Paulo somam 851.547,94 hectares (aproximadamente 3\% da área do estado). O Horto Botânico foi a primeira dessas unidades, instalado em 1896, na zona norte da capital paulista, por iniciativa de Albert Loëfgren.

O decreto estadual $n^{\circ}$ 25.341, de 4 de junho de 1986 estabelece o regulamento dos Parques Estaduais Paulistas. Segundo o decreto, o objetivo principal dos parques estaduais "reside na preservação dos ecossistemas englobados contra quaisquer alterações que os desvirtuem". Eles se destinam a "fins científicos, culturais, educativos e recreativos". O decreto define como Parques Estaduais "as áreas que atendam às seguintes exigências:

1. contenham um ou mais ecossistemas totalmente alienados ou parcialmente alterados pela ação do homem, nos quais as espécies vegetais e animais, ou seres geomorfológicos e os "habitats" ofereçam interesse especial do ponto de vista científico, cultural, educativo e recreativo, ou onde existam paisagens naturais de grande valor cênico;

2. tenham sido objeto, por parte do Estado, de medidas tomadas para impedir ou eliminar as causas das alterações e para proteger efetivamente os fatores biológicos, geomorfológicos ou técnico que determinaram a criação do Parque Estadual; 
3. condicionem a visitação pública a restrições específicas, mesmo para propósitos científicos, culturais, educativos ou recreativos.

Sobre a administração dos Parques, segundo o decreto, "serão administrados pelo Instituto Florestal - IF" que deve elaborar um Plano de Manejo e submetê-lo à aprovação do Conselho Estadual do Meio Ambiente CONSEMA.

O plano de manejo deve indicar, segundo o decreto, "detalhadamente o zoneamento de áreas total do Parque Estadual que poderá, conforme o caso, conter no todo, ou em parte, as seguintes zonas características:
I. Zona Intangível
II. Zona Primitiva
III. Zona de Uso Extensivo
IV. Zona de Uso Extensivo
V. Zona Histórico-Cultural
VI. Zona de Recuperação
VII. Zona de Uso Especial

Para a pesquisa, muito nos interessa a Zona de Uso Intensivo, que segundo o decreto "é aquela constituída por áreas naturais ou alteradas pelo homem. $\mathrm{O}$ ambiente é mantido o mais próximo possível do natural, devendo conter: centro de visitantes, museus, outras facilidades e serviços. O objetivo geral do manejo é o de facilitar a recreação intensiva e educação ambiental em harmonia com o meio".

Segundo o artigo 35 do decreto paulista, "sempre que possível, os locais destinados a acampamento, estacionamento, abrigo, restaurante e hotel localizar-se-ão fora do perímetro dos Parques Estaduais". No entanto, o parágrafo primeiro lembra que "sempre que absolutamente necessária, com o fim de proporcionar ao público maiores oportunidades de apreciar e de se beneficiar dos valores dos Parques Estaduais, a localização dessas facilidades, 
dentro dos seus limites, restrigir-se-á às Zonas de Uso Intensivo, nas condições previstas no Plano de Manejo".

O entendimento de tal artigo é essencial para a nossa pesquisa. Afinal, para "proporcionar ao público maiores oportunidades de apreciar e de se beneficiar dos valores dos Parques Estaduais" pode dar a abertura necessária para a construção de uma série de benefícios para os usuários dos parques. No capítulo 4, esta questão será aprofundada.

Vale lembrar, no entanto que o SNUC é quem determinar as funções e zoneamentos dos Parques como Unidades de Conservação. 
Figura 3: Unidades de Conservação Gerenciadas pelo Instituto Florestal

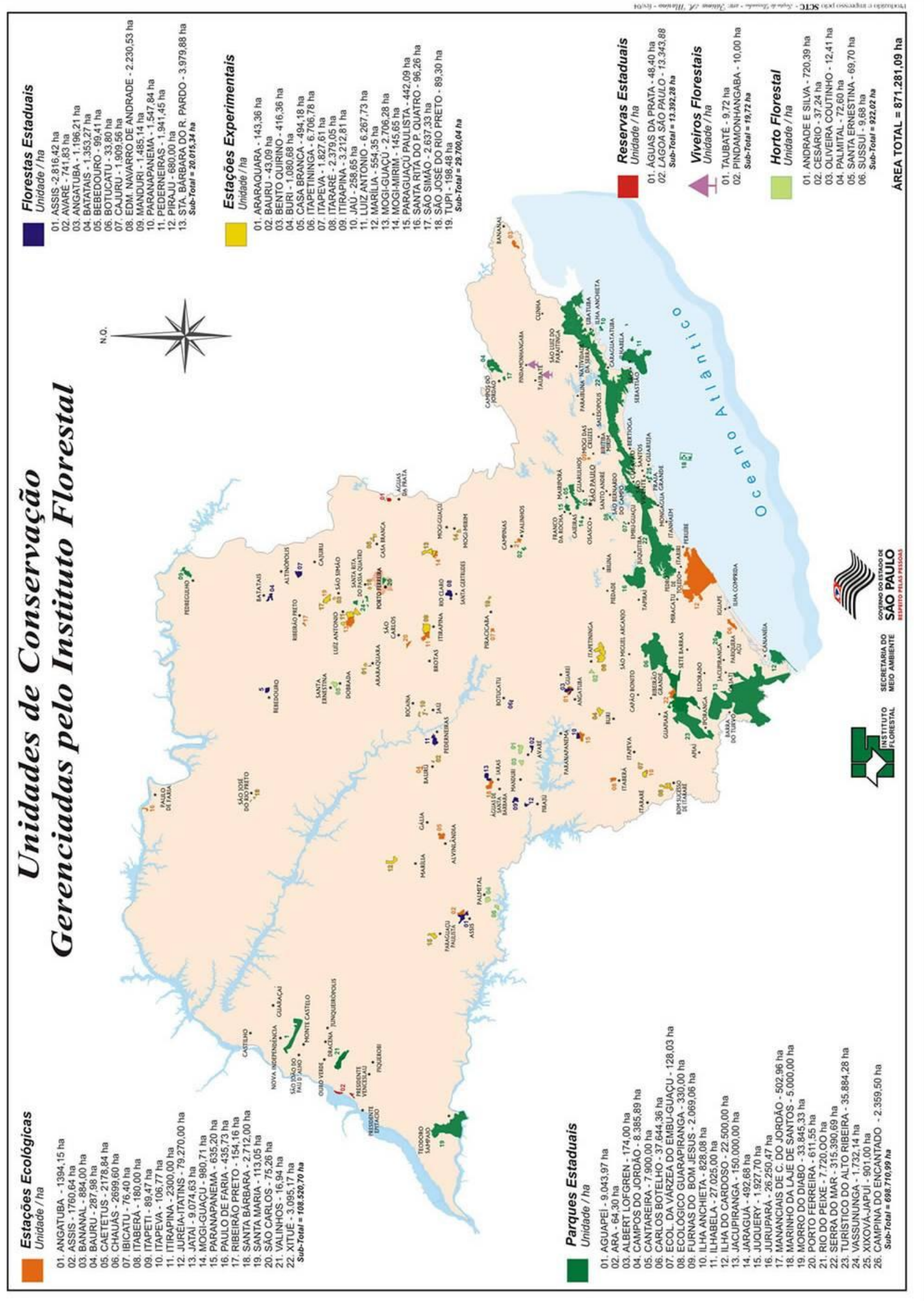




\subsubsection{O Instituto Florestal}

O Instituto Florestal foi criado em 1886 e é uma referência respeitada na área de conservação da biodiversidade (Brito, 2000, p. 132). O decreto no 52.370/70 conferiu ao Instituto as seguintes atribuições:

- realizar pesquisa e experimentação sobre espécies florestais de importância econômica;

- estudar e desenvolver técnicas silviculturais para as diversas regiões ecológicas do Estado;

- intervir no setor florestal, detendo o domínio da florestas de preservação permanente, e efetuar reflorestamento como empresário florestal, com fin conservacionistas, técnicos e econômicos, de acordo com o plano previamente aprovado;

- estudar, propor e executar medidas de conservação e de exploração racional e econômica de florestas;

- realizar investigação sobre a biologia da fauna silvestre, especialmente de animais de caça, e de suas relações com o ambiente florístico;

- promover estudos sobre paisagismo e o aproveitamento de áreas florestais de responsabilidade do Estado, para fins educacionais e recreativos;

- manter e desenvolver o Museu Florestal Estadual;

- aperfeiçoar seu corpo técnico, promovendo cursos e estágios de treinamento, em estabelecimentos nacionais e estrangeiros;

- divulgar conhecimentos científicos, a experiência técnica e os resultados dos trabalhos realizados no Instituto e

- estabelecer intercâmbio com instituições congêneres do país e do exterior.

A divisão responsável pela gestão das Unidades de Conservação é a Divisão de Reservas e Parques (DRPE), que, segundo o mesmo decreto, tem as seguintes funções: cadastrar todas as florestas artificiais e propriedade do Estado; desenvolver projetos de pesquisa e experimentação das seções técnicas do Instituto; promover a conservação e a exploração racional e 
econômica das reservas florestais do Estado e; executar trabalhos visando a utilização dos parques estaduais para finalidades educacionais, recreativas e científicas.

As pesquisas realizadas nas Unidades de Conservação devem ser aprovadas pela Comissão Técnico Científica (COTEC). É um duro processo burocrático que leva de 30 a 120 dias. Segundo Nilse Yokomizo, citada pela pesquisadora Paula Felicio Drummond de Castro, tal demora ocorre porque "muitas vezes é penoso juntar todos os membros da Comissão para darem o parecer da pesquisa". (DRUMMOND, 2004, p. 71) Segundo Castro, o "termo de compromisso" e o "termo de responsabilidade" para a pesquisa, reforçam o compromisso do pesquisador em divulgar para o IF os resultados da pesquisa. Em entrevista a pesquisadora, Antonio Modesto Pereira, funcionário do Parque Estadual Turístico do Alto Ribeira (PETAR), afirma que: "a gente está aqui, o pesquisador solicita a pesquisa porque quer, principalmente as que são feitas por universidades. Ele quer desenvolver o trabalho em cima daquilo que ele está estudando. Então, ele manda para gente a pesquisa que ele quer desenvolver e como é de praxe, o Instituto Florestal não nega nenhuma pesquisa. Seja lá para dar algum subsídio para a Unidade ou não. Não se nega. Seria interessante a gente pegar a pesquisa que desse algum retorno para o parque. Lógico, quase todas dão retorno, de alguma forma ela vai servir, mas tem algumas pesquisas que a gente não sabe se vai servir ou não". (DRUMMOND, 2004, p. 82)

O Instituto Florestal é o órgão responsável pela manutenção do Parque Estadual de Campos do Jordão. Apesar de diversos serviços serem - como veremos no capítulo 6 - terceirizados, o órgão tem autonomia para administrar a área. 


\subsection{Ecoturismo ou Turismo de Natureza}

Cada vez mais, nas diversas regiões do planeta, a questão do turismo vem sendo motivo de estudos e discussões, nos diferentes setores da sociedade: nos governos, nas academias e por parte da iniciativa privada e do Terceiro Setor. Héctor Ceballos-Lascuráin (1995, p. 25) lembra que o turismo é "a indústria civil mais importante do mundo e maior do que a do automóvel, do aço, da eletrônica ou da agricultura". Vale ressaltar que a indústria pressupõe, segundo o Houaiss, uma atividade econômica que tem por fim a manipulação e a exploração de matérias-primas e fontes energéticas transformados em produtos semi-acabados ou em bens de produção e de consumo.

Segundo Lage (2004, p. 17) o desenvolvimento do turismo pode ser explicado pelos seguintes fatores: o aumento da população, a urbanização, a industrialização, a expansão de negócios, a maior disponibilidade de renda, a ampliação do tempo livre e os avanços tecnológicos, dentre os quais a autora destaca os meios de comunicação, de informática e de comercialização de bens e serviços turísticos. No Brasil, não podemos nos esquecer da Consolidação das Leis do Trabalho que garantiu férias aos trabalhadores. Para Doris Ruschmann (2005, p. 13), o turismo evoluiu principalmente após a Segunda Guerra Mundial, como "conseqüência dos aspectos relacionados à produtividade empresarial, ao poder de compra das pessoas e ao bem-estar resultante da restauração da paz no mundo".

Filion, Foley e Jacquemot lembram (1994, p.236) que o termo ecoturismo foi originalmente cunhado em 1987 por Héctor Ceballos-Lascuráin, no México, e, por causa do seu apelo, obteve um grande uso desde sua introdução. Ele originalmente definiu ecoturismo como "viajar para áreas naturais relativamente sem distúrbios ou não contaminadas com o objetivo específico de estudar, admirar, e aproveitar o cenário e suas plantas e animais selvagens assim como qualquer manifestação cultural".

Segundo os autores (Filion, Foley e Jacquemot, 1994, p. 239), a magnitude do ecoturismo global é de aproximadamente, dependendo da 
região, algo em torno de $40-60 \%$ do turismo internacional. O turismo de vida selvagem aparece em torno de $20-40 \%$ do turismo internacional.

Segundo David A. Fennell, do Departamento de Estudos em Recreação e Lazer da Universidade Brock (Canadá), a dificuldade de que uma definição para o turismo, uma das maiores 'indústrias' e normalmente associada com diversos dos principais setores da economia mundial, reside no fato de qualquer significado corre o risco de superestimar ou subestimar essa atividade econômica. Um exemplo, segundo o autor, seria considerar todas as vendas de restaurantes como viagem e turismo: o resultado irá artificialmente inflacionar as vendas para os não-turistas (1999, p. 02-03). Mas excluindo todas as vendas, seria igualmente irreal. O autor lembra que "é essa relação com outras disciplinas, por exemplo, a psicologia, a sociologia, a antropologia, a geografia e a economia, que definiu a complexidade do turismo".

Por fim, o autor (Fennell, 1999, p. 04) define turismo como:

"Um sistema de inter-relações que inclui turistas e os serviços associados que providenciam e são usados (instalações, atrações, transporte e acomodação) para ajudar nos deslocamentos, enquanto o turista, como estabelecido pela Organização Mundial do Turismo, é definido como uma pessoa viajando por lazer por um período de no mínimo uma noite, mas não mais que um ano para turistas internacionais e seis meses para pessoas viajando no seu próprio país, sendo que a principal motivação da visita deve ser outra do que ocupar-se em atividades para remuneração nos locais visitados."

Leiper (apud Fennell, 1999, p. 03) considera o turismo como um sistema aberto de cinco elementos interagindo com ambientes extensos: o elemento humano dinâmico, uma região geradora, uma região de trânsito, uma região de destino e a indústria do turismo. 
A economista Beatriz Lage (2004, p. 16-18) assinala que "os deslocamentos temporários de alguns indivíduos do lugar de moradia para outra localidade, devido aos mais diversos motivos,..., já caracterizavam o turismo. Embora o nome ainda não fosse esse, o sentido era o mesmo com maior ou menor intensidade em todas as sociedades". A autora também lembra já no final do século XIX, as mídias impressas começam a anunciar cidades de destaques ou anúncios de hotéis. Finalmente, em 1920, surge a Organização Mundial de Turismo - OMT e, setenta anos depois, o Conselho Mundial de Viagens e Turismo - WTTC, órgãos que tem por finalidade divulgar os dados e estudos sobre o turismo no mundo. $O$ entanto, cabe lembrar que a autora está considerando praticamente todo tipo de deslocamento como turismo e, uma migração de moradia não pode ser considerada desta forma.

Segundo a OMT (Fennell, 1999, p. 162), o turismo internacional deve passar de um bilhão de pessoas em 2010. Ao mesmo tempo, os ganhos com o turismo internacional devem passar de US\$1.5 trilhões. Assim, comumente diversos autores (Lage, Fennell, Ruschmann) afirmam que tal "indústria" é a maior do mundo.

O ecoturismo, segundo Fennell (1999, p. 30), é uma extensão do chamado Turismo Alternativo. Segundo o autor, o ecoturismo vem crescendo como uma conseqüência da insatisfação com formas convencionais de turismo que tem, no senso comum, ignorado elementos sociais e ecológicos de regiões estrangeiras em favor de um turismo mais antropocêntrico.

Segunda a Embratur (2002, p. 02), ecoturismo é o "segmento da atividade turística que utiliza, de forma sustentável, o patrimônio natural e cultural, incentiva sua conservação e busca a formação de uma consciência ambientalista através da interpretação do ambiente, promovendo o bem-estar das populações envolvidas". No entanto, o texto não esclarece o que seria "forma sustentável", termo utilizado com freqüência, mas pouco esclarecido. Seria, portanto, discutível tal postulado, uma vez que nem sempre o ecoturismo pode promover o bem-estar da população. 
Segundo Kinker (2002, p. 19) o que diferencia ecoturismo dos demais segmentos do turismo de natureza é a aplicação de princípios e valores éticos, o comportamento do turista, o conceito de sustentabilidade com desenvolvimento e o aspecto educacional. A autora lembra que "como qualquer outro segmento do turismo, o ecoturismo gera impactos que precisam de manejo para ser evitados. Um dos objetivos do manejo é controlar a interação homem/natureza, de modo que o meio ambiente não sofra impactos negativos e o turista tenha não só uma experiência agradável, mas seja levado, por meio da interpretação da natureza e do lazer dirigido, a incorporar mudanças de atitudes e comportamentos". (2002, p. 30)

Boyd (2000, p. 174-175) lembra que nem todos os tipos de turismo alternativos, incluindo o ecoturismo, devem ser vistos como totalmente sustentáveis. O diagrama a seguir demonstra tal conceito:

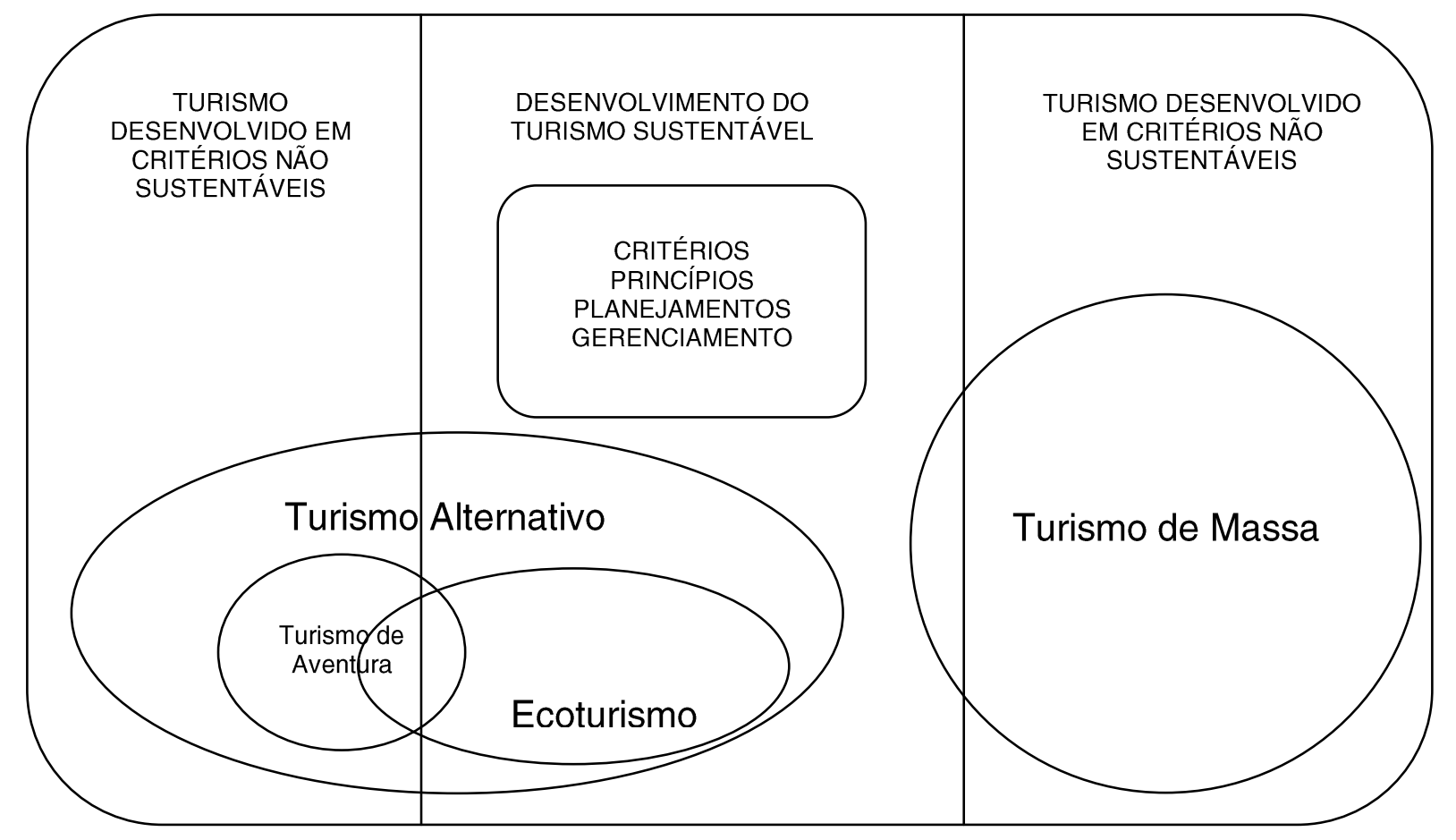

Fonte: Adaptado de Boyd (2000, p. 175)

Stephen BOYD ainda afirma (2000, p. 176) que os critérios do desenvolvimento do turismo sustentável devem ter como princípios: a ética, a eqüidade, a manutenção do uso relativo de capacidade de carga e a promoção de um foco baseado na conservação. O planejamento deve ser pautado pelo 
longo prazo, o proativo ao invés do reativo, a interação ao invés da separação e o encorajamento do envolvimento local. $\mathrm{O}$ gerenciamento tem que assegurar a prestação de contas e responsabilidades por ações tomadas, o foco na interdisciplinaridade e a integração com outras estratégias de gerenciamento para a região ao redor.

Segundo Davenport, et al. (2002, p. 305), o ecoturismo é "freqüentemente saudado como um dos poucos exemplos indiscutíveis de desenvolvimento sustentável que funciona, porque não apenas ajuda a assegurar a preservação in situ das áreas selvagens".

Os autores lembram que uma parte relativamente importante da geração de renda para países tropicais em desenvolvimento provém do ecoturismo, afinal essas rendas dependem muito do "retorno derivado de seus recursos naturais (Davenport, et al., 2002, p. 305)". Para os autores, a definição funcional de ecoturismo é a "visitação aos parques baseada na natureza, que é compatível com a conservação da biodiversidade e que promove a aceitação de longo prazo da unidade de conservação como uma instituição legítima". Nota-se que os autores fazem uma ressalva muito importante, afirmando que ecoturismo não é uma panacéia para todos os males que afligem as nações em desenvolvimento mesmo tendo uma taxa de crescimento anual de $12,5 \%$ ao ano (2002, p. 306).

Davenport et. al. afirmam (2002, p. 305) que "o ecoturismo ajuda a educar o público em geral com relação a questões conservacionistas e cria uma aliança natural entre negócios e conservação, na defesa por um melhor manejo das áreas protegidas".

As principais críticas ao ecoturismo, segundo Davenport et. al. (2002: p. 307), são: 
O turismo não regulamentado causa degradação às áreas naturais que ele diz auxiliar, necessitando de um plano que defina o sistema de zoneamento, a capacidade de carga e os Limites Aceitáveis de Câmbio - LAC;

As agências de manejo de parques que não são capazes de manejar eficazmente o turismo, sendo necessário diversificar a estrutura de ecoturismo - em muitos parques, os visitantes são obrigados a escolher entre padrões mais baixos do que os desejados ou acomodações de luxo com preços altos, desencorajando visitas longas;

$\mathrm{Na}$ maioria das áreas protegidas, as rendas obtidas com o turismo não cobrem os custos de manejo, podendo ser aplicada uma variedade de taxas, otimizando-as para garantir o retorno econômico a partir dos parques;

Mesmo que as rendas obtidas com o ecoturismo sejam divididas com os residentes locais, as quantidades raramente são suficientes para cobrir os custos de oportunidade ou para parar com a retirada ilegal de produtos e a invasão, necessitando uma compensação pela perda do acesso aos recursos do parque ou por prejuízos causados pela vida selvagem originária do parque;

Noção de que os parques são apenas para turistas estrangeiros ricos causa ressentimento entre os residentes locais pobres, tornando necessário um programa de encorajamento do turismo doméstico;

Ecoturismo não é bem sucedido em florestas tropicais, porque lá a vida selvagem é difícil de ser observada e prevalecem condições desconfortáveis e perigosas, sendo necessário um programa de interpretação e investimentos em educação do público.

Para Davenport, et. al., para cada problema enfrentado, existem "ferramentas de Ecoturismo". Para cada ferramenta, eles listam o responsável; os requerimentos para o Melhor Uso; os componentes ideais; as vantagens e 
desvantagens para a Conservação, para os visitantes e para o Manejo (2002, p. 308-315).

Deve-se destacar que o ecoturismo também não é bem sucedido em áreas como a Caatinga ou Desertos.

Dentre as ferramentas apresentadas pelos autores (2002, p. 308-330), se destacam:

\section{Partilha de Renda}

A renda gerada pelo Ecoturismo em parques deve ser partilhada com comunidades locais que demandam compensação pela perda de acesso aos recursos do parque (por exemplo, a lenha ou material de construção). Os autores apontam que tal partilha pode aumentar o apoio público para os parques, especialmente onde estes e as comunidades locais estejam em conflito. No entanto, nos três exemplos africanos utilizados pelos autores (Bundu Safári, Paul Olivier Safári e Dorobo Safári), observamos mais críticas do que acertos nos projetos, porém lembra que "os programas de partilha de renda com prazo indefinido são cheios de ciladas e poderiam ser procurados outros meios de alcançar as metas econômicas e de desenvolvimento. $\boldsymbol{A}$ partilha de renda direta para o desenvolvimento local é de um modo geral a opção menos manejável, eficaz e eqüitativa". (2002, p. 327)

A partilha de renda deve ser repensada,

Ainda sobre as comunidades locais, um outro autor, Sanjay K. NEPAL (2000, p. 75) desenhou um esquema demonstrando as interações entre turismo, parques nacionais e comunidades locais: 


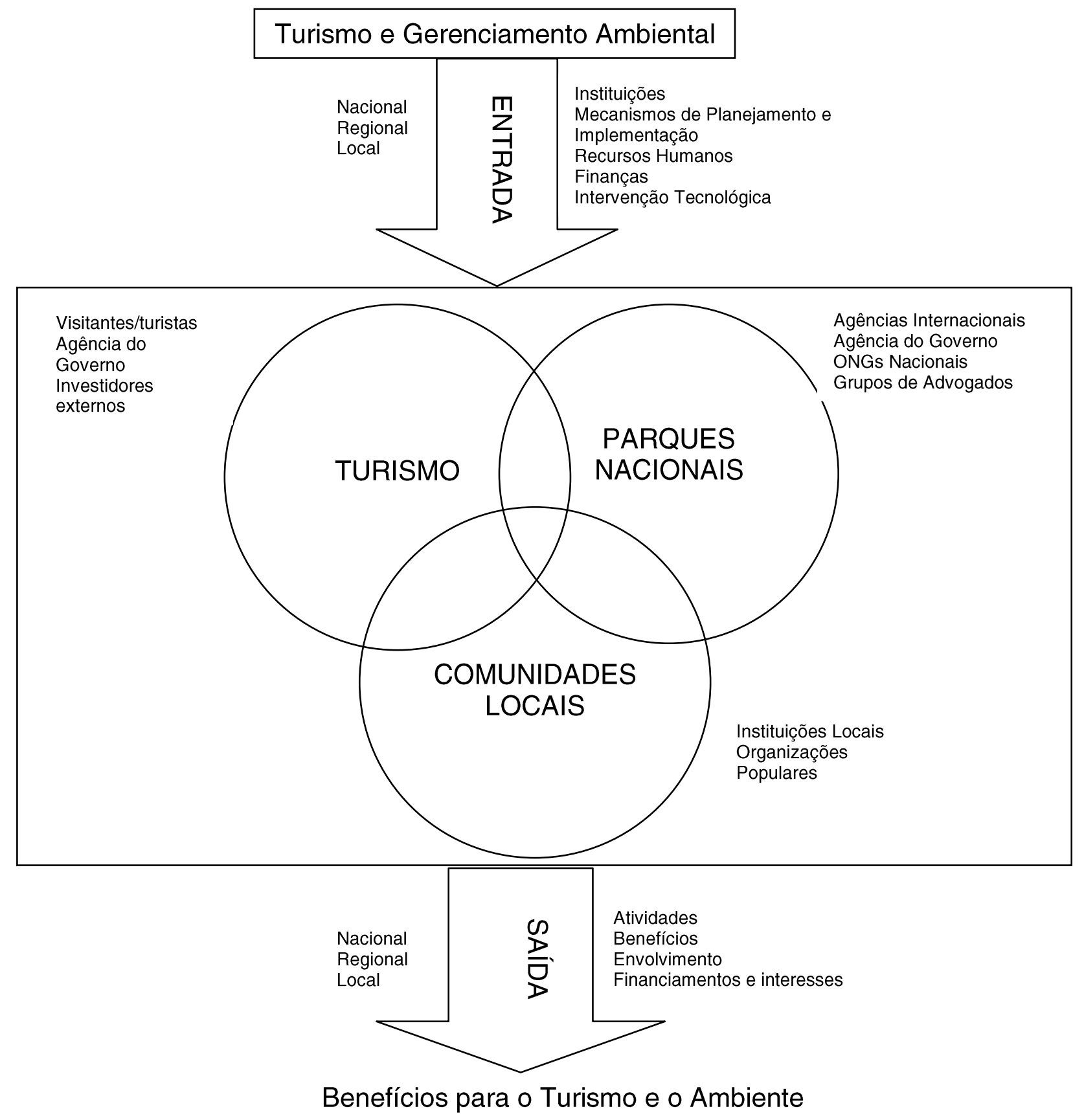

Fonte: Adaptado de NEPAL (2000, p. 75)

\section{Sistemas de zoneamento}

O plano de zoneamento de um parque é "um dos passos iniciais mais importantes para implementar o parque como um todo e o manejo do turismo". Defendem que os recursos do parque, como espécies-bandeira, 
paisagens cênicas, habitats naturais, infra-estrutura etc. podem ser avaliados considerando-se sua situação, originalidade, fragilidade e natureza e grau de ameaças. Lembram que o zoneamento "deve ser completado cedo no desenvolvimento do parque, preferivelmente (ou obrigatoriamente) antes que os principais investimentos em infra-estrutura tenham sido feitos." (2002, p. 316-317).

O zoneamento é item exigido, pela lei $9.985 / 2000$, no Plano de Manejo. Segundo o Sistema Nacional de Unidades de Conservação, zoneamento "é definição de setores ou zonas em uma unidade de conservação com objetivos de manejo e normas específicos, com o propósito de proporcionar os meios e as condições para que todos os objetivos da unidade possam ser alcançados de forma harmônica e eficaz".

\section{Capacidade de Carga}

Os estudos para determinar a capacidade de carga nos parques têm sido considerados "como a cura universal para o seu manejo de visitantes". Afinal, esses estudos podem definir o número máximo de visitantes e comportamentos que uma unidade de conservação pode receber, sem sofrer degradação. No entanto, lembram que a metodologia de capacidade carga "é especifica demais para determinados locais, não oferecendo uma aplicabilidade mais geral e as metas desejáveis podem ser alcançadas mais freqüentemente pela aplicação do senso comum ou de técnicas de manejo adaptativo". (2002, p. 318)

Davenport, et. al. (2002, p. 309) afirmam que a capacidade de carga é de responsabilidade do administrador do parque; deve ser analisada de sítio a sítio; necessita de uma boa compreensão dos aspectos mais frágeis; é usualmente menos ligada às necessidades da biologia do que às de manejo; é impossível determinar a capacidade biológica de carga de modo completo e objetivo; pode resultar em insatisfação do visitante pela limitação do acesso; pode favorecer o acesso a grupos turísticos maiores, onde se requeira reservas 
prévias; pode definir a real capacidade de manejo; é simples de cumprir; freqüentemente resulta em sistemas de reservas e de proteção pobremente implementados; e pode gerar pressões políticas para aumentar a capacidade de carga acima dos limites recomendados.

Os autores concluem afirmando (Davenport, et. al., 2002, p. 330-31) que "o ecoturismo é uma indústria global que vem crescendo rapidamente, com grande potencial para gerar rendas para os países em desenvolvimento e para chamar a atenção pública sobre o valor da conservação. A principal preocupação do manejo de áreas protegidas deveria ser promover atividades educativas e recreações entre os habitantes do próprio país, incluindo aldeões pobres, crianças em idade escolar e as classes mais favorecidas". E lembram que o ecoturismo é apenas um subitem dentre as ferramentas de manejo dos parques e sua implementação pode melhorar essas unidades de conservação por assegurar metas para os parques; identificar as limitações e necessidades dos parques; esclarecer os papéis que os funcionários podem ter e deixar clara a contribuição do parque à sociedade.

Eagles e McCool (2004, p. 24) fizeram um pequeno esquema para representar as interrelações entre conservação e turismo:

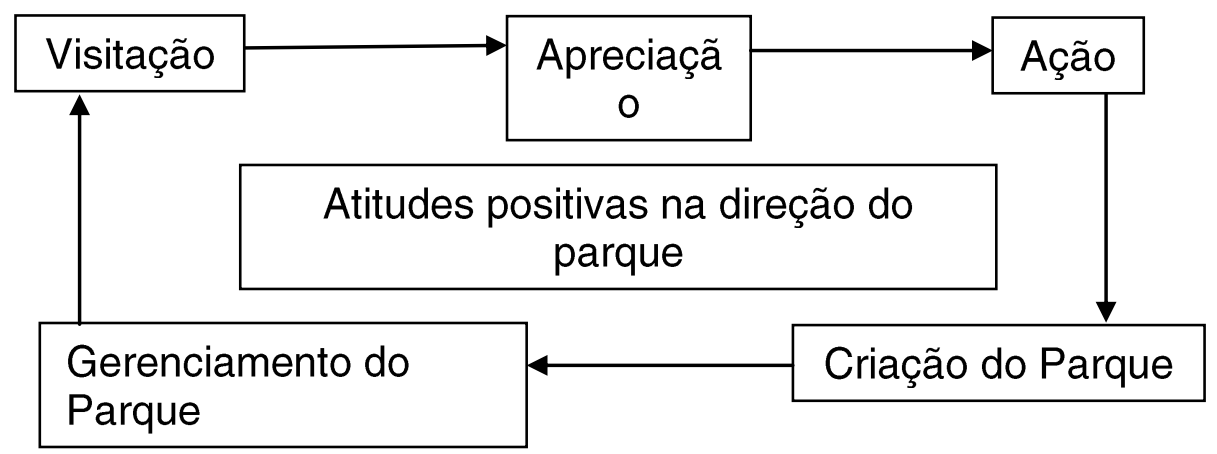

Fonte: adaptado de Eagles e McCool, 2004, p. 24 
A tabela 1 mostra a quantidade de visitantes recebida em alguns sistemas de parques no mundo:

Tabela 1: Índice de visitação em parques

\begin{tabular}{ccc}
\hline Sistemas de parque & Ano & Índice de visitação \\
\hline USA National Park System & 2000 & $\mathbf{4 2 9 . 8 5 3 . 1 2 3}$ \\
USA National Wildlife Refuge System & 1995 & $\mathbf{2 7 . 7 0 0 . 0 0 0}$ \\
Costa Rica National Park System & 1999 & $\mathbf{8 6 6 . 0 8 3}$ \\
Canada National Park System & 2000 & $\mathbf{1 5 . 6 9 0 . 0 7 3}$ \\
British Columbia Provincial Park System (Canada) & 2000 & $\mathbf{2 4 . 2 7 1 . 0 4 4}$ \\
California State Park System & 2000 & $\sim \mathbf{7 0 . 0 0 0 . 0 0 0}$ \\
New South Wales Park System (Australia) & 1997 & $\mathbf{1 9 . 9 8 8 . 2 8 1}$ \\
Kenya National Park System & 1996 & $\mathbf{1 . 3 8 1 3 . 7 0 0}$ \\
South Africa National Park System & $2000 / 2001$ & $\mathbf{2 . 4 4 0 . 9 0 2}$
\end{tabular}

TOTAL $\quad 604.623 .206$

Fonte: adaptado de Eagles e McCool, 2004, p. 278.

Muitos dos países citados na tabela permitem a instalação de campings e hospedarias dentro do Parque, o que não ocorre pela lei brasileira.

Devemos também assinalar que em muitos países em desenvolvimento, existe vontade política insuficiente para financiar o manejo de parques. Dourojeanni lembra que a falta de vontade política para estabelecer e, principalmente, para manejar parques está na visão bastante difundida entre a população leiga de que os parques são como terras inúteis. (Dourojeanni, 2002, p. 356).

O autor cita o Brasil como um caso de sucesso (2002, p. 357) onde "o governo brasileiro está atualmente desenvolvendo o PROECOTUR, um programa de ecoturismo que irá em breve abrir para visitação os mais famosos parques da Amazônia”. Porém, lamenta que apenas poucos parques 
nacionais estão abertos ao público e que somente recentemente (1997), o IBAMA, sob pressão do setor turístico, declarou sua "intenção de abrir a unidade para visitantes, em um esforço de promover o ecoturismo e a recreação". 


\section{A proteção dos parques}

Considerados área de proteção integral, os parques devem ter como prioridade a manutenção da biodiversidade e a conservação da natureza.

Segundo Barreto et. al. (2003, p. 135), "muitos dos problemas que hoje se colocam para a gestão e o manejo das unidades de conservação são heranças de conflitos e contradições não-equacionados quando da criação das mesmas."

Os autores lembram que, freqüentemente, o planejamento das unidades de conservação não está integrado às políticas de desenvolvimento e uso da terra em nível regional (2003, p. 143). E mais adiante lembram que "na maioria das vezes, as UCs sequer sejam efetivamente implantadas, sua simples criação - com a conseqüente redefinição do acesso aos recursos naturais da área - gera insegurança e instabilidade, fazendo com que, em alguns casos, o território de muitas delas seja dilapidado antes que sejam implantadas; ou então, com que as comunidades residentes no local permaneçam em situação de indefinição por longos anos, impossibilitadas de reorganizar satisfatoriamente suas vidas. Dessa forma, as UCs deixam de atender a um dos seus objetivos básicos: o de promover a melhoria da qualidade de vida da sociedade." (2003, p. 143)

Entre as principais metas e impactos do turismo em parques, Eagles e McCool (2004, p. 38-39), propõem diversos benefícios que podem resultar da criação de parques como o aumento nas oportunidades de emprego para populações locais, surgimento de oportunidades de educação aos membros da sociedade e aumento dos rendimentos e das riquezas. A sociedade cria parques para promover a conservação da herança natural e cultural. Como exemplo, os autores citam que no Canadá e nos Estados Unidos, onde o impacto econômico dos parques é calculado entre US\$236 e 370 bilhões de dólares por ano. 


\subsection{Os residentes humanos nos parques}

A presença de residentes nos parques aparece de forma recorrente como um 'problema' para as áreas protegidas. Segundo Terborgh e Peres (2002, p. 338-41), o único modelo de desenvolvimento que não causa impacto significativo sobre os recursos naturais é o ecoturismo. Os autores vislumbram que os administradores dos parques devem procurar um meio de incorporar os seus habitantes a uma economia de ecoturismo, resultando em uma situação positiva. O exemplo destacado pelo autor é o Parque Nacional Canaima, na Venezuela, que compreende três milhões de hectares e é um dos maiores do mundo. Segundo os autores (2002, p. 342), os indígenas da tribo Pemon vivem completamente integrados na economia de mercado e demonstram orgulho evidente nas suas habilidades para proporcionar um atendimento de alta qualidade aos turistas. O próprio autor adverte que o caso de Canaima é um caso especial e difícil de replicar, mas "não obstante ele ilustra como uma população indígena que vive dentro de um parque mudou seu estilo de vida e economia por vontade própria, de modo a adaptá-los a novas circunstâncias e oportunidades".

A dificuldade de copiar este modelo, segundo Terborgh e Peres (2002), reside no fato de que os habitantes locais são usualmente menosprezados pela população dominante e, em geral, os últimos a serem contratados.

Segundo Sano (2007, p. 96), "os parques são vistos pelas comunidades locais como o seu legítimo espaço de exploração econômica".

Segundo Terborgh e Peres (2002, p. 334), "um dos problemas mais intratáveis enfrentados pelos administradores dos parques é a presença de residentes humanos dentro das áreas protegidas. A questão é exacerbada quando os ocupantes são legal ou tacitamente reconhecidos pelo governo. Pessoas de todos os tipos, sejam indígenas ou não, representam uma ameaça séria à biodiversidade de qualquer parque, quando seus meios de vida são derivados dos recursos da área protegida”. Esta passagem deve ser criticada na medida em que aborda os residentes em parques como 'intratáveis' e 
'pessoas de todos os tipos' e, o autor não parece crer que existam comunidades que realmente dependam da área do parque para sua sobrevivência.

Os autores lembram que $70 \%$ dos parques nos países em desenvolvimento passam por este tipo de problema. E são categóricos ao afirmar: "por questão de princípio, parques livres de pessoas devem sempre ser a meta final. Este é o único objetivo que, a longo prazo, é consistente como os requerimentos da conservação da biodiversidade. Então, todas as políticas relevantes deveriam ser dirigidas para reduzir a presença humana dentro dos parques". (2002, p. 337)

No entanto, no caso das comunidades caiçaras e quilombolas do Núcleo Picinguaba do Parque Estadual da Serra do Mar, em Ubatuba, a gerente de unidades de conservação da Fundação Florestal, Adriana Mattos, em entrevista ao Estado de São Paulo (30/12/2007) diz: "por serem comunidades reconhecidamente tradicionais, decidiu-se que é o parque que deve se retirar". Assim, quatro populações deverão ser beneficiadas nas Vilas de Picinguaba e Cambury, e nos sertões da Fazenda e Ubatumirim - ao todo são 350 famílias de pescadores e quilombolas em 3.700 hectares. Adriana ainda lembra que comunidades não tradicionais não terão o mesmo privilégio e devem sair do parque. Dos cerca de $\mathrm{R} \$ 70$ milhões previstos para o Projeto Serra do Mar nos próximos quatro anos, cerca de $90 \%$ serão destinados para regularização fundiária.

Aqui cabe criticar diversos itens como a falta de uma definição quem é população local e até quando serão locais. A falta de critérios definidos para este tipo de situação acaba por gerar diversos conflitos e situações difíceis de reverter. 


\section{A questão econômica}

O turismo em parques necessita de uma infra-estrutura de facilidades que necessitam ser construídos e fazem parte do planejamento econômico dos parques. Takahashi $(2004$, p. 15) lembra que com o crescimento do número de visitantes, o custo de vida tende a se elevar. A elevação deste custo de vida pode tornar os rendimentos da população local inviáveis para suas necessidades.

Ortiz conta (2003, p. 85) que em 1949, o economista americano Harold Hotelling escreveu uma carta ao diretor do Serviço Nacional de Parques dos Estados Unidos. Ele sugeria que os custos incorridos pelos visitantes de um parque poderiam ser utilizados para o desenvolvimento de uma medida de valor de uso recreativo.

O método de custo de viagem, segundo Ortiz, utiliza questionários aplicados a uma amostra de visitantes do lugar de recreação para levantar dados como o lugar de origem do visitante, seus hábitos e gastos relacionados à viagem. As entrevistas devem respeitar os distintos períodos do ano (verão e inverno, diurno e noturno) evitando um possível viés sazonal na amostra (Romeiro, Maia e Reydon, 2004, p. 14).

Assim, de posse desses dados, pode-se calcular os custos de viagem e liga-los a uma freqüência de visitas, de modo que uma relação de demanda seja estabelecida. A partir desse dado - função de demanda por visitas ao lugar de recreação - estima-se o valor de uso desse lugar.

Segundo Ortiz (2003, p. 85-86), a lógica por trás desse método é "que, quando o recurso ambiental é utilizado para atividades recreativas, como parques, praias e lagos, gerando um fluxo de serviços mensuráveis para os indivíduos. Cada visita ao lugar de recreação envolve uma transação implícita, na qual o custo total de viajar a esse lugar é o preço que se paga para utilização dos serviços recreativos do parque, praia, lago etc." 
Ortiz nos lembra (2003, p. 88), porém, de vários problemas associados com a aplicação do método de custo de viagem. Segundo ele, a questão do destino múltiplo ou múltiplos objetivos numa mesma viagem, o tratamento do custo de oportunidade do tempo gasto para uma visita recreativa, a escolha de sítios substitutos ao local analisado, o tratamento do congestionamento como atributo de qualidade do sítio estudado e a forma funcional das curvas de demanda por visitas recreativas merecem atenção.

O autor, por outro lado, diz (2003, p. 88) que o método de custo de viagem é "uma ferramenta bastante útil para produzir estimativas do valor de uso recreativo associado a lugares de recreação, sendo metodologicamente consistente com a teoria econômica, de fácil aplicação e para produzir curvas de demanda por visitas recreativas ao sítio analisado, determinando, assim, a elasticidade-preço da demanda por visitas recreativas." De posse desse dado pode-se aprimorar a gestão da unidade de conservação simulando variações desses custos e prevendo os impactos no fluxo de visitas e na geração de receitas.

Segundo Calderoni (2004, p. 578) "existe uma grande dificuldade ao se estimar os custos de proteção ao meio ambiente, ou seja, da carga econômico-financeira dos programas de preservação ambiental e de luta contra a poluição. Dessa forma, na falta do custo relevante, costuma-se utilizar despesas realizadas na proteção ambiental, tanto do poder público quanto dos indivíduos e das empresas."

Calderoni ainda lembra que "os métodos utilizados para estimar o custo de proteção ambiental variam de acordo com a esfera em que são realizados. No caso do setor público, trata-se de listar todas as despesas ligadas à qualidade ambiental, em todas as esferas do poder - federal estadual e municipal. Apesar de aparentemente simples, até o momento não existe no Brasil nenhuma avaliação desse tipo". (2004, p. 578) 
Segundo Spergel (2002, p. 334-413), "quase universalmente, os parques tropicais de países em desenvolvimento são severamente subfinanciados, tendo como resultado previsível considerável redução de sua biodiversidade. Os orçamentos médios para as áreas protegidas em países em desenvolvimento estão em torno de $30 \%$ da quantidade mínima requerida para conservar aquelas áreas. Como as verbas podem ser aumentadas para as áreas protegidas em países em desenvolvimento?". Seria por intermédio, segundo o autor, de:

a) alocações anuais do orçamento do governo

b) taxas pagas por usuários e taxas ambientais que sejam destinadas aos parques e à conservação da natureza

c) verbas e doações de indivíduos, corporações, fundações, ONGs e agências internacionais de doação.

O autor lembra que "o turismo baseado em natureza e na vida selvagem pode se tornar uma peça importante no crescimento econômico e na geração de empregos em países em desenvolvimento. Em adição ao turismo, as áreas protegidas podem também prover serviços ecológicos valiosos, sem os quais o governo deveria investir dinheiro." (Spergel, 2002, p. 334-413)

Por fim, Spergel comenta que "algumas das maneiras de aumentar as rendas das taxas e dos impostos oriundos das áreas protegidas residem na coleta de taxas maiores dos estrangeiros do que as cobradas para os visitantes nacionais; em entradas mais altas em épocas de pico; e taxas separadas para atrações recentemente desenvolvidas, tais como a iluminação de cavernas, caminhadas nas copas da floresta ou trilhas guiadas". (2002, p. 334-413)

Segundo Ortiz (2003, p. 83), "o principal objetivo da valoração econômica ambiental é estimar os custos sociais de se usar recursos ambientais escassos ou, ainda, incorporar os benefícios sociais advindos do 
uso desses recursos. A valoração econômica ambiental é fundamental para a gestão de recursos ambientais, bem como para a tomada de decisões que envolvam projetos com grande impacto ambiental."

O autor lembra (2003, p. 97-98) que "no Brasil, ainda são poucas as experiências com a utilização de métodos de valoração econômica ambiental".

Um estudo sobre a economia de um parque também foi feito por Ortiz, Motta e Ferraz (2001) para o Parque Nacional do Iguaçu, utilizando-se o método de custo de viagem para estimar seu valor de uso recreativo. A dificuldade de determinar esse valor pode ser percebida no resultado: uma variação entre US\$ 12 milhões e US\$ 34 milhões.

Segundo Lindberg e Huber Jr. (2001, p. 174-175), "os gestores devem decidir que taxas especificas deveriam ser cobradas para bens e serviços e como cobrá-las". Os autores apresentam cinco categorias de taxas mais comuns: a taxa de entrada (ingresso), a taxa de admissão, a taxa de utilização, a taxa de licença ou autorização e as taxas geradas por vendas e concessões.

Por fim, vale lembra que VENTURI (1993, p. 108-109) comprovou que "a falta de recursos humanos implica mais conclusivamente na falta de recursos financeiros do que o contrário".

\subsection{Quanto custa um parque?}

O estabelecimento de um parque, segundo Valério (apud Marcondes, 1980 , p. 18) implica em gastos significativos em estudos preliminares e especialmente na desapropriação de terras. Segundo o autor, uma vez que um parque entra em funcionamento e os terrenos são de propriedade do Estado, é necessário financiar a construção de vias de acesso, trilhas, edifícios de administração e de serviços, vivendas e todos outros detalhes necessários para fazê-lo acessível aos visitantes. 
O SNUC, no artigo 5, parágrafo $\mathrm{VI}$, tem como diretriz "assegurar, nos casos possíveis, a sustentabilidade econômica das unidades de conservação".

Segundo Marcondes (1980, p. 79), para a determinação dos custos do parque Nacional de Cahuita na Costa Rica, foram considerados dois tipos de custos: "os custos de implantação das instalações atualmente disponíveis e os custos de operação do parque". O autor afirma que "um aspecto importante a se destacar é que a totalidade de custos que incorre no Parque Nacional de Cahuita são custos fixos, ou seja, independente do número de visitantes e do uso do mesmo".

Em seu trabalho, os custos de implantação do Parque Nacional de Cahuita (com uma área de 1.000 ha de terra e 600 ha no oceano) foram de US\$ 2.761.538,64, incluindo a mão-de-obra, os materiais e os terrenos. (1980, p.81) Os custos de manutenção, por ano, segundo o autor, eram de US\$ 72.276, 35 para mão-de-obra (salários) e de US\$ 15.020,85 de manutenção. Vale lembrar que os custos são referentes ao ano de 1979, ou seja, quase trinta anos atrás e que, atualmente, muitos gastos considerados não devem ser incluídos e outros podem ser incluídos.

Para uma idéia atual dos custos de manutenção de um parque, selecionamos o Parque Nacional de Yellowstone (EUA), o Parque Estadual da Serra do Mar (Brasil), o Parque Estadual de Porto Ferreira (Brasil) e o Parque Nacional do Iguaçu (Brasil). Apesar de não servirem para efeito comparativo, pois cada parque tem suas peculiaridades (tamanho, número de visitantes, nível de renda etc.), ajuda a ter uma relativa idéia de quais os custos de manutenção de um parque e das necessidades previstas em seus planos de manejo.

O Parque Nacional de Yellowstone, localizado nos Estados Unidos, foi o primeiro parque a ser constituído no mundo, no ano de 1872, com uma área de 2,2 milhões de acres (890 mil ha). Segundo o "Yellowstone National Park 
Business Plan", de julho de 2003, em 1895, quando se iniciou a visitação por trilhas, 5.438 pessoas visitaram o parque. Em 2002, mais de um século depois, esse número saltou para 2.978 .360 visitantes. O relatório lembra que, em alguns anos, como 1988, o índice de visitação caiu em 15\% devido a queimadas, mas já em 1989, o índice havia retornado ao normal.

O relatório, de extrema qualidade técnica e visual, indica que $93 \%$ dos visitantes são americanos, $78 \%$ visitaram o parque com suas famílias e $95 \%$ viajaram com seu próprio veículo. Os autores lembram que $95 \%$ das visitações ocorrem no verão, mas o índice cresceu rapidamente no inverno, no período de 1975 a 2000 , de 70.000 para 140.000 visitantes, exigindo pessoal e fundos adicionais. Atualmente, o parque conta com 387 funcionários permanentes.

Gráfico 1: Despesas correntes nas operações do parque

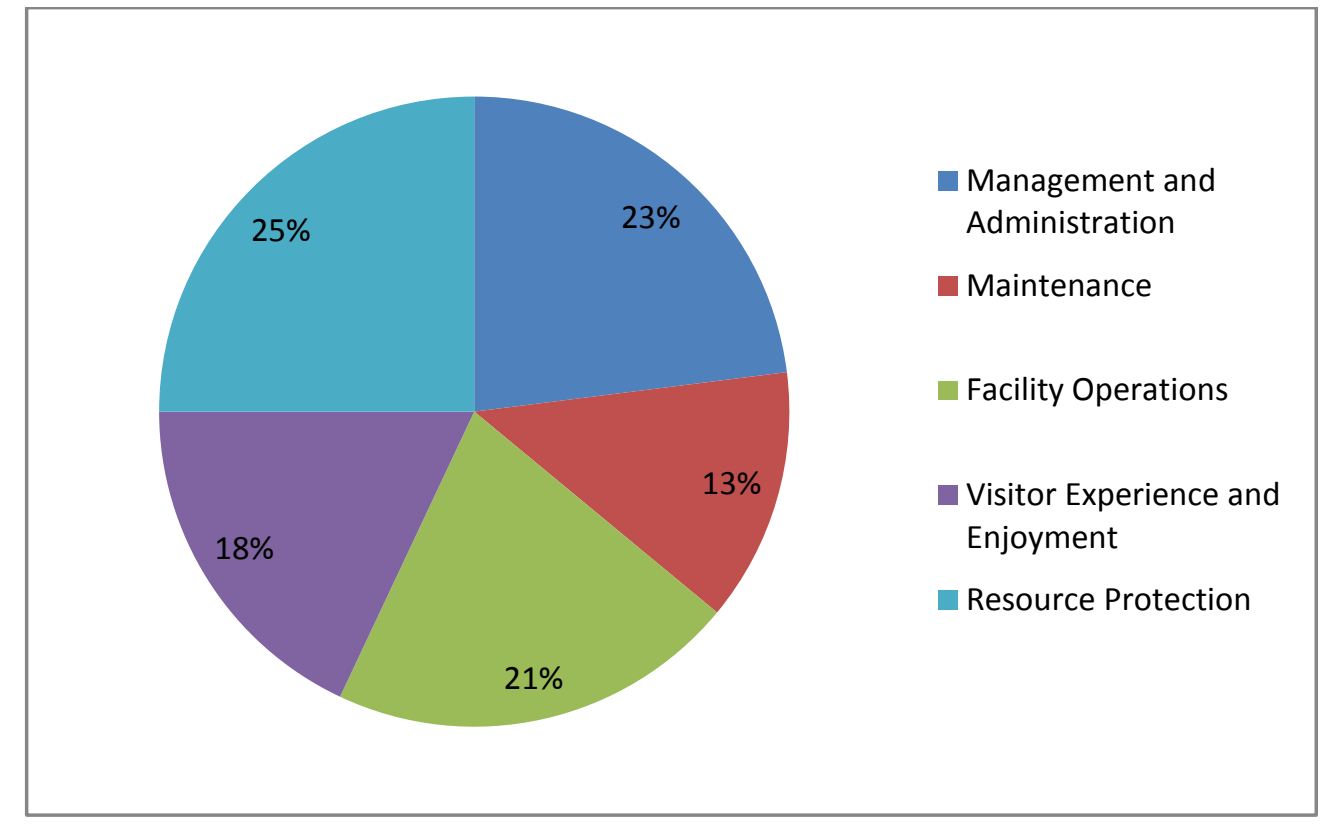

Fonte: National Park Service (NPS), 2003.

O Yellowstone National Park (YNP) tem uma infra-estrutura gigantesca com: 1541 prédios (incluindo 831 mantidos sob concessões); 454 alojamentos (incluído 68 trailers); nove centros de visitantes, museus e estações de contato; sete acampamentos gerenciados pelo National Park Service; sete anfiteatros, 52 áreas de piquenique. Ele gera três mil toneladas de lixo por ano (13\% são reciclados). Como se pode perceber é um parque de grandes proporções e de 
difícil comparação com outros parques no Brasil ou no mundo. Porém, podemos analisar os extremos custos que podem ter um parque no mundo.

Dividido em cinco grandes áreas, o Yellowstone National Park tem um custo anual total de US\$ 64.422.471 (ver tabela 2).

Tabela 2: Divisão dos fundos requeridos para o Yellowstone National Park

\begin{tabular}{|c|c|}
\hline Áreas Funcionais e Programas & Fundos Requeridos (em US\$) \\
\hline Proteção dos Recursos & $13.549 .365,00$ \\
\hline Experiência do Visitante e Apreciação & $16.863 .889,00$ \\
\hline Operações das Instalações & $12.356 .109,00$ \\
\hline Manutenção & $7.720 .998,00$ \\
\hline Gerência e Administração & $13.932 .110,00$ \\
\hline TOTAL & $\mathbf{6 4 . 4 2 2 . 4 7 1 , 0 0}$ \\
\hline
\end{tabular}

Tabela produzida pelo autor a partir dos dados obtidos em NPS, 2003, p.27.

Produzido em 2005/2006, pelo Instituto Florestal do Estado de São Paulo e o Instituto EkosBrasil, o Plano de Manejo do Parque Estadual da Serra do Mar (criado em 1977) traz um interessante relatório sobre os custos do parque, que abrange 23 municípios do Estado do litoral e Vale do Paraíba, sendo a maior área de proteção integral da Mata Atlântica, com 315 mil ha. É um orçamento preliminar de custeio e investimentos de reposição do parque, para o período de 2006 a 2010. Foram considerados quatro grupos: quadro de pessoal, mobilização, bens imóveis e operação (tabela 3).

- Quadro de pessoal: foi considerado o total anual de 13 salários, sem encargos;

- Mobilização: investimentos em veículos, motos, custeio de veículos, vôo de helicóptero;

- Bens Imóveis: custeio de conservação de imóveis e despesa com a vigilância do patrimônio.

- Operação: investimento com reposição de equipamentos, despesa com custeio de escritório, despesa com comunicação telefônica, despesas com radiocomunicação, despesa com a 
manutenção do SIGMA, despesa com custeio de alimentação, despesa com outros materiais e despesa com serviços de terceiros.

Tabela 3: Custo Anual do Parque Estadual da Serra do Mar

\begin{tabular}{|c|c|}
\hline Item & Custo Total Anual (em R\$) \\
\hline Quadro de Pessoal & $2.711 .040,00$ \\
\hline Mobilização & $1.453 .000,00$ \\
\hline Bens Imóveis & $2.005 .440,00$ \\
\hline Operação & $1.089 .896,00$ \\
\hline TOTAL & $\mathbf{7 . 2 5 9 . 3 7 6 , 0 0 ( 2 )}$ \\
\hline
\end{tabular}

(1) Tabela produzida pelo autor a partir dos dados obtidos em IF, 2006, p. 415-418.

(2) Desse total, $6,68 \%$ é destinado a Administração Central do Parque e $93,32 \%$ para os Núcleos.

Se colocarmos esse valor em dólares, apenas para efeito de comparação, chegaremos à quantia de US $\$ 4.245 .249,12^{3}$, valor bem menor do que o gasto em Yellowstone.

O Parque Estadual de Porto Ferreira tem uma área de 611,55 ha e foi criado em março de 1987. O Plano de Manejo do Parque Estadual de Porto Ferreira, também elaborado pelo Instituto Florestal, apresentado em setembro de 2003, apresenta nove grandes programas para o seu manejo, que deve ser realizado no período de cinco anos. O custo total é de $R \$ 1.171 .600,00$. Seguem, na tabela 4 , os custos de cada programa.

3 US $\$ 1,0$ equivale a $R \$ 1,71$ no dia 16/03/2008. 
Tabela 4: Custo dos Programas para o Manejo do Parque Estadual de Porto Ferreira

\begin{tabular}{|c|c|}
\hline $\begin{array}{c}\text { Programa } \\
\text { ambiente }\end{array}$ & \begin{tabular}{c} 
Custo para cinco anos (em R\$) \\
\hline $\begin{array}{c}\text { Programa de protec̃ão e manejo do meio } \\
\text { monitoramento }\end{array}$
\end{tabular} \\
\hline Programa de uso público & $31.800,00$ \\
\hline Programa de Operações Internas & $219.000,00$ \\
\hline Programa de Controle Ambiental & $567.400,00$ \\
\hline Programa de Educação Ambiental & $45.500,00$ \\
\hline Programa de Alternativas de & $34.500,00$ \\
\hline Desenvolvimento & $42.000,00$ \\
\hline Programa de Integração Externa & $17.000,00$ \\
\hline Programa de Operações Externas & $11.000,00$ \\
\hline TOTAL & $\mathbf{1 . 1 7 1 . 6 0 0 , 0 0}$ \\
\hline
\end{tabular}

(1) Tabela produzida pelo autor a partir dos dados obtidos em IF, 2003.

O valor, portanto, dos custos do Parque Estadual de Porto Ferreira, são bem menores do que os outros dois apresentados.

O Parque Nacional do Iguaçu, localizado estado do Paraná, tem uma superfície de 185.262,5 hectares, foi criado em janeiro de 1939 e é um dos parques mais visitados do Brasil. Em 1971, o Parque recebeu 270.754 visitantes e, em 1979 recebeu 712.317 (IBDF, 1981, p. 47). Atualmente, o Parque recebe mais de 900 mil visitantes por ano (2006).

O Plano de Manejo, feito em 1981, apresenta uma planilha de custo para os cinco anos seguintes, mas muito desatualizada. No entanto, em 1999, o IBAMA produziu uma atualização do Plano de Manejo com uma nova planilha de custos conforme segue. 
Tabela 5: Custo dos Programas para o Manejo do Parque Nacional do Iguaçu

\begin{tabular}{|c|c|}
\hline Programa & Custo para cinco anos (em R\$) \\
\hline Programa de Conhecimento & $2.711 .600,00$ \\
\hline Programa de Uso Público & $8.594 .000,00$ \\
\hline $\begin{array}{c}\text { Programa de Integração com a Área de } \\
\text { Influência }\end{array}$ & $1.189 .000,00$ \\
\hline $\begin{array}{c}\text { Programa de Manejo do Meio } \\
\text { Ambiente }\end{array}$ & $1.928 .300,00$ \\
\hline Programa de Operacionalização & $7.515 .200,00$ \\
\hline TOTAL & $\mathbf{2 1 . 9 3 8 . 1 0 0 , 0 0}$ \\
\hline
\end{tabular}

(1) Tabela produzida pelo autor a partir dos dados obtidos em IBAMA, 1999.

Notadamente, podemos observar que o custo do Parque Nacional do Iguaçu é o maior dos parques analisados. 


\section{O Planejamento para o turismo em parques}

A gestão dos parques é um dos principais pontos relativos à conservação e ao turismo nestas áreas. Segundo Sano (2007, p. 95), a forma como é feita a gestão dos parques causa resultados díspares no ecoturismo e na manutenção dos parques. A autora lembra que o planejamento é importante para a preservação do meio ambiente natural e seu uso racional no sentindo econômico.

Segundo Santos (2004, p. 16), sempre que um grupo de pessoas se propõe a viver em estado gregário, sob objetivos e normas comuns, a organização do espaço é uma premissa. A autora lembra que os primeiro estudos de avaliação de impactos refletiam "sistemas de planejamento" de caráter ambiental e os métodos adotados eram uma soma das avaliações de custo/benefício, técnicas de questionamento e métodos baseados em listagens, desenvolvidos entre os anos 1930 e 1970. (2004, p18)

Laurie (1983, p. 165) define o planejamento da paisagem como "O processo positivo com a intenção de acomodar certos usos de solo as terras melhores dotadas para os mesmos, e como um processo negativo cuja missão é evitar o deterioramento ou o consumo ecológico de alguns recursos naturais, como o solo agrícola de boa qualidade ou a água pura”.

Rozely SANTOS define planejamento como "um processo contínuo que envolve a coleta, organização e análise sistematizadas das informações, por meio de procedimento e métodos, para chegar a decisões ou a escolhas acerca das melhores alternativas para o aproveitamento dos recursos disponíveis" e sua finalidade "é atingir metas específicas no futuro levando à melhoria de uma determinada situação e ao desenvolvimento das sociedades". (Santos, 2004, p. 23)

O planejamento ambiental surge, segundo Santos (2004, p. 27), "nas três ultimas décadas, em razão do aumento dramático da competição por terras, água, recursos energéticos e biológicos, que gerou a necessidade de 
organizar o uso da terra, de compatibilizar esse uso com a proteção de ambientes ameaçados e de melhorar a qualidade de vida das populações. $O$ planejamento ambiental vem com uma solução a conflitos que possam ocorrer entre as metas da conservação ambiental e do planejamento tecnológico". A autora lembra que o planejamento ambiental visa a sustentabilidade e considera critérios a longo prazo mas estabelece medidas a médio e longo prazo e tem como fundamentos a interação e integração dos sistemas que compõem o ambiente. Por fim, a autora lembra que "os planejamentos ambientais, pelo menos no Brasil, não representam de forma eficiente a realidade, nem atingem o ideário a que se propõem. O momento é de reflexão sobre a eficiência do discurso teórico, bem como a sobre a construção da teoria e do método". (2004, p. 28-29)

O planejamento para o turismo em parques deve ser parte integrante do Plano de Manejo, visto que a visitação é um dos objetivos da criação de tais áreas de proteção. O planejamento é "necessário para assegurar que o futuro desejado se torne realidade" (Eagles e McCool, 2004, p. 77). O autor demonstra tal pensamento no esquema a seguir:

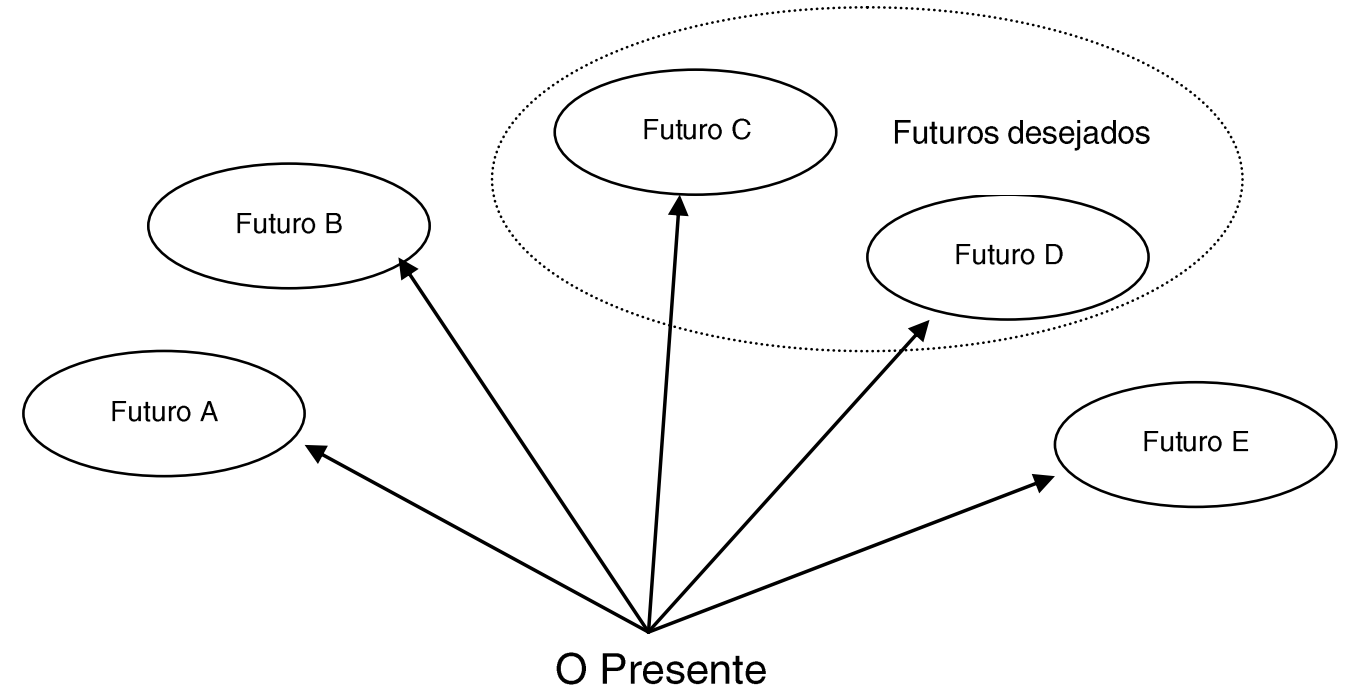

Adaptado de Eagles e McCool (2004, p.

Eagles e McCool lembram (2004, p.78) que o planejamento é um processo de análise e avaliação que leva a um plano de manejo que é um documento formal indicando os objetivos, os meios para alcançá-los e o 
monitoramento das estratégias. Planos de manejo são implementados com compromissos anuais de fundos, pessoas e políticas. Implementação é o monitoramento para assegurar que os objetivos estabelecidos no processo de planejamento sejam conquistados. Tal monitoramento não apenas assegura os avanços, mas é também uma forma de imposição para garantir não apenas que os visitantes sigam as regras, mas também para que as organizações dos parques cumpram seus compromissos. Assim, segundo os autores, tem-se uma relação entre planejamento, manejo, implementação, monitoramento e imposição, todas as palavras-chave na proteção da herança cultural e natural que cada organização tem a responsabilidade de administrar.

Santos (2004, p. 19-20), lembra que "os objetivos, a estrutura e os procedimentos em um planejamento serão definidos a partir de um ideário, norteador de todo o seu processo, que levará os conceitos e premissas de desenvolvimento, para um certo espaço, num determinado tempo. Se o ideário se concretizar, então passará a ser considerado um modelo, uma referência ou o paradigma a ser examinado pelo planejador".

Segundo Eagles e McCool (2004, p. 84-88), os planejadores de parques têm dois grandes desafios quando iniciam o planejamento de uma área específica: primeiro, eles devem definir um processo de planejamento o qual seja cientificamente e tecnicamente "sonoro", inclusive pelas partes afetadas por ou envolvidas no parque, conduzido de maneira oportuna e eficiente; o segundo, os resultados do processo de planejamento devem ser colocados em uma fundação firme de entendimento não apenas dos valores dos parques, mas também de seus papéis em uma sociedade. Os autores apresentam diversos princípios (2004, p.85-88) que devem guiar o processo de planejamento para alcançar estes dois objetivos.

Princípio 1: Deve haver um critério explícito para a avaliação de alternativas 
Os planos de manejo 4 para parques e áreas protegidas devem ser projetados para achar as rotas para os futuros desejados. Para cada rota, existem diversas alternativas. Os critérios usados para selecionar o "melhor" caminho são fundamentais para o empenho no projeto. Quais critérios são escolhidos vão determinar quais alternativas serão selecionadas como as preferidas. Critérios podem incluir equidade, eficiência e interesses de efetivações. Eles podem refletir desejos para melhorias na qualidade das recreações ou podem lidar com a quantidade de impacto social ou ambiental. Uma vez escolhido o critério, as alternativas são avaliadas e a tomada de decisão é determinada.

Princípio 2: Planejamento de parques requerem uma variedade de formas de conhecimento

Existem diversas formas de conhecimento disponíveis para os planejadores e tomadores de decisões. Nenhuma forma de conhecimento é melhor que a outra, todas são válidas. Algumas fontes que serão usadas no planejamento são exatas e de confiança, outras podem não ser.

Princípio 3: Planejamento de parques em situações desordenadas ${ }^{5}$ requerem participação pública

A participação do público é o carimbo do planejamento contemporâneo de áreas protegidas. A implementação dos planos dependem muito da apreciação e suporte público; nada é desenvolvido quando as agências escrevem planos fora do alcance da sociedade. Planejadores, quando desenvolvem o processo de planejamento, precisam desenvolver um plano de envolvimento do público o qual específica os objetivos do envolvimento público, como o público será envolvido, quando, e como as sugestões e comentários do público serão tratados.

\footnotetext{
4 Traduzimos "park plan" como "plano de manejo"

${ }^{5} \mathrm{O}$ autor considera situação desordenada (traduzido de messy situation) como parques que ainda não têm suas áreas totalmente regularizadas ou com populações dentro do parque
} 
Princ ípio 4: Incertezas e riscos devem ser reconhecidos no plano de manejo

Nosso conhecimento sobre as conseqüências de ações de manejo é limitado; freqüentemente tais ações levam a conseqüências não esperadas efeitos que não foram ou não puderam ser previstos. Incerteza é a condição quando probabilidades não podem ser determinadas para os efeitos. $O$ risco ocorre quando nós conhecemos a distribuição dos efeitos e podemos determinar a probabilidade de suas ocorrências. O processo de planejamento deve detalhar como incertezas e riscos serão tratados. ${ }^{6}$

Princípio 5: O plano deve localizar a escala temporal e espacial nãocorrespondentes

A não-correspondência de escala ocorre quando um processo ecológico ou social opera em numa escala e outro processo ocorre outra. Processos ecológicos, como sucessão vegetal podem operar em escala de décadas, enquanto apropriações financeiras para manejar a vegetação ocorrem em nível bianual. Os planos devem ser flexíveis, adaptáveis e responsáveis para mudanças ambientais institucionais. O plano deve conter mecanismos para lidar com mudanças potenciais.

Princípio 6: Planos de manejo incluem relatórios de requerimentos de pessoal e financeiros para implementação.

Planos de manejo sem estratégias de implementação estão destinados a falharem simplesmente porque eles não articularam a responsabilidade, os custos e a negociações requeridas para os objetivos identificados.

Santos (2004, p. 25) lembra que "planejamento é uma atividade para ser implementada e não apenas uma produção de documentos. O processo não se esgota na implementação, tendo continuidade ao longo do tempo".

\footnotetext{
${ }^{6}$ Segundo Amaral e Silva (2004, p. 799-801), "no processo brasileiro de gerenciamento ambiental, é claramente constatável a deficiência dos usos de comunicação de riscos e problemas que afetam o meio ambiente".
} 
O planejamento de parques está também relacionado à arquitetura da paisagem. Laurie (1983, p. 21) lembra que nos anos da depressão de 1930, os arquitetos paisagistas trabalhavam em trabalhos de grande envergadura e numerosos programas de atuação pública, especialmente nos trabalhos para a U.S. National Parks Service. O autor lembra que são três as atividades dos arquitetos paisagistas: a planificação e estimativas da paisagem, a planificação dos terrenos e, por fim o desenho detalhado da paisagem, que se baseia na seleção de componentes, materiais e plantas.

Manuela Raposo MAGALHÃES (2001, p. 62) aponta que o objeto da arquitetura paisagista é vasto e, portanto sua intervenção processa-se em diferentes escalas: desde 1:10 até 1:4.000.000.

Domingo GÓMEZ OREA (1978, p. 24-25) assinala que a o planejamento depende 'especialmente das características de âmbito geográfico ou região a ordenar'. Segundo o autor, existem duas regiões bem contrastadas e que exigem enfoques diferentes: as áreas deprimidas, geralmente de caráter rural e a as áreas de rápido crescimento.

\subsection{O plano de manejo}

Segundo Boo (2001, p. 37), há um súbito aumento no número de visitantes que procuram os parques e os administradores de áreas protegidas precisam avaliar que nível de turismo é o melhor para cada área, arquitetando uma estratégia que atinja o nível desejado. Esta estratégia, segunda a autora, tem três fases: avaliação da situação e potencial do turismo; determinação de uma situação de turismo desejável e a identificação dos passos para concretizá-la e, por fim, escrever um documento sobre a estratégia ecoturística. A autora cita uma série de perguntas que devem ser respondidas para atender estas três fases.

Segundo Lucas (1992, p. 96-97), todo plano precisa incluir: 
1. O contexto nacional e regional da área;

2. Uma descrição e inventário da área suficiente para estabelecer o contexto do gerenciamento;

3. Os objetivos;

4. As considerações do gerenciamento;

5. Estratégias para alcançar conservação, recreação e desenvolvimento rural;

6. As maneiras de implementação.

O autor lembra que o plano de manejo de uma área protegida não é o fim por si só, mas, como o conceito de área protegida, significa o alcance do gerenciamento mais efetivo da região e seus recursos biológicos, culturais, sociais e econômicos.

Segundo o SNUC (op. Cit.), manejo é "todo e qualquer procedimento que vise assegurar a conservação da diversidade biológica e dos ecossistemas".

\subsection{Serviços de turismo e infra-estrutura em parques}

Parques e áreas protegidas requerem infra-estruturas, serviços de acomodação para seus visitantes, equipe de trabalho e outros. $O$ turismo em parque requer infra-estrutura para informação, transporte, acomodação, alimentação, segurança e recreação. Para realizar essas necessidades comuns, as instalações podem incluir centro de visitantes, estradas, campings, lojas de conveniência, infra-estrutura de água e esgoto e trilhas. O projeto e a operação dos serviços de turismo em parques é um campo especializado. Segundo Eagles e McCool (2004, p. 172), a infra-estrutura em parques e áreas protegidas devem ser projetadas para preencher funções básicas como oportunidades de aumentar a recreação, aumentar a capacidade para o turismo, apoio à saúde do visitante, diminuição dos custos de manutenção, ter uma fiscalização responsável, proteger e manter a integridade ecológica, 
apoiar a integridade cultural, manter a saúde do ar, água e solo e providenciar as necessidades de pessoal.

O projeto de infra-estrutura para assegurar a melhor prática no turismo voltado à natureza, segundo Eagles e McCool (2004, p.183), pode ser desenvolvido levando em consideração cinco critérios:

I. O Projeto Sustentável deve ser evidente. Turismo deve ser projetado com e para o ambiente.

II. Interpretação deve levar o consumidor a entender e apreciar o processo ambiental.

III. Envolvimento da comunidade local deve ser extremamente evidente. Isto pode ocorrer com o envolvimento direto da população local ${ }^{7}$ ou através da inclusão de elementos culturais. Isto pode ocorrer com a arquitetura do local e a entrega de serviços de hospitalidade.

IV. Retorno financeiro para o ambiente deve ser evidente. O negócio do turismo deve retornar parte dos seus ganhos para a conservação ambiental.

V. Alta qualidade em alimentação, bebida e outros serviços de hospitalidade devem estar presentes.

Por fim, Eagles e McCool lembra que "a infra-estrutura do parque é um componente crítico da experiência do visitante. Deve ser projetado e gerenciado cuidadosamente de maneira a preencher tanto as necessidades dos usuários do parque e a proteção do ambiente e os valores culturais do parque". (2004, p. 184)

Os parques nacionais e estaduais, por serem áreas públicas, devem atender a todos os públicos, tanto das classes mais abastadas como das menos favorecidas. Portanto, é necessário que os parques tenham uma comunicação adequada para essas camadas sociais, atendendo assim todos os visitantes. Um sistema de identidade visual capaz de ser 'lida' por todos

\footnotetext{
${ }^{7} \mathrm{O}$ autor não detalha em quais áreas deve ocorrer este envolvimento nem define 'população
} local'. 
deve fazer parte do planejamento dos parques. A necessidade de localização e de informações sobre o parque é essencial para o bom aproveitamento turístico bem como para a segurança de seus usuários.

Segundo Vasconcellos (2006, p. 71), uma programação compreensiva de transmissão e instruções deve cumprir desígnios como: placas reguladoras (divulgam normas, regras e as precauções), placas informativas (informam as distâncias e os nomes dos lugares), placas indicativas (indicam direções) e as placas interpretativas (explicam as características naturais ou culturais e seus significados). A manutenção das placas também deve ser pensada, utilizando-se materiais fáceis de limpar e letreiros que possam ser substituídos.

\subsection{Impactos do turismo em parques e seu entorno}

Segundo Eagles e McCool (2004, p. 151-152), de maneira a atingir os objetivos totalmente, os visitantes dos parques requerem infra-estrutura, serviços e programas. A infra-estrutura de transporte é construída, serviços de segurança são desenvolvidos, programas de informação são providenciados, comida é comprada, fotos são tiradas, acomodações são usadas. Claramente, a visitação em parques tem impactos sociais, culturais, econômicos e ambientais. Alguns impactos são inevitáveis, no entanto, podem ser planejados para serem gerenciados. Cabe lembrar que não somente visitantes, mas pesquisadores e outros colaboradores também necessitam de uma infraestrutura de boa qualidade para seus trabalhos.

Eagles e McCool (2004, p. 151) lembram que o monitoramento envolve um programa de mensuração do impacto. Normalmente, os administradores de parques desenvolvem um programa para medir os impactos de atividades específicas.

Segundo Terborgh e Davenport (2002, p. 430-432), existem diversos alvos que devem ser monitorados como questões socioeconômicas (pressão 
demográfica no entorno dos limites do parque, atitudes da população local, economia local, retirada de recursos em grande escala e sistema predominante de propriedade de terras); ameaças resultantes de atividade legais (presença de residentes legais dentro dos limites, 'uso sustentável' permitido dos recursos da área protegida, turismo, atividades recreativas, manejo de lixo); ameaças resultantes de atividades ilegais (caça clandestina, exploração madeireira, mineração, pastoreio por gado doméstico, invasão por posseiros, comercialização de produtos naturais); ameaças 'invisíveis' (documentos de criação ineficientes, problemas de titulação de terras, falta de posse dos recursos do subsolo, falta de vontade política para reforçar os regulamentos, falta de cooperação interinstitucional (polícia, tribunais, existência de propriedades privadas dentro do parque, hierarquia de ministérios, existência de legislação contrária ao parque); administração e manejo (orçamentos, equipe, aparelhamento do pessoal, capacidade de fiscalização, manejo do ecoturismo, indicações de corrupção, definição e demarcação de limites); recursos naturais (indicadores biológicos, espéciesbandeira, endêmicas, espécies de valor comercial excepcional, qualidade da água); ameaças além dos limites do parque (mudança climática global, poluição de ar e água, incêndios, invasões por espécies exóticas).

Segundo a IUCN (1986, p. 87), são impactos negativos do ecoturismo em áreas protegidas:

- A superlotação, que gera estresse ambiental;

- O 'superdesenvolvimento', com infra-estrutura em excesso;

- A recreação que pode gerar distúrbios na vida selvagem;

- A poluição - sonora e vandalismo;

- A alimentação de animais;

- A alta velocidade dos carros e a presença de carros off-road pode causar mortalidade dos animais e danos ao solo e a vegetação;

- A venda de souvenires, que remove as atrações naturais;

- A presença de linhas de energia, que pode destruir a vegetação;

- A introdução de plantas exóticas e animais. 
E podemos citar também a retirada de plantas, animais e amostras de rochas.

Segundo Davenport, et. al. (2002, p. 321), a utilização da metodologia LAC (limites aceitáveis de câmbio) "tem sido proposta como uma alternativa para os métodos de capacidade de carga no monitoramente e na mitigação de danos aos recursos naturais dos parques. Em vez de perguntar "qual o uso máximo?", a metodologia LAC pergunta "que condições naturais são desejáveis aqui?"”. 


\section{Algumas experiências de turismo em parques}

Utilizado como exemplos o Vietnã e o Camboja, Cresswell e Maclaren (2000, p. 295-296) sumarizaram uma série de oportunidades e intervenções para o desenvolvimento do turismo em parques de países emergentes. Dentre os potenciais, eles sinalizaram: a diversidade cultural e ecológica, promoção da conservação de fauna e flora rara e nativa e o aumento do intercâmbio e a promoção do desenvolvimento sócio-econômico incluindo sociedades humanas sustentáveis. Dentre as fraquezas, encontram-se: a intranqüilidade civil e política, carência de investimentos e turistas forçados a esses riscos, carência de infra-estrutura e outros assuntos genéricos dos países em desenvolvimento.

Cresswell e Maclaren (2000, p. 296) citam como oportunidades para os países emergentes a possibilidade de aprender com os erros de outros lugares e incorporar estratégias de gerenciamento proativas preventivas ao invés de medidas mitigadoras reativas e 0 suporte global para o desenvolvimento sustentável pode beneficiar o turismo voltado à natureza. No entanto, algumas ameaças como a pressão do senso comum exercida pela globalização, exploração cultural e o comércio de espécies em extinção e o crescimento do número de visitantes gerando conseqüências adversas para o ambiente, como distúrbios de espécies sensíveis e novas construções resultantes da infraestrutura para o turismo (centro de visitantes, trilhas, estacionamentos).

Alguns parques apresentam também exageros na infra-estrutura. $O$ Kruger National Park, na África do Sul é um exemplo. Segundo Takahashi (2004, p. 15) o parque apresenta 4.000 leitos para turistas, loja de souvenires, restaurante, lanchonete, mercado de frutas e até posto de gasolina! A autora lembra que existem verdadeiras 'vilas', onde as pessoas passam dias e "às vezes, esquecem-se que estão dentro de um parque".

O Yellowstone National Park é considerado por Takahashi como um outro exemplo de um parque que se transformou num "gueto urbano de turistas, repleto de crime, lixo e vandalismo". (TAKAHASHI, 2004, p. 15) 


\section{Caso estudado}

\subsection{O turismo em Campos do Jordão}

O município de Campos do Jordão foi criado, com autonomia políticoadministrativa, em 16 de junho de 1934, quando se desligou de São Bento do Sapucaí. Em 30 de novembro de 1944, foi criada a sua comarca. O nome da cidade remonta o Brigadeiro Manoel Rodrigues Jordão, que comprou as terras pertencentes à família Vieira de Carvalho, quando se aproximava o natal. Inicialmente, elas eram chamadas de 'Fazenda Natal'. Mas acabou se tornando conhecida como os Campos do Jordão. O brigadeiro não chegou a conhecer sua nova aquisição - morreu antes disso, e seus herdeiros venderam seus diversos lotes para diferentes proprietários. (CAMPOS DO JORDÃO, 2007, p. 13-15)

A Estância Turística de Campos do Jordão está localizada a 167 km de distância da cidade de São Paulo e sua população é de 44.252 habitantes (Campos do Jordão, 2006). Situada a $1.700 \mathrm{~m}$ de altitude, é a cidade mais alta do Brasil. É limitada ao norte com os municípios mineiros de Itajubá, Pirangussu e Wenceslau Braz e, a leste, com Guaratinguetá, ao sul com Pindamonhangaba e a oeste com São Bento do Sapucaí, no Estado de São Paulo. (ver mapa das Regiões Administrativas e Metropolitanas do Estado de São Paulo em anexo)

Seu relevo acidentado é conseqüência de tremores de terra ocorrido entre 10 mil e 3 mil anos atrás, formando a região mais elevada do Estado de São Paulo: a Serra da Mantiqueira. O município tem $75 \%$ de áreas onduladas, $5 \%$ de áreas íngremes e $10 \%$ de zonas mais baixas, formadas pelas encostas da serra. (CAMPOS DO JORDÃO, 2007, p. 61)

Considerada Estância Climática, o clima de Campos do Jordão é o tropical de altitude, caracterizado por temperaturas amenas no verão (entre $20^{\circ}$ e $25^{\circ} \mathrm{C}$ ). No inverno, o mês de julho apresenta a menor média de temperatura mensal correspondente a $8,2^{\circ} \mathrm{C}$. A média mínima diária é inferior a $4^{\circ} \mathrm{C}$ durante o inverno, descendo a $1,8^{\circ} \mathrm{C}$ no solstício de julho. José Setzer classificou o 
clima de Campos como mesotérmico, ou seja, costuma oferecer verões brandos e sem estação seca. (CAMPOS DO JORDÃO, 2007, p. 75)

Alberto Loefgren anotou, em 1898, que a vegetação de Campos do Jordão no meio de uma região tropical era a prova da compensação da latitude pela altitude. Em Campos do Jordão predominam dois tipos de vegetação: a de mata e a campestre. Duas espécies de coníferas dominam a paisagem: a Araucaria podocarpus e a Araucaria angustifolia.



Figura 4: Entrada principal do município de Campos do Jordão, onde se localiza a Secretaria de Turismo. Estaríamos entrando na Suíça?

$\mathrm{Na}$ entrada (fig. 4), onde se localiza um escritório da Secretaria de Turismo, o atendente declarou não receber nenhuma informação do PECJ porque "eles não passam nada para gente". O pórtico (foto 1) de padrão arquitetônico que "corre o risco da aberração, tal a vontade de ser suíço" (YÁZIGI, 2002, P. 102). Segundo Gallo Junior (2000, p. 97-98), a cidade de Campos do Jordão recebeu cerca de 3.667 .392 pessoas no ano de 1997. 
A "Estrada do Horto" é a principal ligação da cidade com o Parque. Como podemos observar nas figuras 5 e 6 , apesar da promessa de término das obras no final do ano de 2006, até agora podemos observar a existência de muitos buracos e falta de sinalização na rodovia.

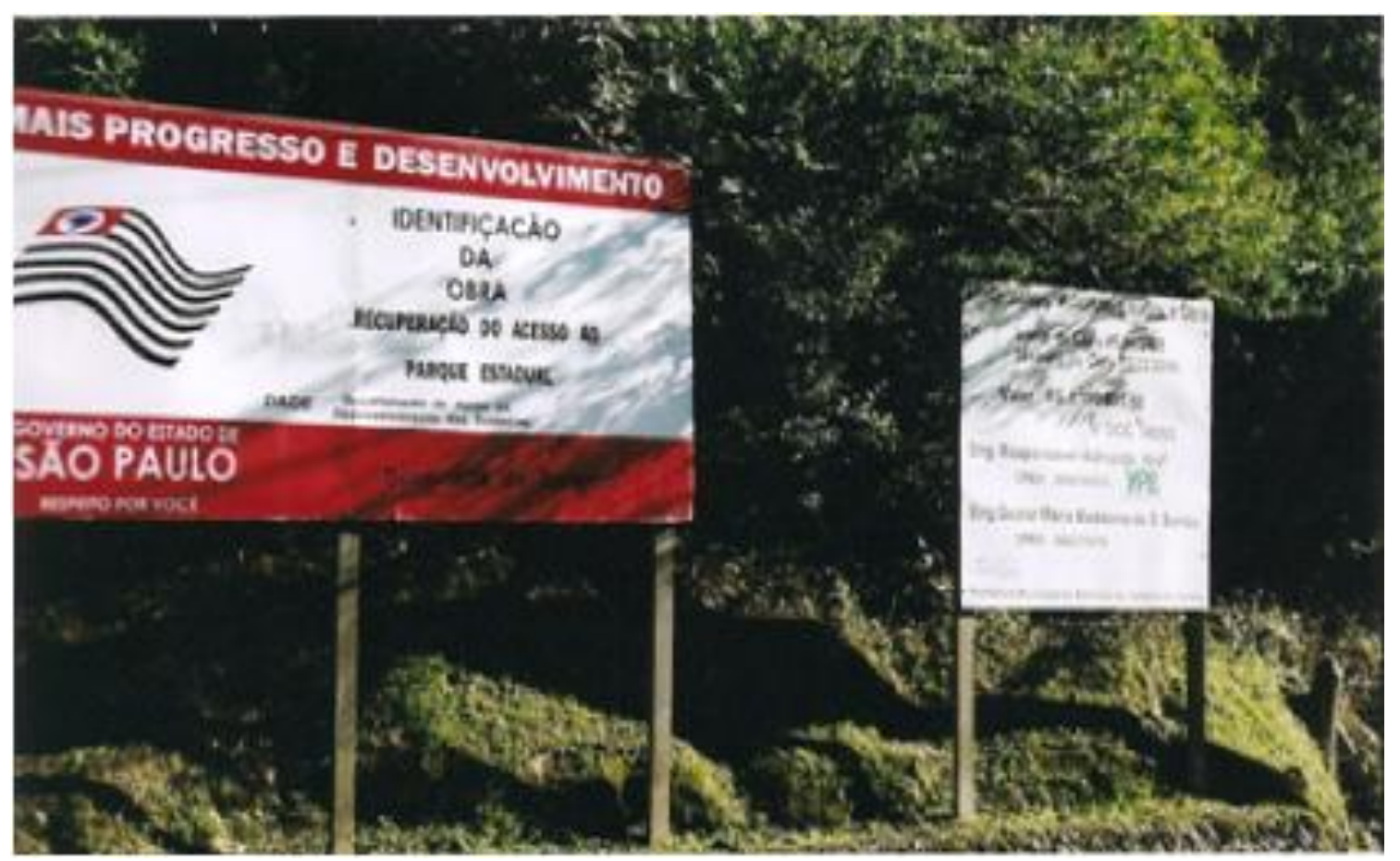

Figura 5: Identificação da Obra "Recuperação do Acesso ao Parque Estadual". A placa ao lado indica o valor da obra $(R \$ 1.199 .605,50)$ e a data de término $(05 / 12 / 2006)$. 


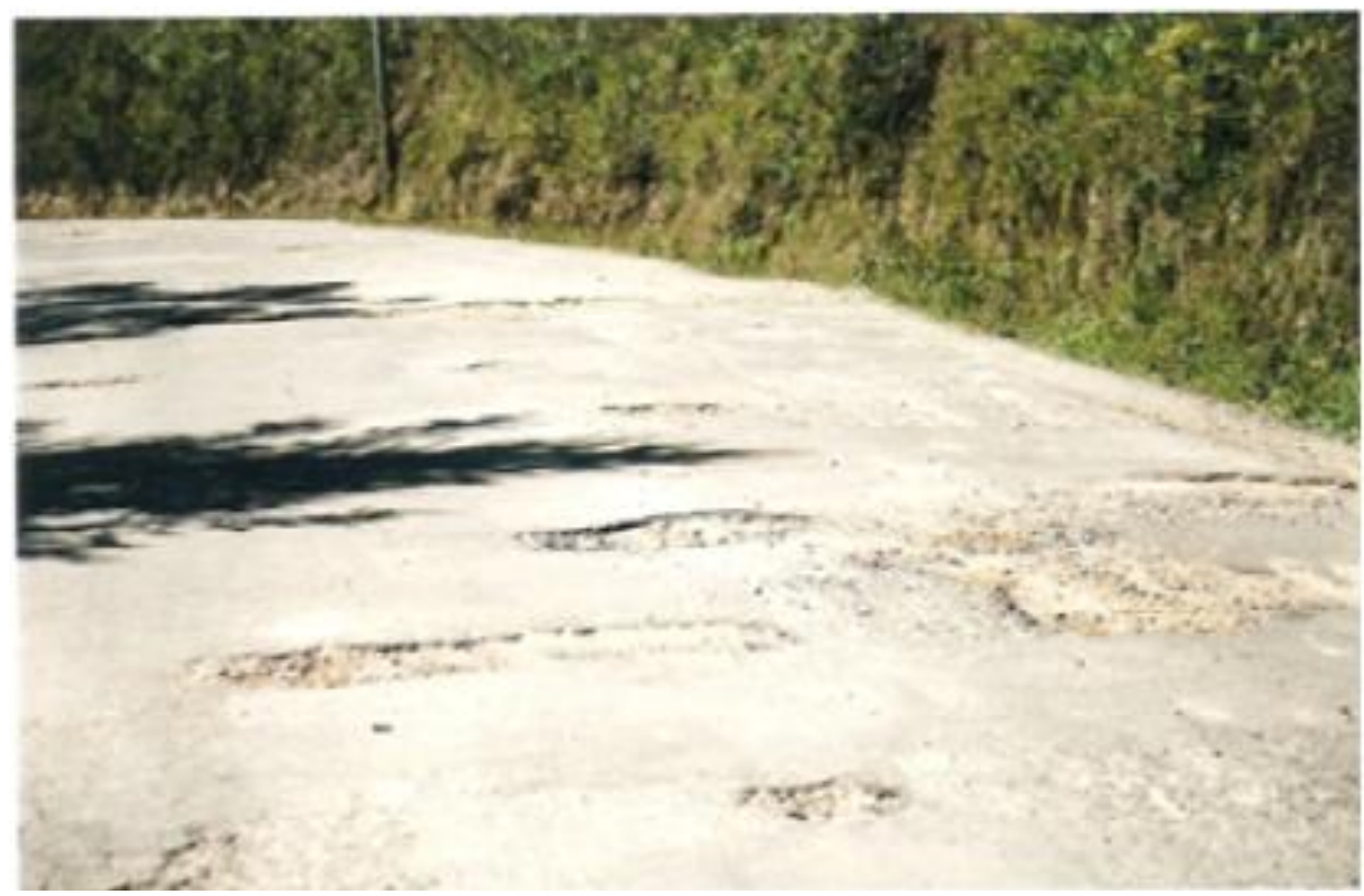

Figura 6: Alguns dos muitos buracos encontrados na "Estrada do Horto".

\subsection{O Parque Estadual de Campos do Jordão}

Criado em 27 de março de 1941, pelo Decreto Estadual no 11.908, o Parque Estadual de Campos do Jordão corresponde a quase 1/3 do município de Campos do Jordão, com uma área de 8.286,30 ha.

É uma unidade do Instituto Florestal e administrado por tal entidade. Um plano de manejo foi publicado em dezembro de 1975 e está sendo atualizado.

Segundo Marcondes (2007), o Parque Estadual de Campos do Jordão é "considerado um modelo para os trabalhos de manejo de áreas naturais e sempre pioneiro nestas questões".

A grande parte dos recursos financeiro do parque são provenientes da comercialização de madeita de Pinus sp, que é vendida à Prefeitura. A taxa de visitação do parque também gera importante receita. Segundo Neto, Timoni e Pires (2003, p. 325), a receita do PECJ é estimada em novecentos mil reais, onde os autores verificam a possibilidade de sua auto-sustentação. A grande 
parte desta receita é usada para pagar serviços de terceiros, principalmente relacionados à vigilância.

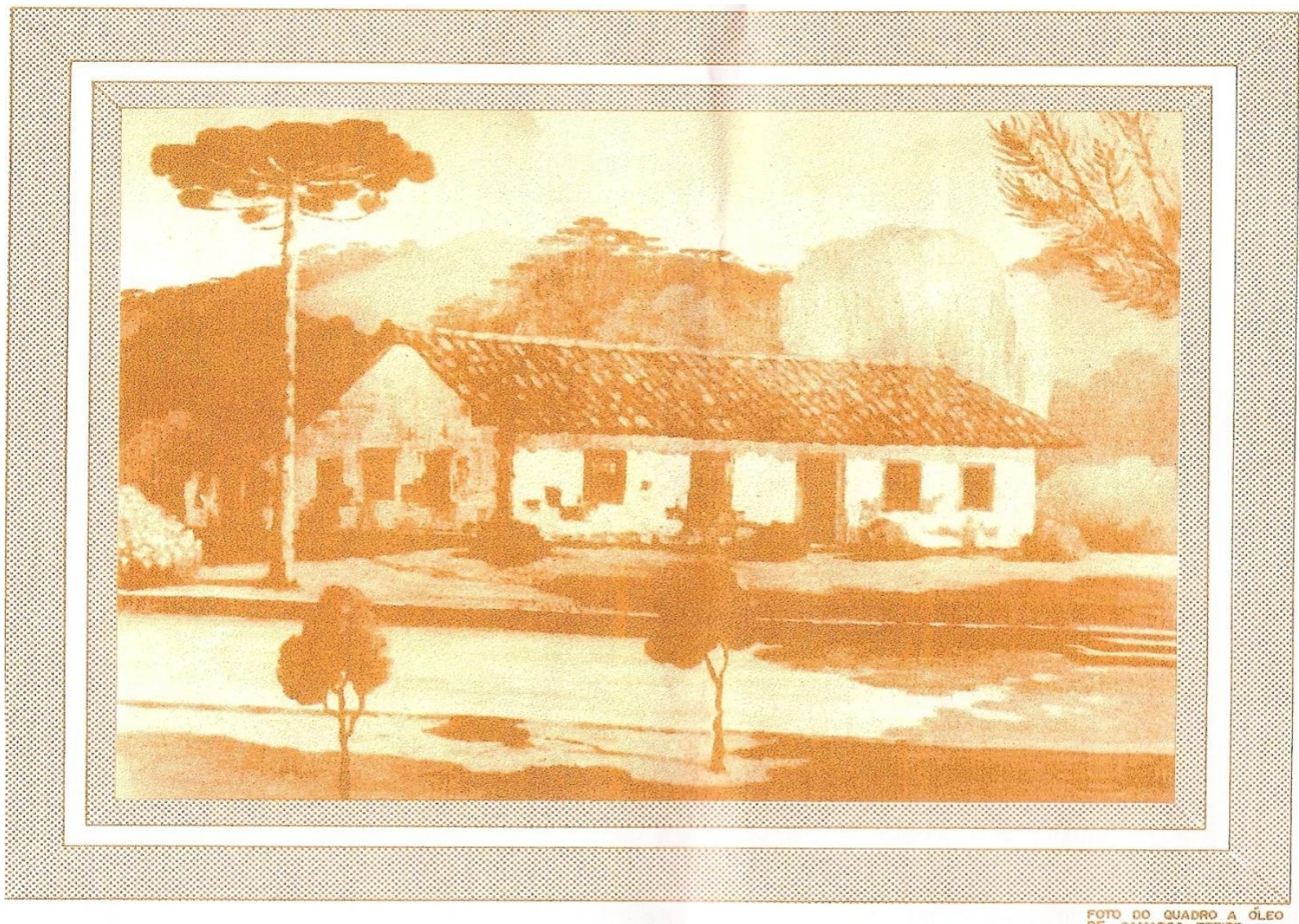

Figura 7: Primeira residência construída em 1855 no local denominado Fazenda da Guarda

A figura 7 faz referência à primeira residência construída na área do Parque.

O portal de entrada e as placas de sinalização (figuras 8 e 9) não interagem com a paisagem e não apresentam ou são apropriadas ao desenho universal. As placas de sinalização, em todo o parque, são de difícil leitura. Não apresenta sistema de identidade visual adequado, ou seja, não há uma padronização de tipos de letras, cores e materiais resistentes às intempéries e simbologia adequada à identificação dos locais específicos de visitação dentro 
do parque. Vale acrescentar que na estrada de acesso tais equipamentos também não foram contemplados.

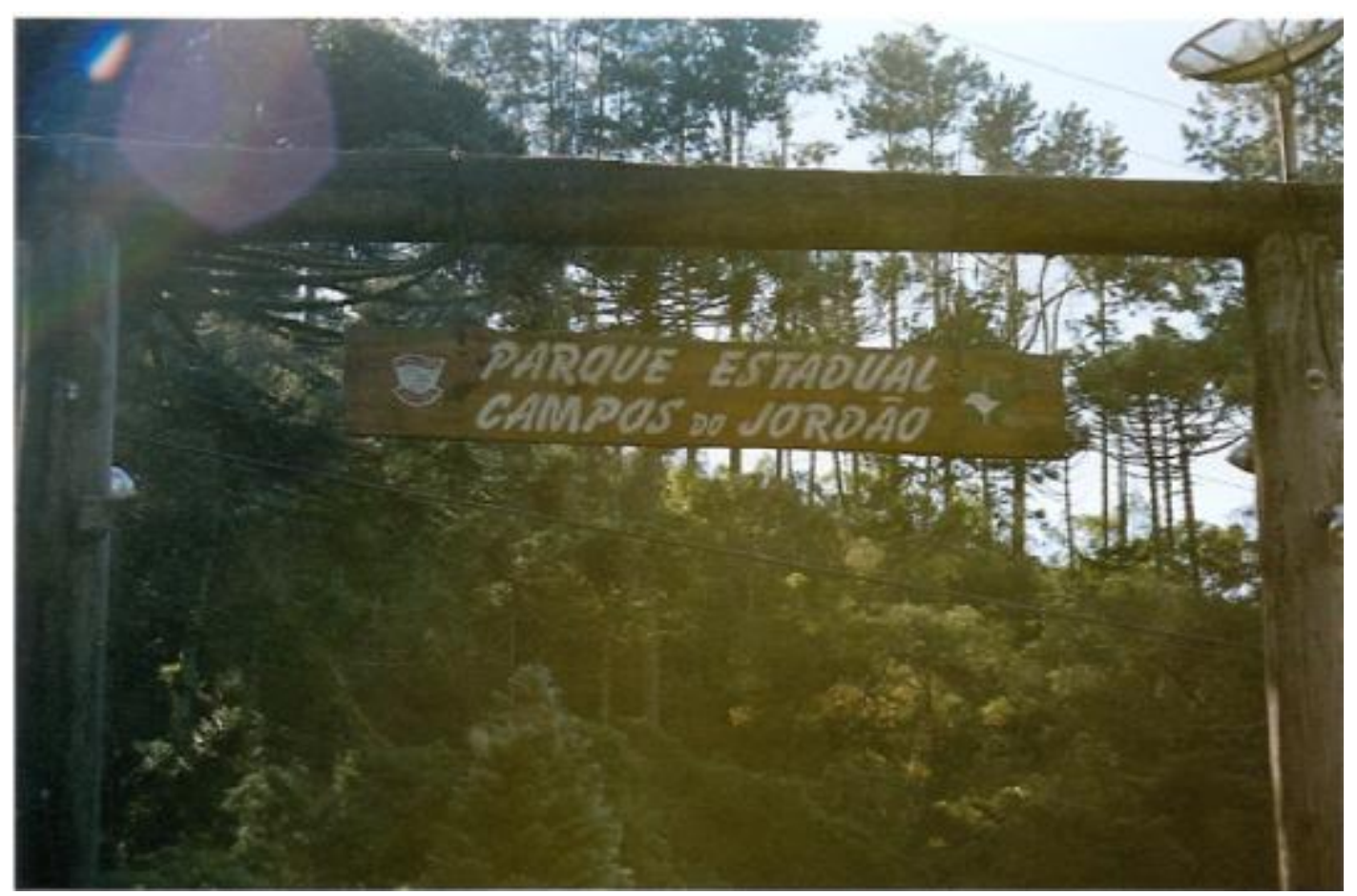

Figura 8: Portal de entrada do Parque

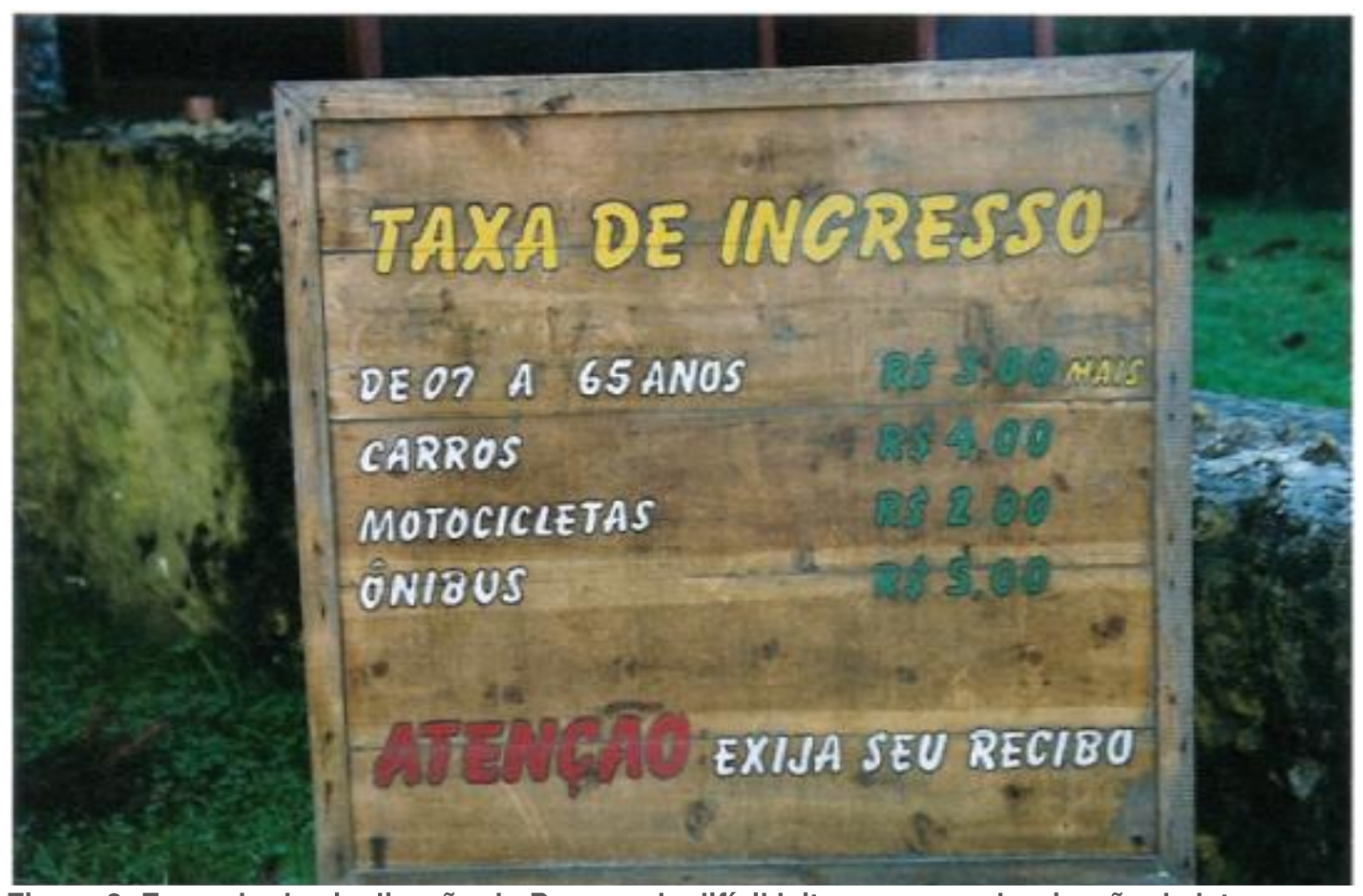

Figura 9: Exemplo de sinalização do Parque, de difícil leitura, sem padronização de letras ou símbolos. 
O símbolo do parque (figura 10) não retrata um padrão de identidade visual, sendo, portanto, um objeto a mais de revisão. Além de não sintetizar as qualidades visuais e paisagísticas do parque, apresentando elementos desconexos e aleatórios que não retratam a magnitude do PECJ para o turista.

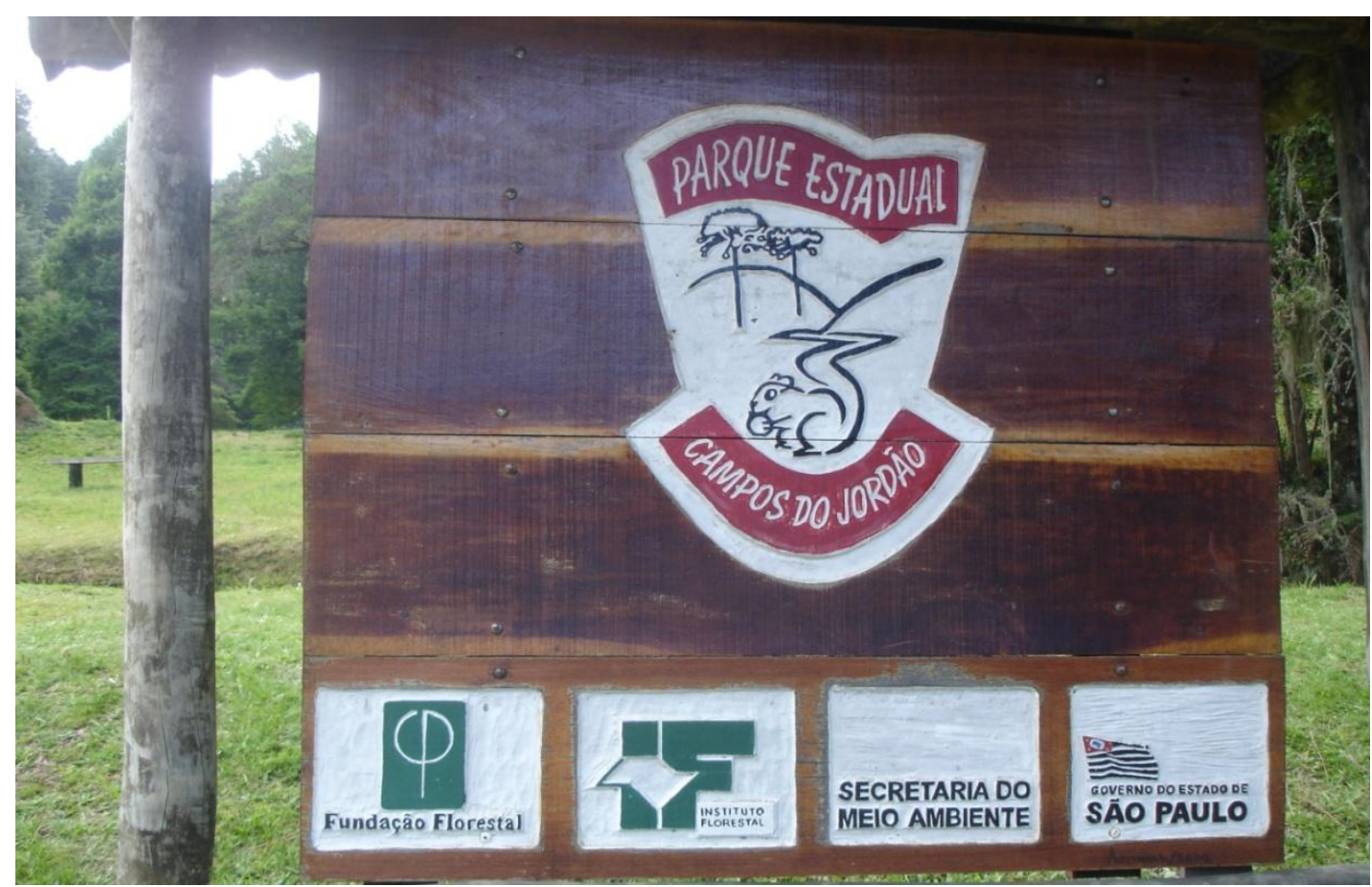

Figura 10: Símbolo do PECJ

Em sua área, o Parque apresenta os seguintes serviços:

Os galpões (figuras 11 e 12) destinados à venda de artesanato, onde a maioria do estoque de suas mercadorias não é produzida em Campos do Jordão. Porém, alguns objetos de artesanato local (figura 13), executados com pequenas toras de araucária de poda ou encontradas na floresta apresentariam potencial de a venda de artesanato regional se houvesse ali orientação devida. Para tal o parque poderia ser provido de locais para oficinas de execução de artesanato. Ainda neste equipamento não foram observadas a venda de artefatos executados em lã e o chocolate que são característicos de Campos do Jordão. Acrescente-se que as instalações são precárias, no qual se observou a falta de proteção nas paredes de fechamento, as instalações 
elétricas em más condições, a visibilidade e o volume de estoque é comprometida pela cubagem métrica subdimensionada do equipamento.

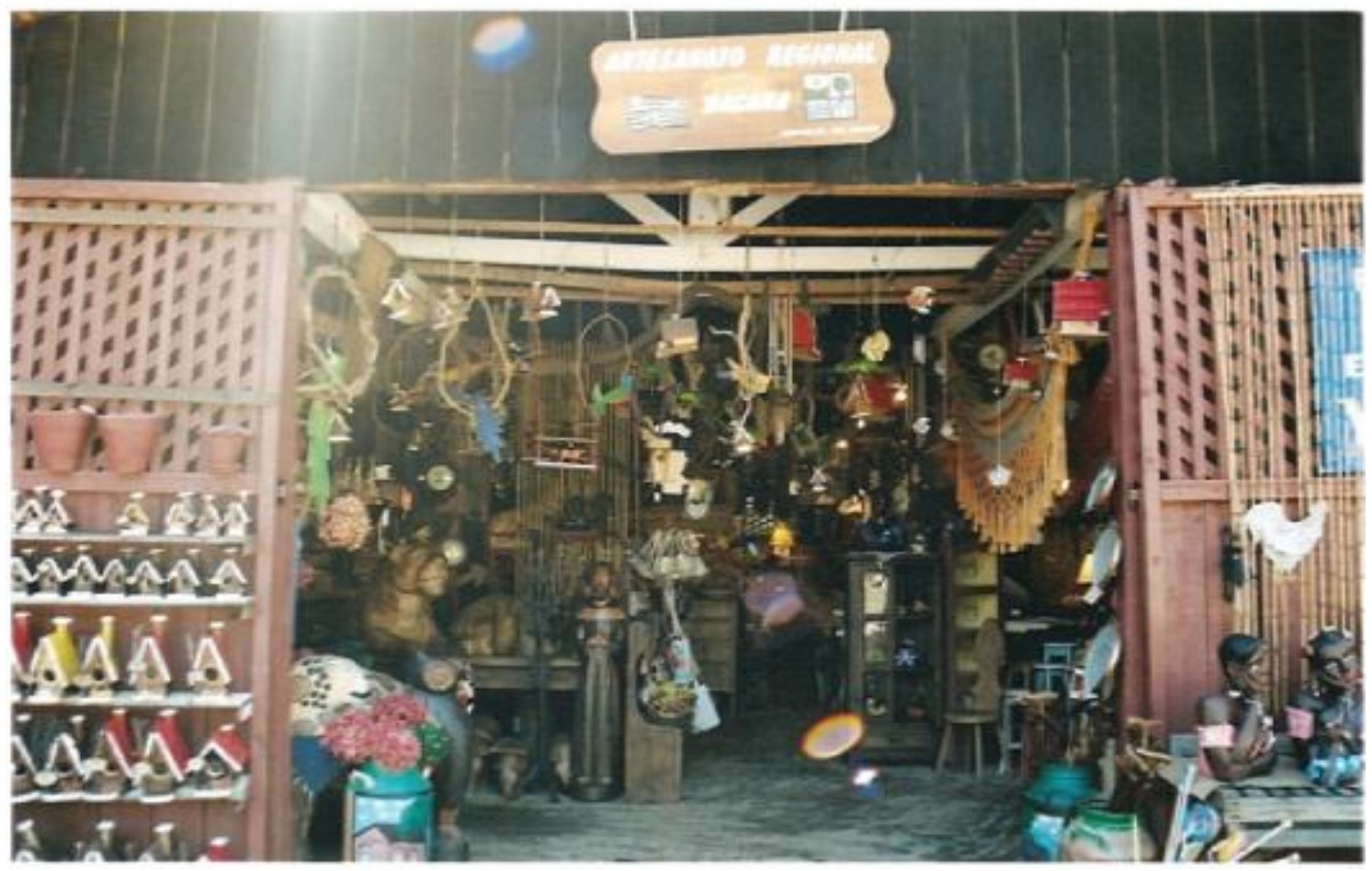

Figura 11: Galpão de artesanato - nota-se a desorganização

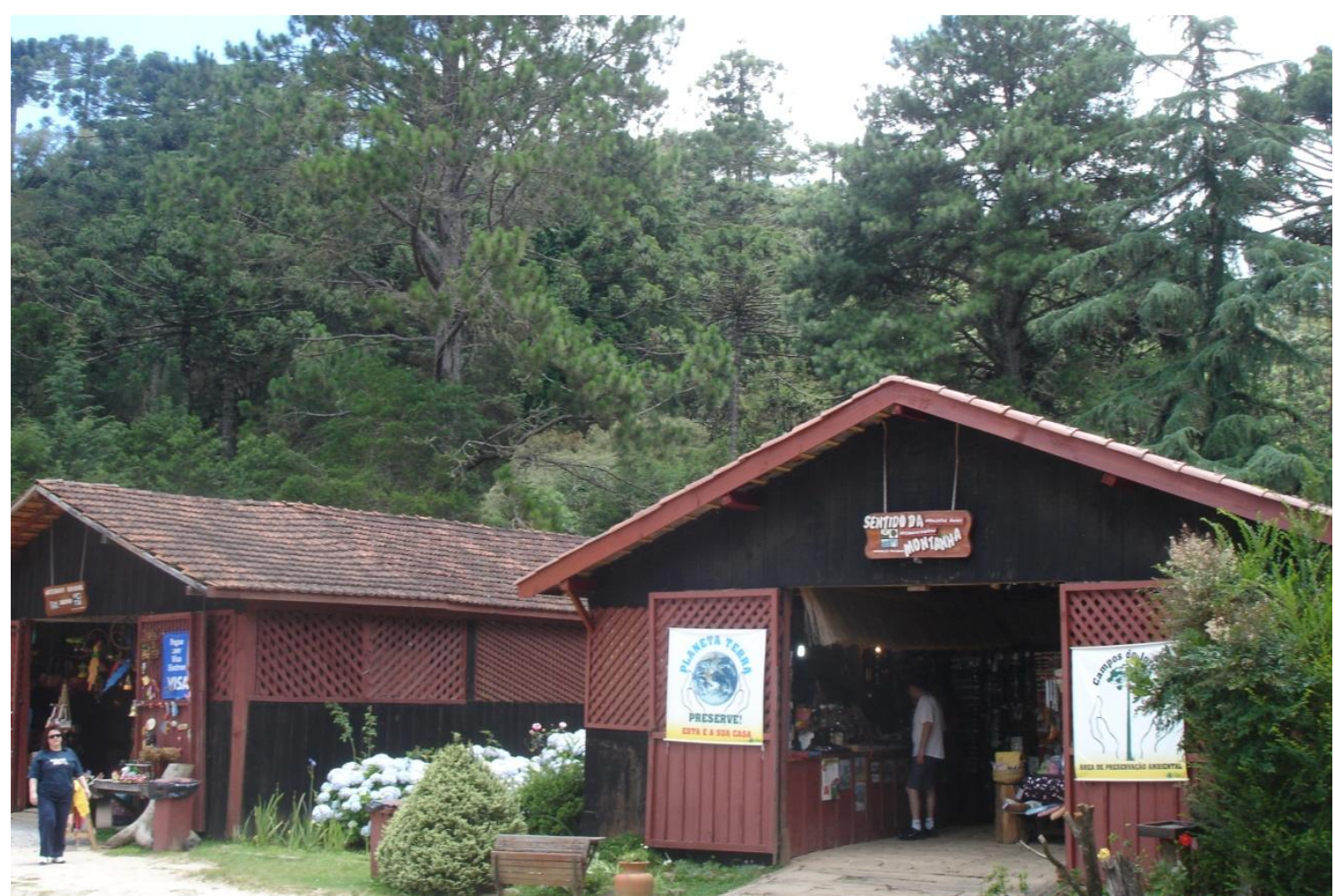

Figura 12: Galpões de artesanato 




Figura 13: Artesanato local, executados com pequenas toras de araucária

As áreas para recreação (figura 14), os playgrounds, são obsoletos, desinteressantes e até perigosos, pois se observa a falta de manutenção. São os tradicionais arranjos de gangorras, balanços, entre outros objetos superados, pouco interativos e que podem causar acidentes. 


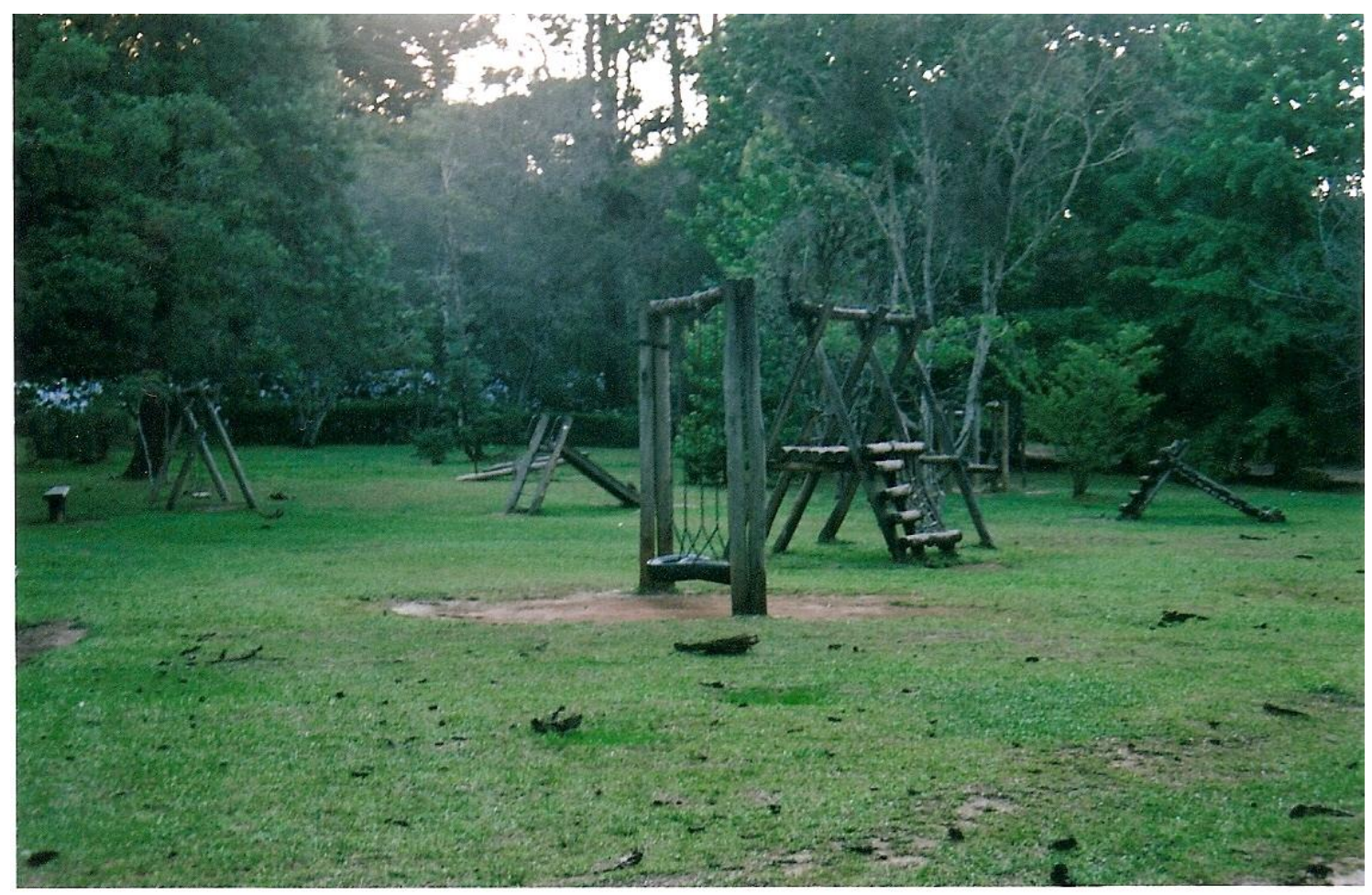

Figura 14: Área para recreação

O Viveiro de mudas (figura 15), as estufas com espécies exóticas e nativas se apresentam desorganizadas, sem um local de entrada apropriado e com uma climatização deficiente. Acrescente-se que esse tipo de equipamento, em um parque, deveria ter uma construção que além de apropriada, deveria exercer um marco referencial no conjunto do quadro edificado. 


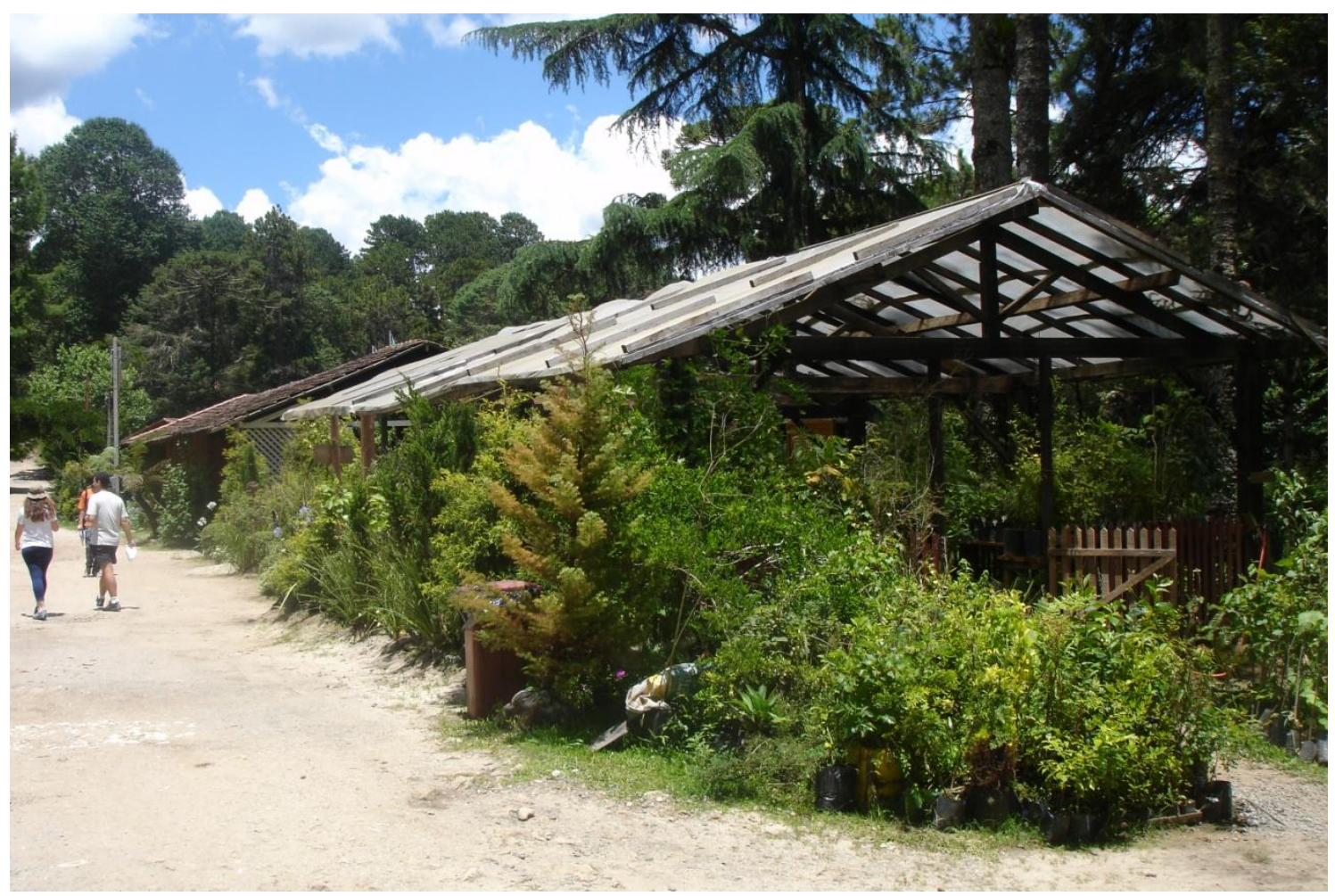

Figura 15: Viveiro de mudas, desorganizado e sem entrada apropriada

Os sistemas de trilhas (figura 16) que são sete no total e se apresentam com sinalização deficiente ou inexistente (figuras 17, 18 e 19).

Extraido de Folhetos do If (2002)

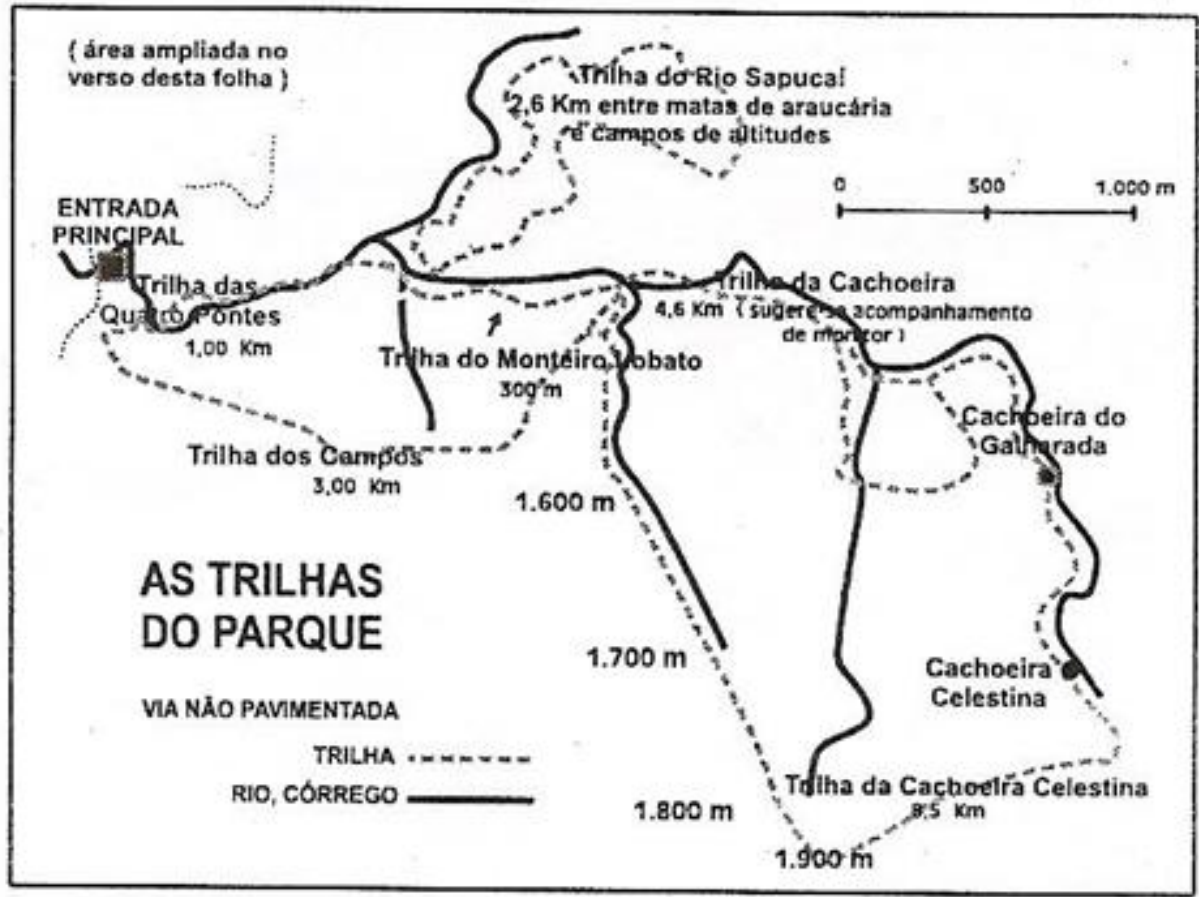

Figura 16: Mapa das trilhas do PECJ 


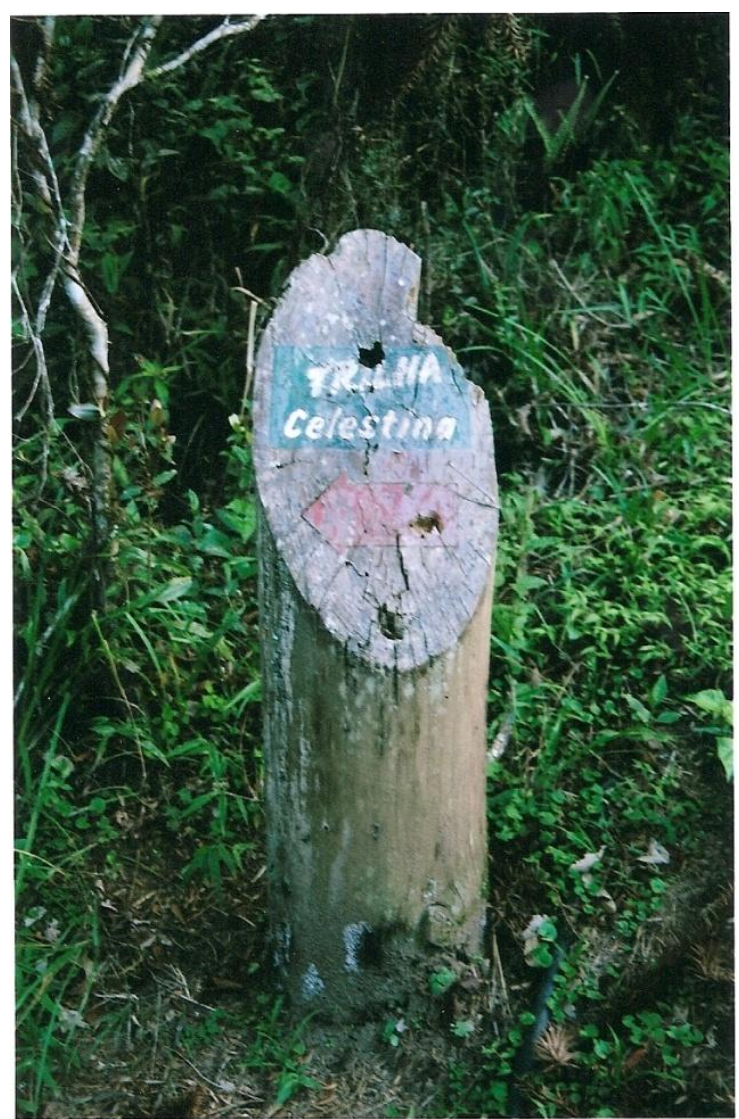

Figura 17: Sinalização deficiente nas trilhas

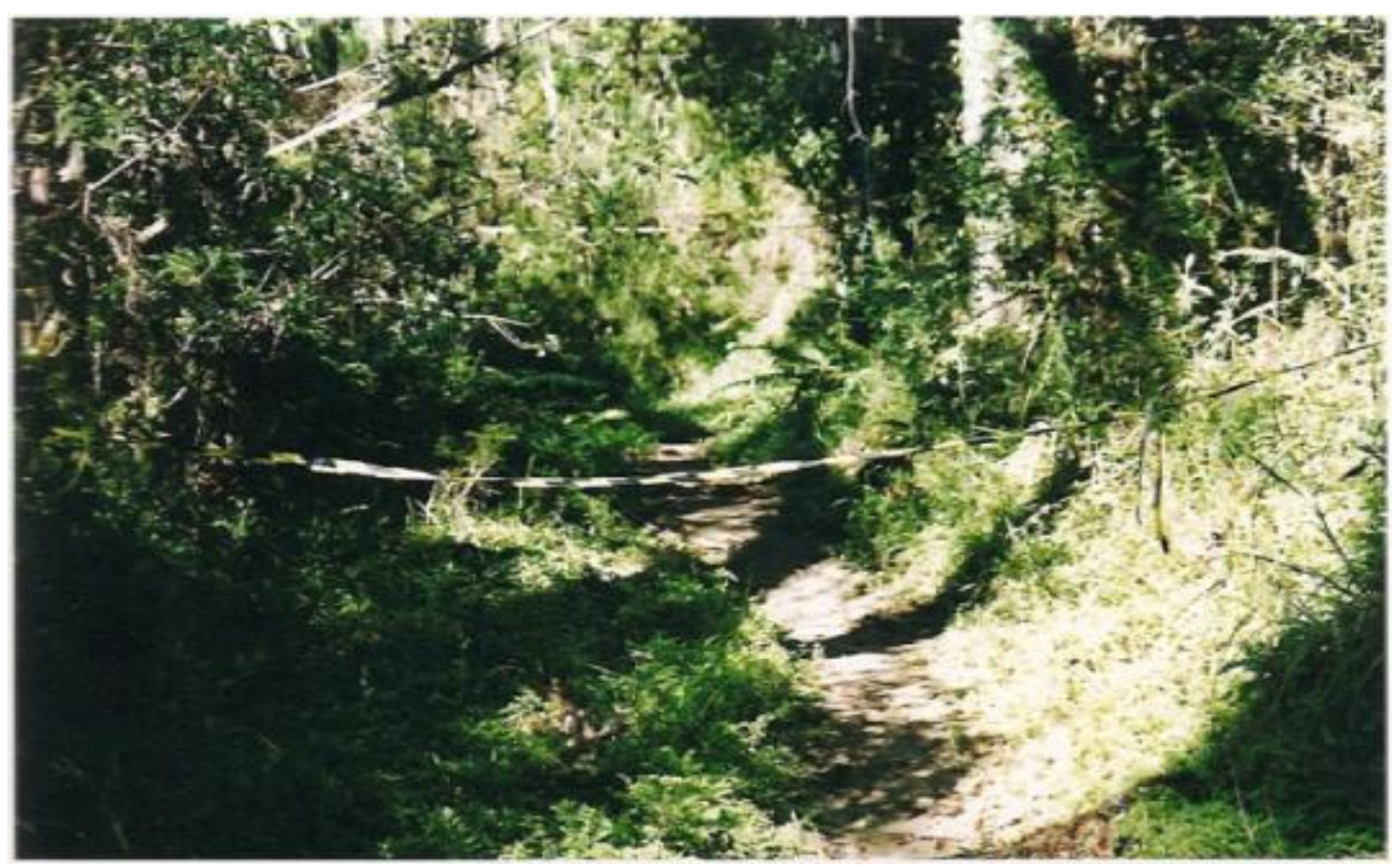

Figura 18: Foto tirada em março de 2007, como conseqüência das fortes chuvas, a trilha da Celestina foi fechada. Apenas uma pequena fita indicava seu fechamento. 


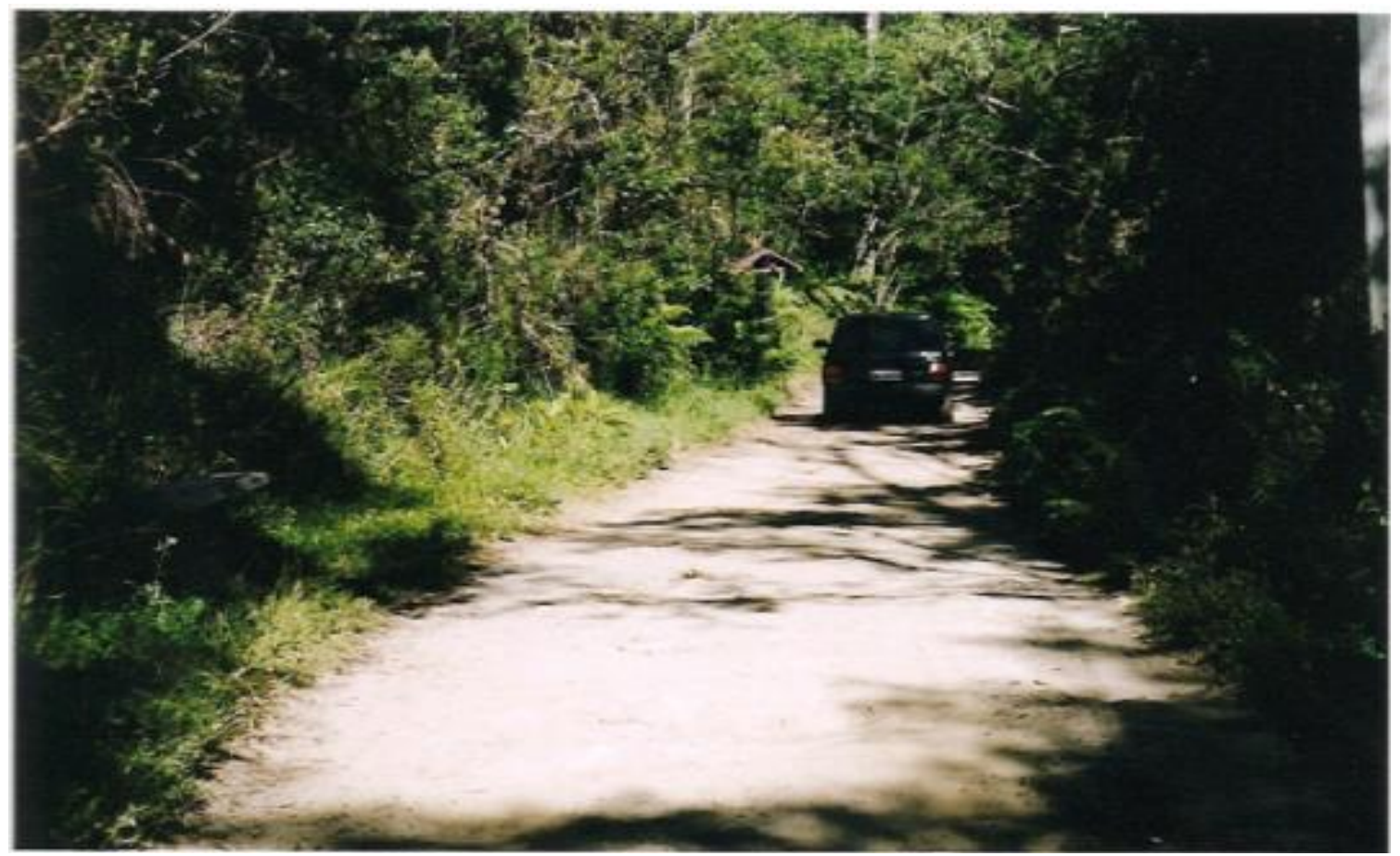

Figura 19: A presença de carro na trilha da Cachoeira. Faltam informações sobre a presença de automóveis na trilha. 
As instalações e recintos da lanchonete (figura 20), também se apresentam sem nenhuma espécie de diálogo visual com a paisagem, escondendo os aspectos visuais do parque e a falta de acessibilidade constante em todos os equipamentos do parque.

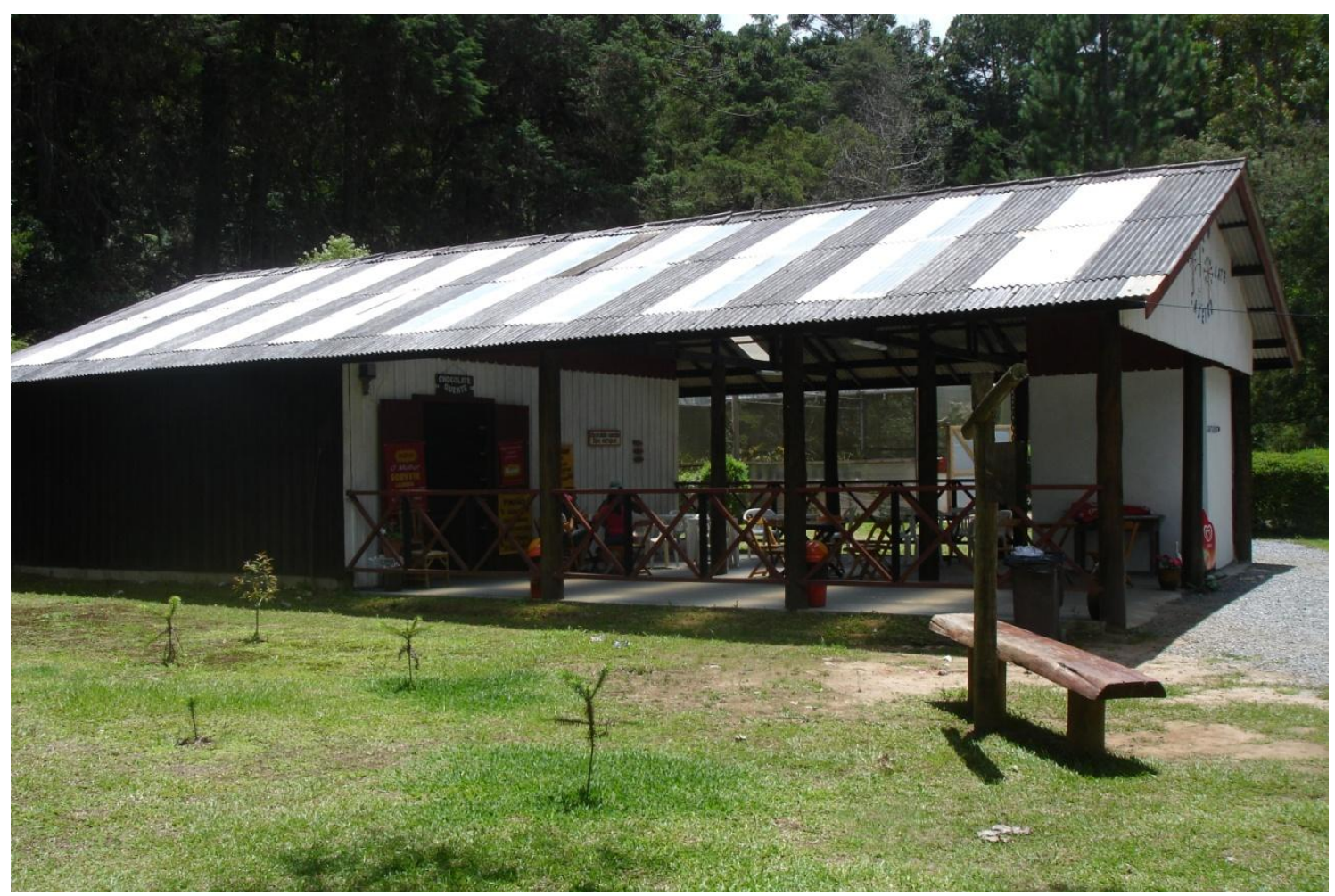

Figura 20: Lanchonete do PECJ, com raras exceções as coberturas dos equipamentos são inadequadamente cobertas com fibro cimento.

No Posto de Saúde e Fraldário (figuras 21 e 22), percebe-se a falta de telhas na sala de espera, uma varanda sem parede de proteção, onde supostamente chove dentro e nas salas internas. Mal conservadas, há paredes apresentando enormes manchas de umidade. 




Figura 21: Falta de telhas na sala de espera do posto de saúde

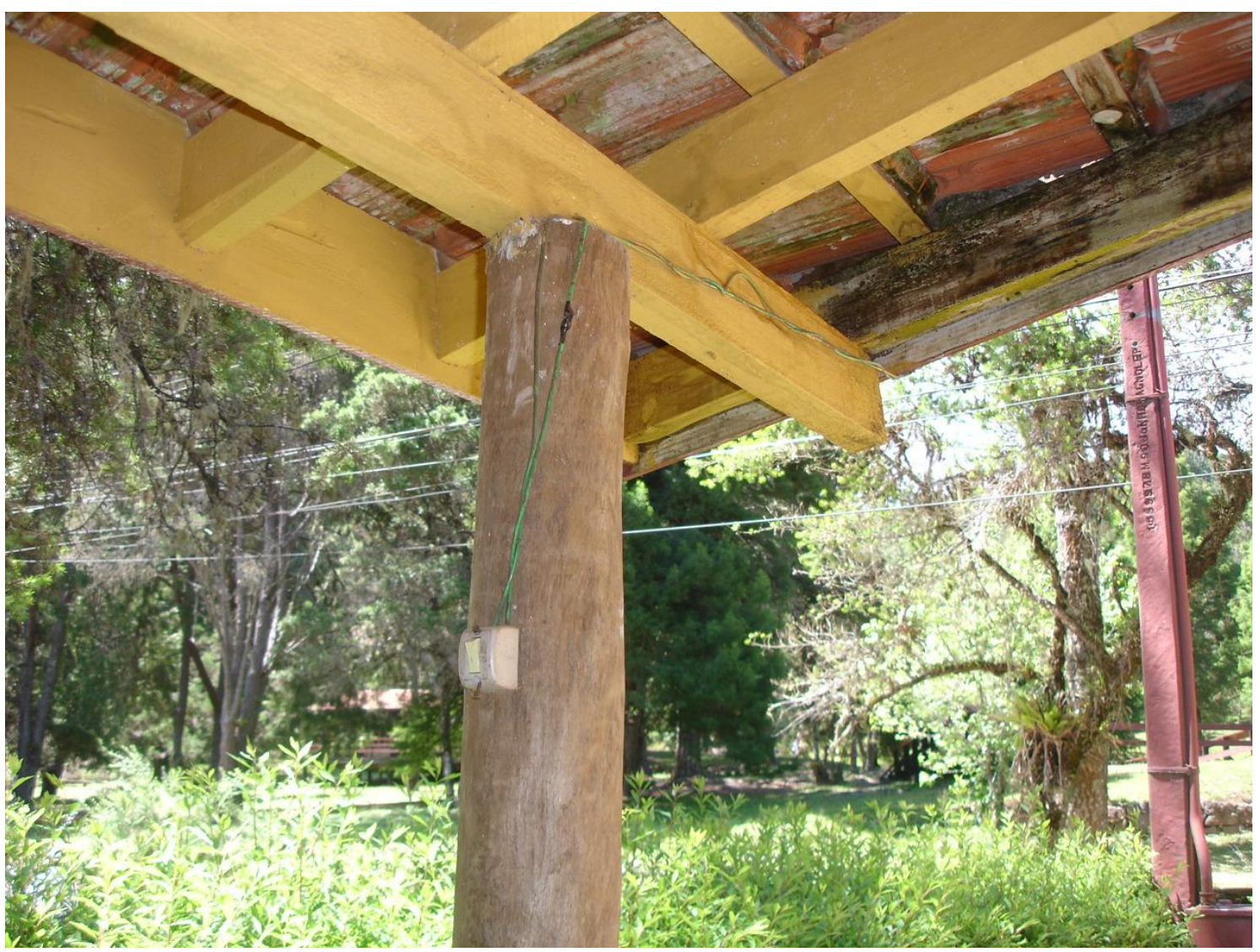

Figura 22: Instalações elétricas precárias no posto de saúde 
Os sanitários externos (figuras 23 e 24), sem acessibilidade a pessoas especiais, têm ventilação precária e instalações elétricas com fiações aparentes.



Figura 23: Sanitário externo, sem acessibilidade

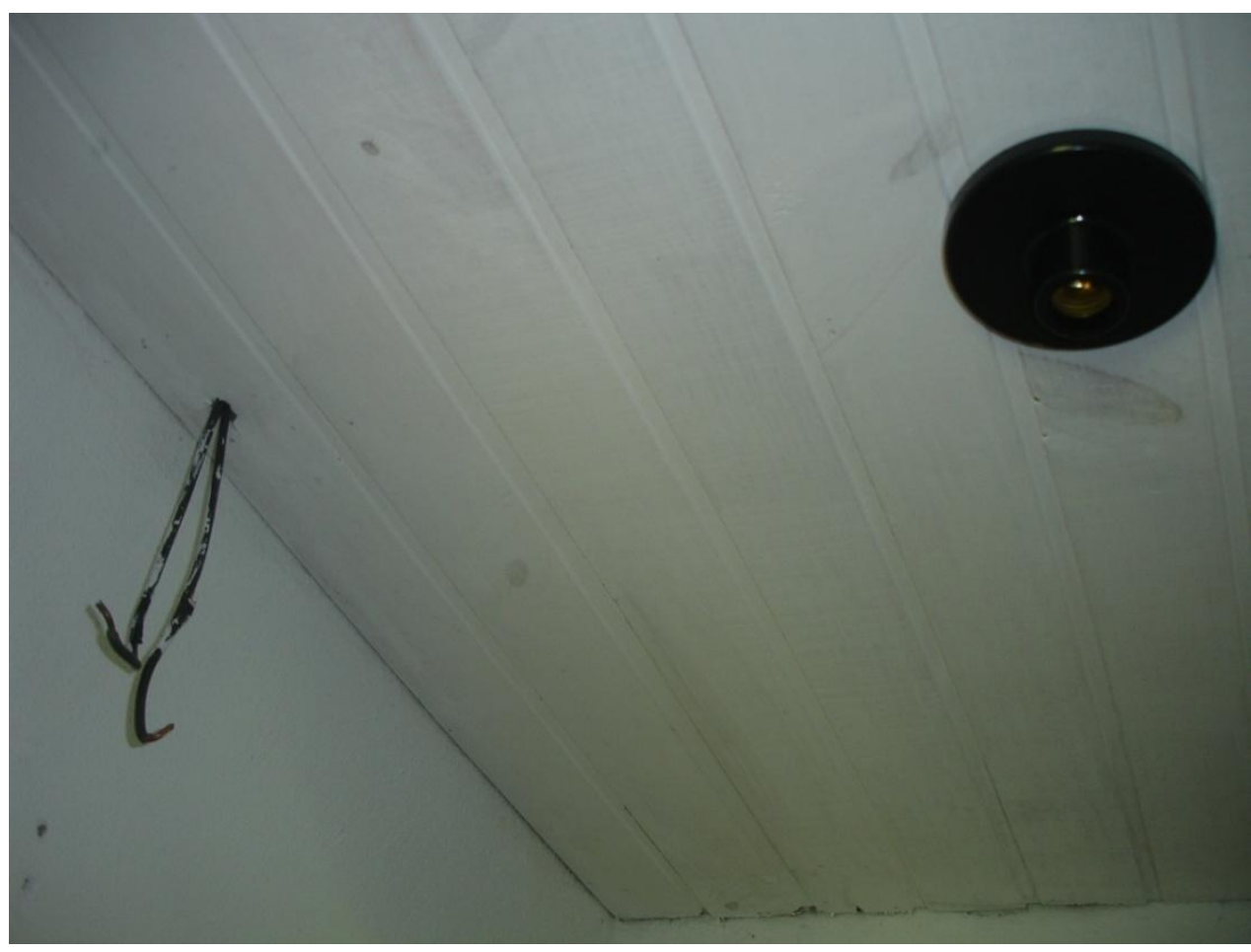

Figura 24: Fiação aparente no sanitário externo 
No posto telefônico (figura 25) não se encontram informações para ligações internacionais. Há também neste recinto um mapa pálido e precário da malha urbana e dos pontos de interesse da cidade de Campos do Jordão (figura 26). Com respeito à falta de conservação deste equipamento, a responsabilidade pode ser atribuída a ambas as entidades, ou seja, o PECJ e à empresa telefônica responsável.

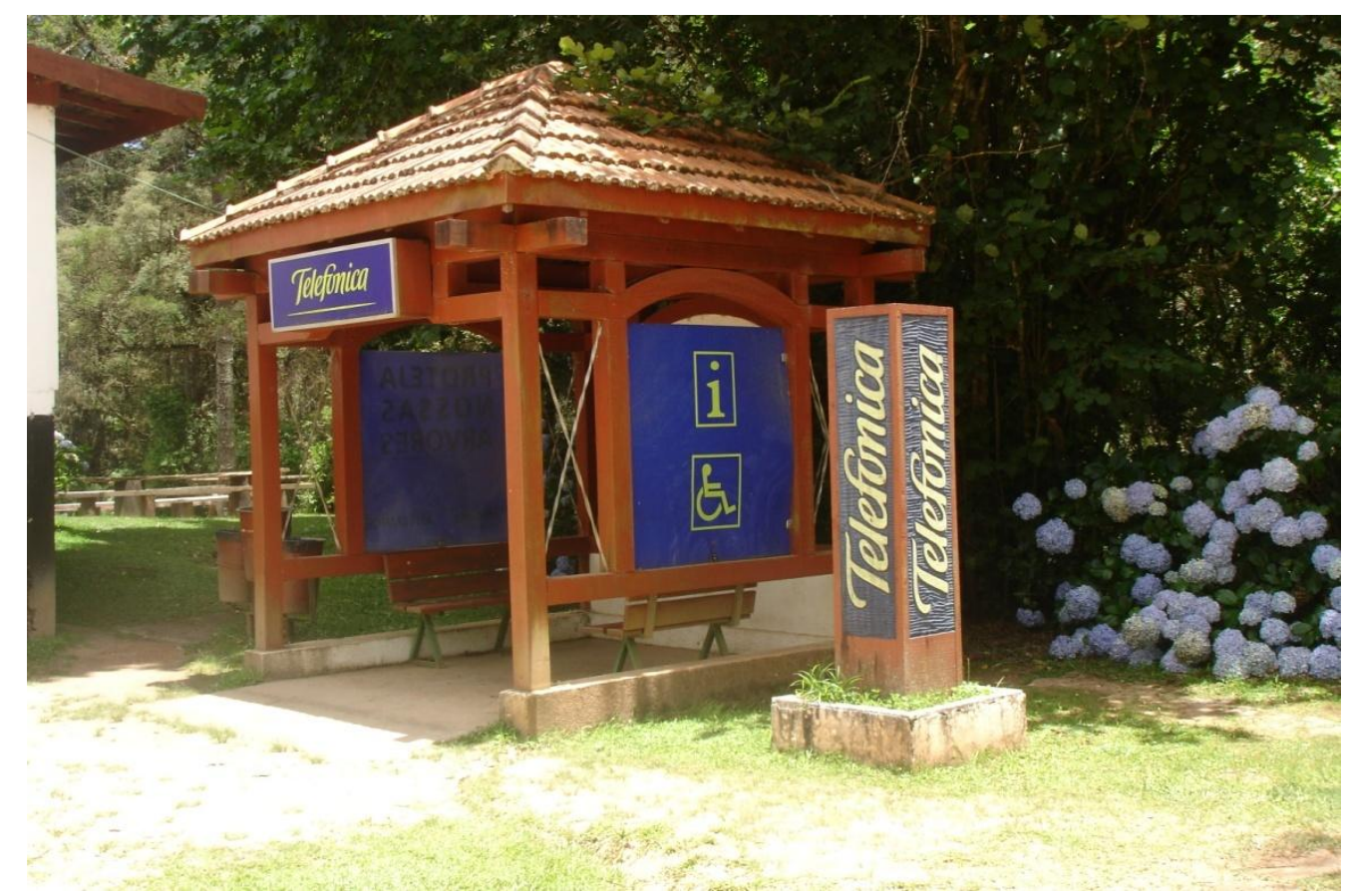

Figura 25: Posto telefônico

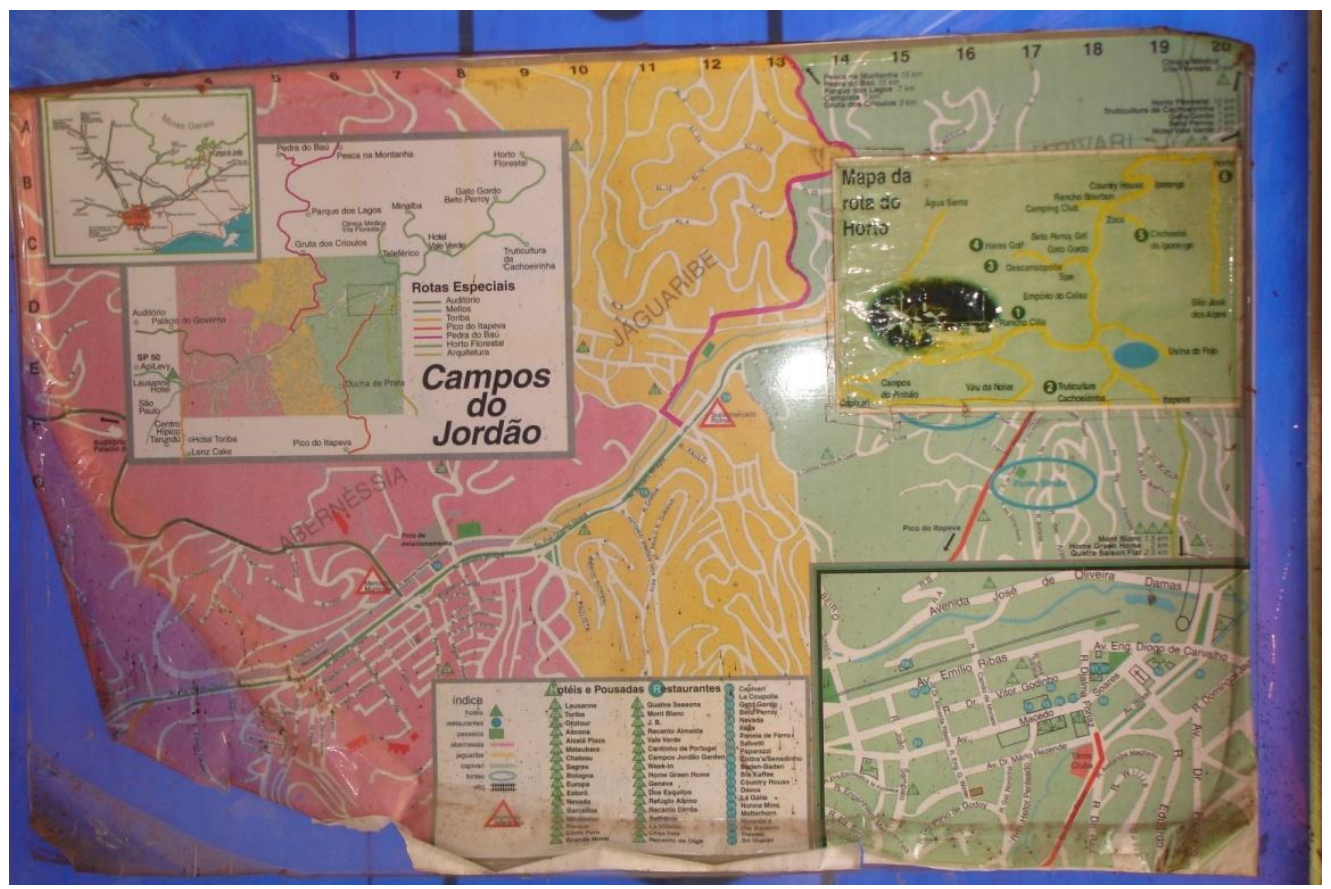

Figura 26: Mapa pálido e precário da malha urbana e dos pontos de interesse da cidade de Campos do Jordão 
O estacionamento (figura 27), onde falta sinalização e, como conseqüência é extremamente desorganizado. Não existem vagas veículos de pessoas especiais e para vans. Outro aspecto que se pode colocar em discussão é se um estacionamento se ajusta com a idéia de parque. Talvez fosse apropriado mantê-lo próximo, mas à margem do parque.

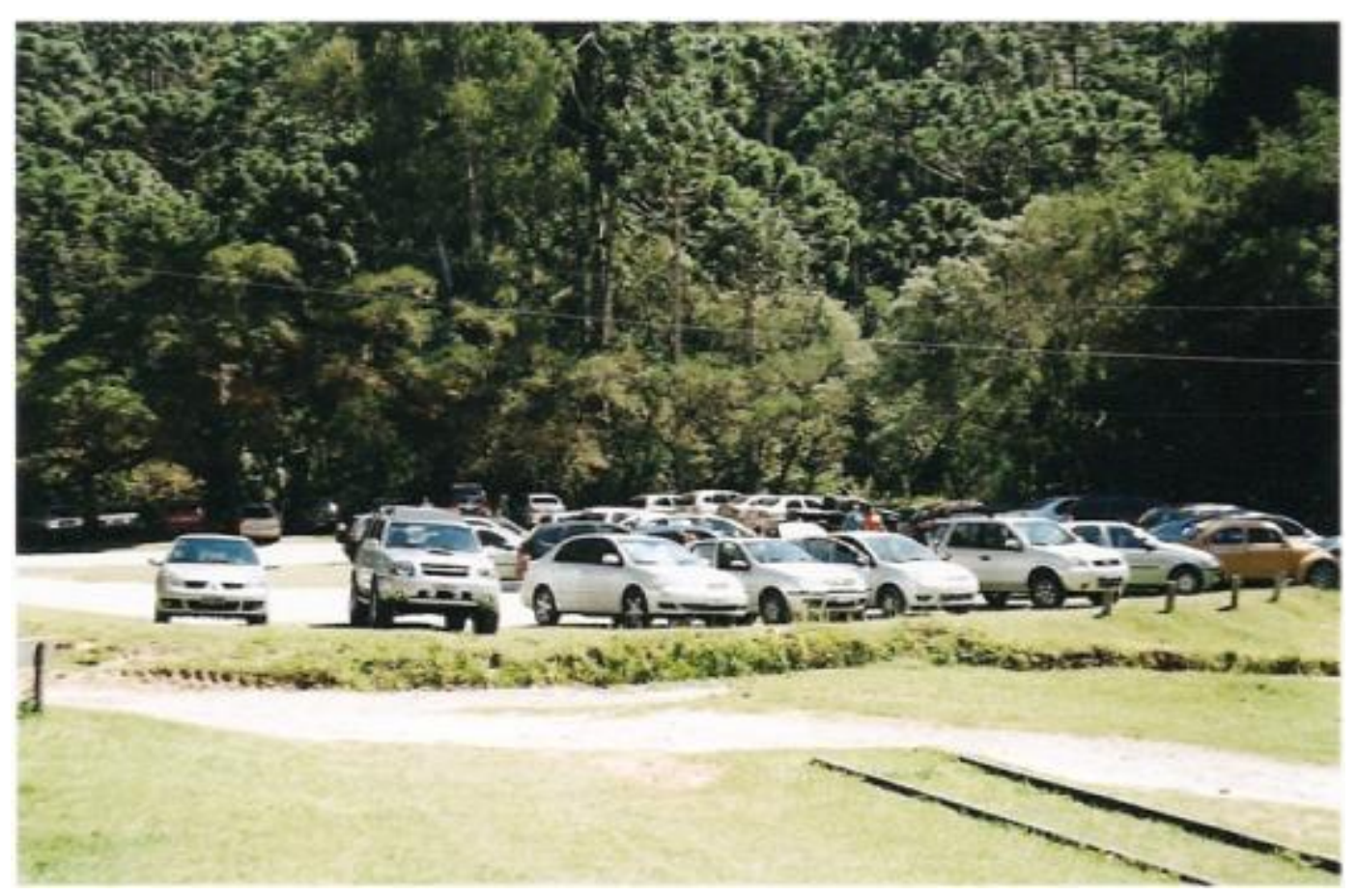

Figura 27: Estacionamento do PECJ, desorganizado e sem sinalização 
O recinto que abriga a antiga serraria também se apresenta como um equipamento de instalações precárias, com altos riscos de acidentes, pois as de telhas metálicas estão corroídas em quase em toda sua extensão (figura 28). A estrutura, pilares, vigas, terças e ripas do galpão estão envelhecidas e deterioradas e, como é recorrente em todos os equipamentos, a fiação elétrica está exposta e desprotegida (figura 29).

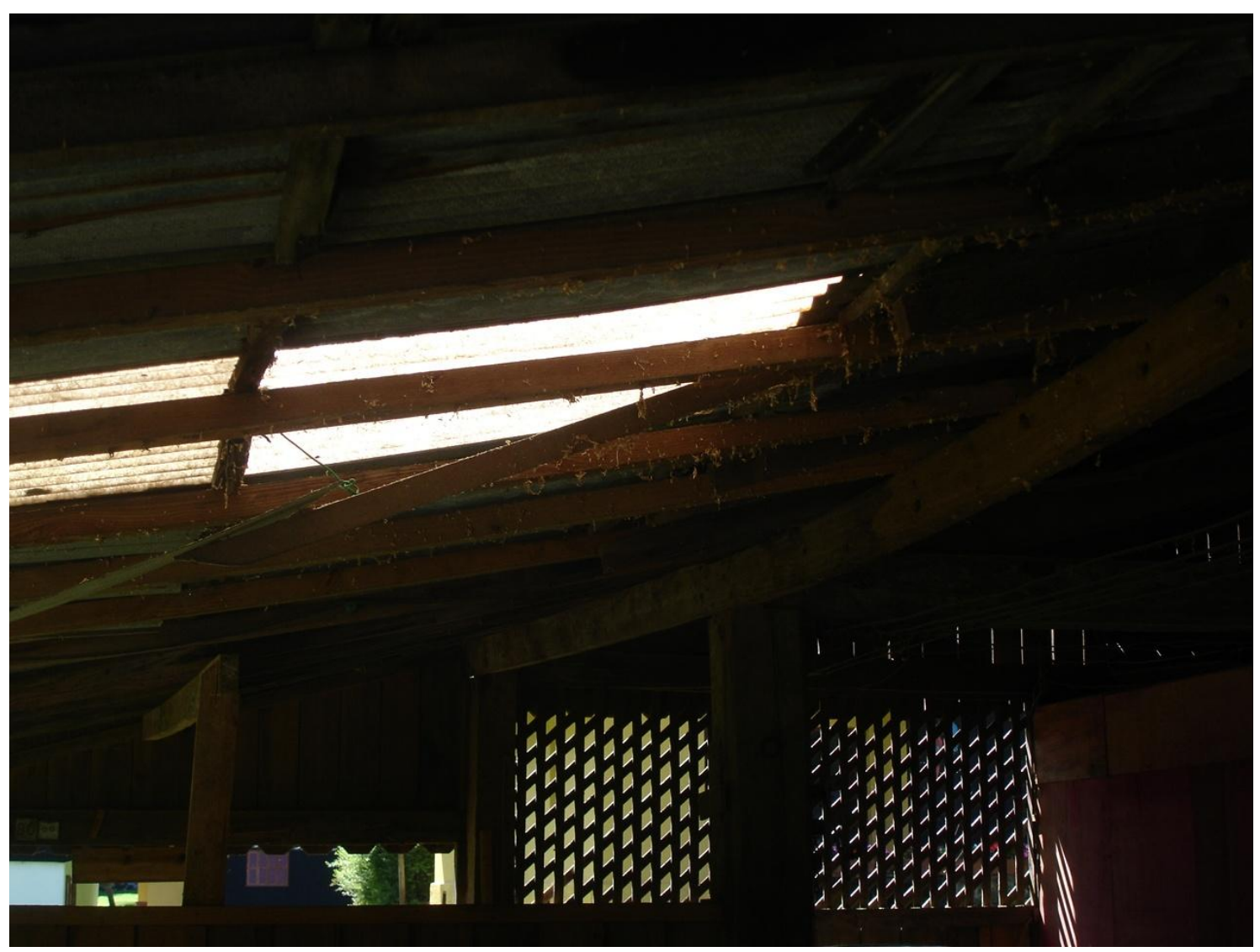

Figura 28: Telhas metálicas corroídas na serraria 


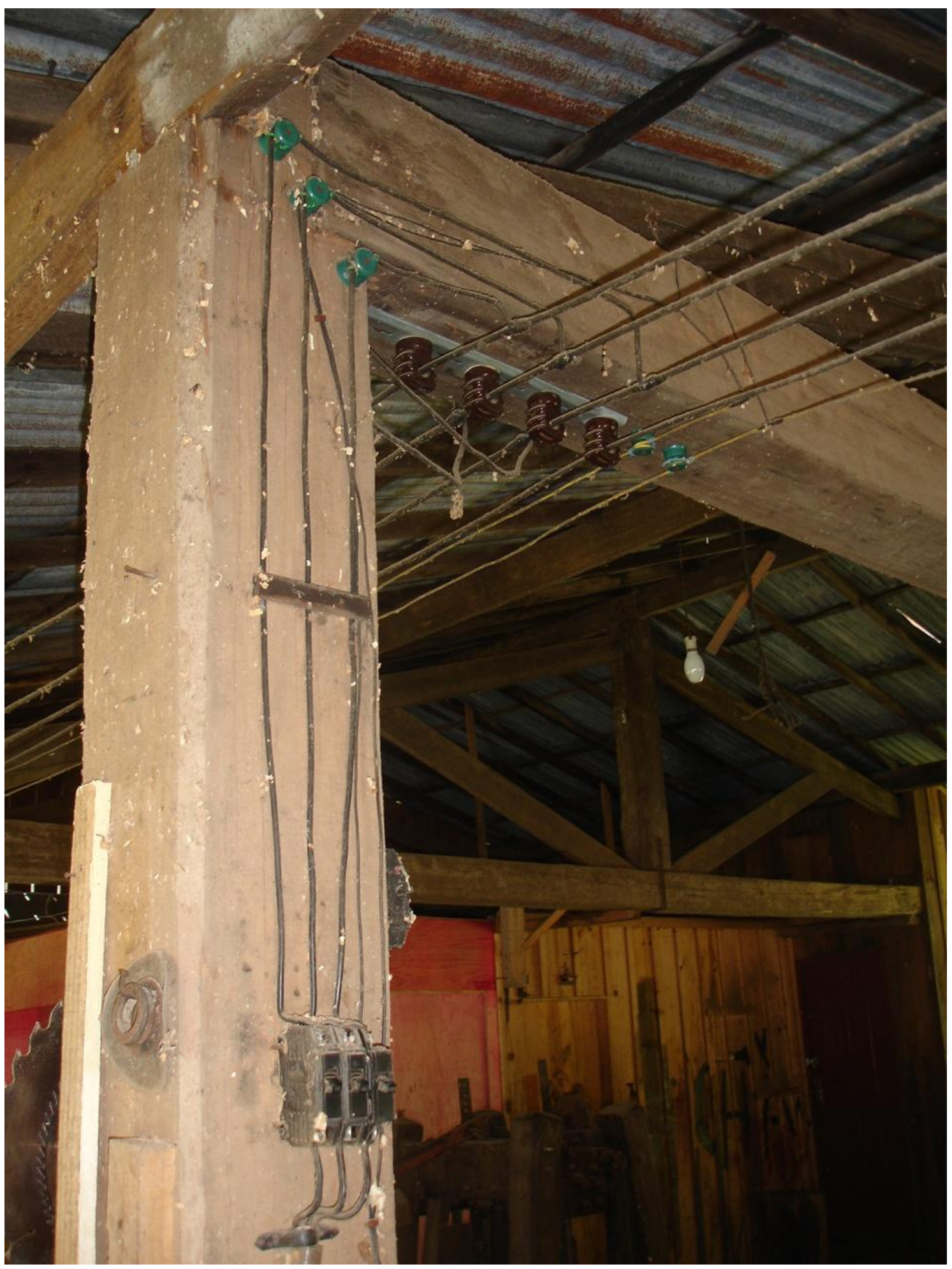

Figura 29: Fiação elétrica exposta e desprotegida na serraria 
$O$ prédio onde se encontra $\mathrm{O}$ auditório, a biblioteca e brinquedoteca (centro de visitantes) é um contra-senso arquitetônico bastante notório (figura 30). No auditório, os assentos não são adequados em altura e largura e não há tratamento acústico (figura 31). A rota de fuga é comprometida pela existência de degraus na saída e ausência de portas de folhas duplas com abertura para fora. Faltam também equipamentos audiovisuais essências para a comunicação (figura 30).

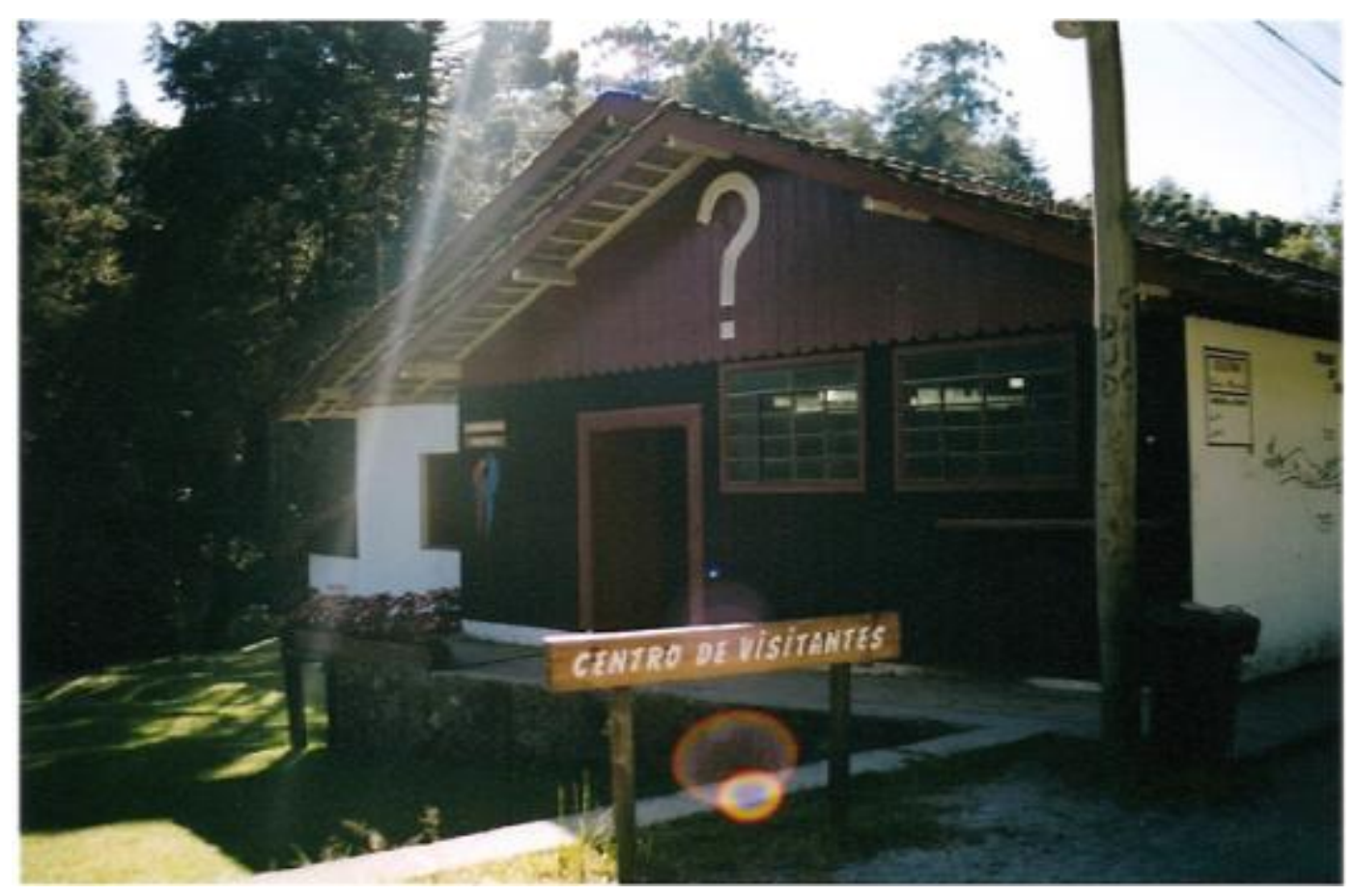

Figura 30: O prédio do centro de visitantes, onde se encontra o auditório, a biblioteca e a brinquedoteca 


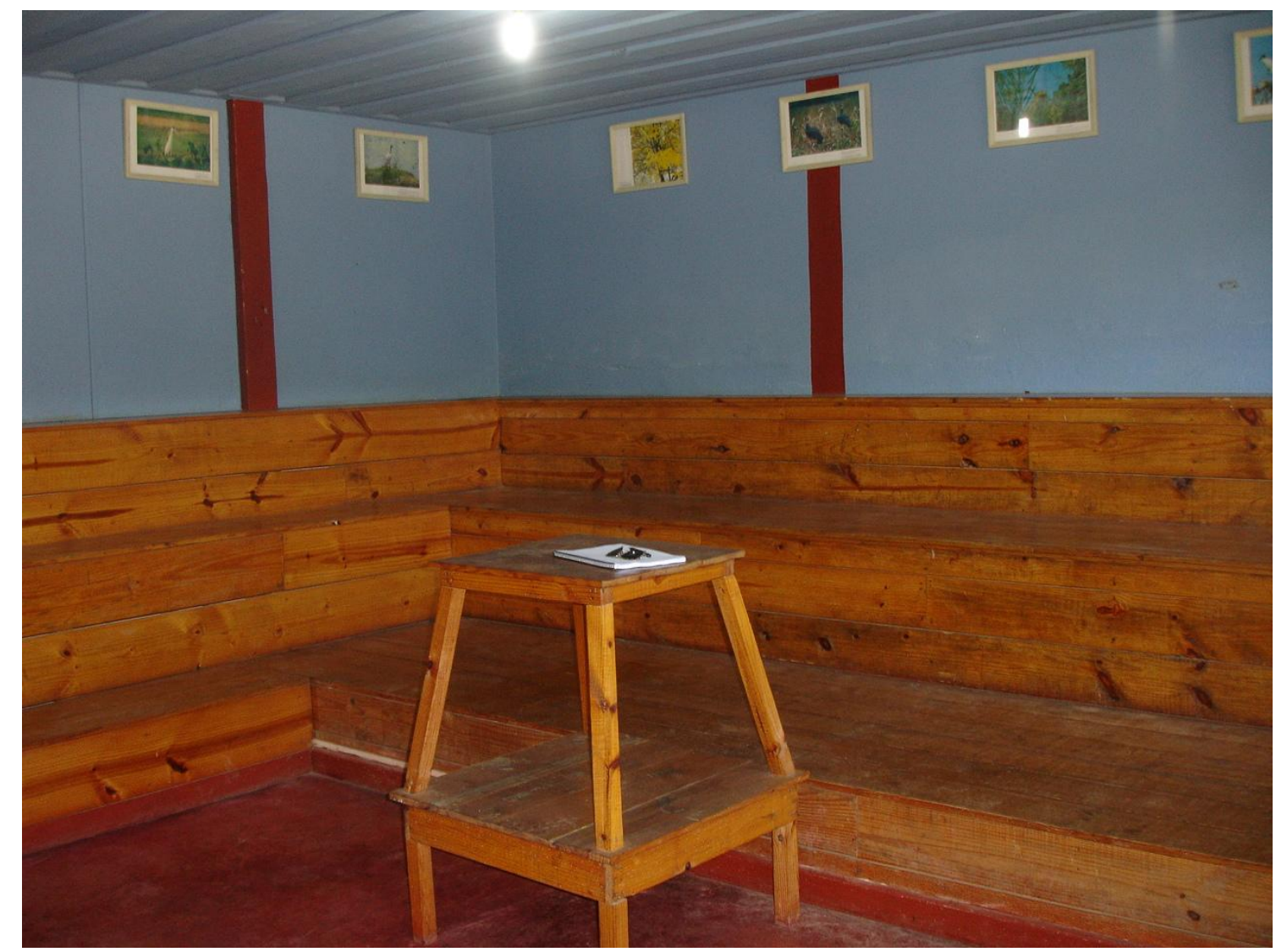

Figura 31: Assentos não são adequados em altura e largura e não há tratamento acústico no auditório

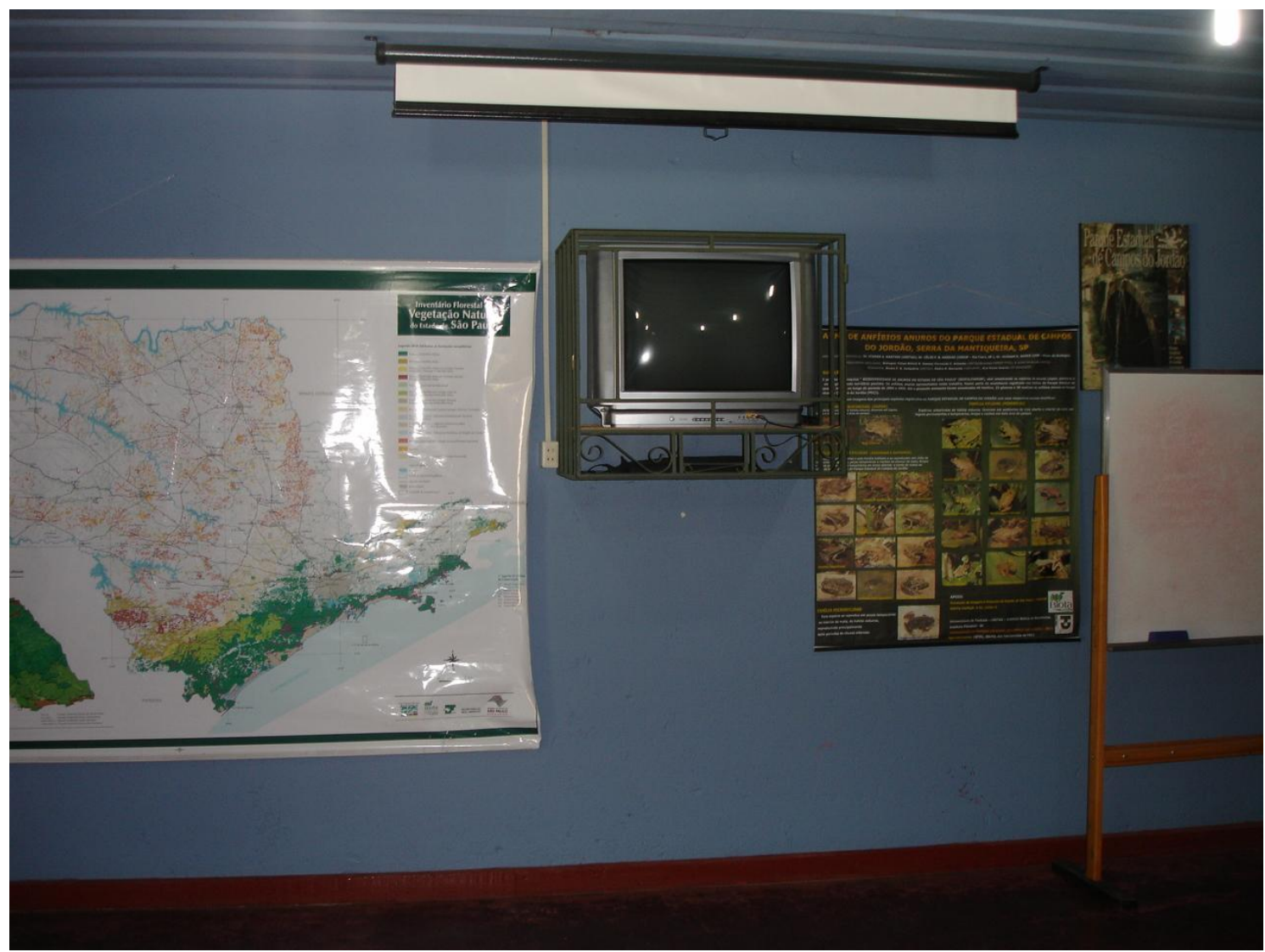

Figura 32: Os poucos equipamentos audiovisuais do auditório 
A biblioteca (figura 33) não tem espaço para leitura e as prateleiras são executadas em madeira, material inadequado que facilita a proliferação de cupins e brocas. Não há um espaço para a desinfecção e catalogação de livros. São poucos os títulos destinados ao assunto específico de parques e sobre a cidade de Campos do Jordão. Mais uma vez nesse equipamento, a arquitetura esconde as visuais do parque.

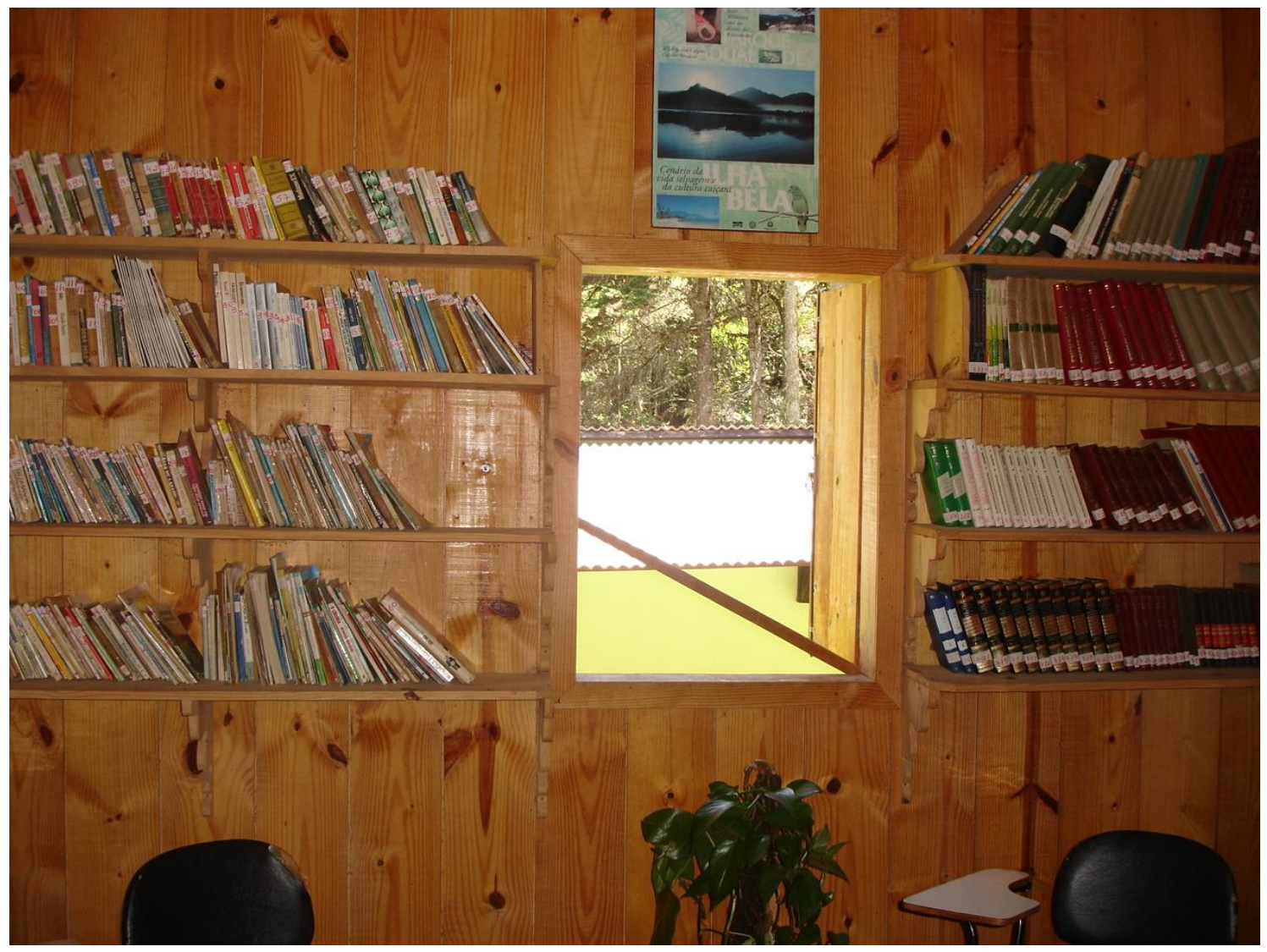

Figura 33: Biblioteca com poucas mesas e falta de espaço para pesquisas.

A biblioteca, inadequadamente, é contígua à Brinquedoteca, local de ruídos (figura 34). 


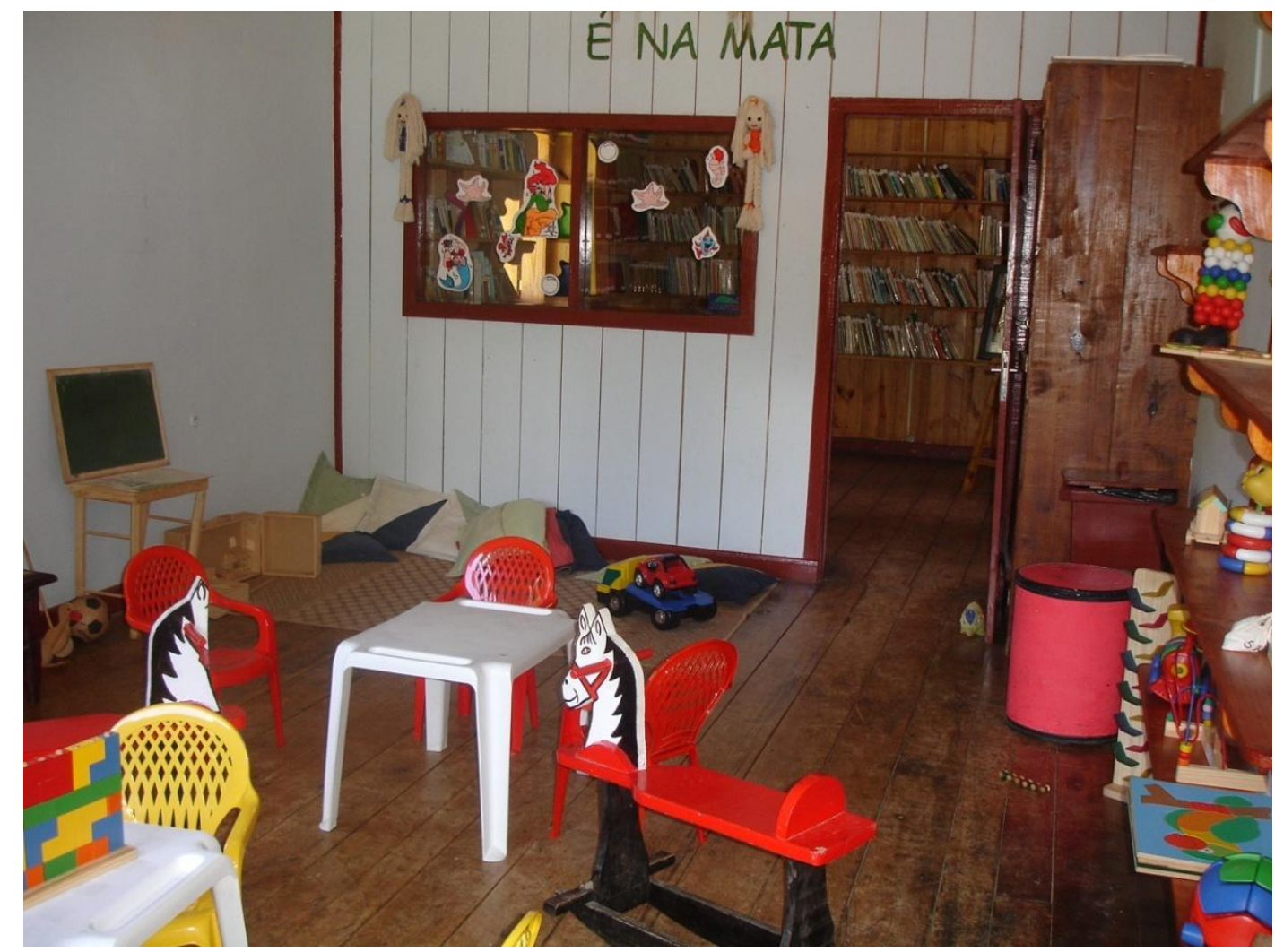

Figura 34: Brinquedoteca contígua a biblioteca

A brinquedoteca apresenta diversos perigos para as crianças como o piso em má conservação, apresentando buracos no chão (figura 35). O acervo de brinquedos é pequeno e se nota painéis em isopor, material inadequado ao manuseio infantil (figura 34). Alguns brinquedos encontram-se em péssimo estado de manutenção (figura 36). A presença de degraus também representa um perigo para as crianças (figura 37 ). 


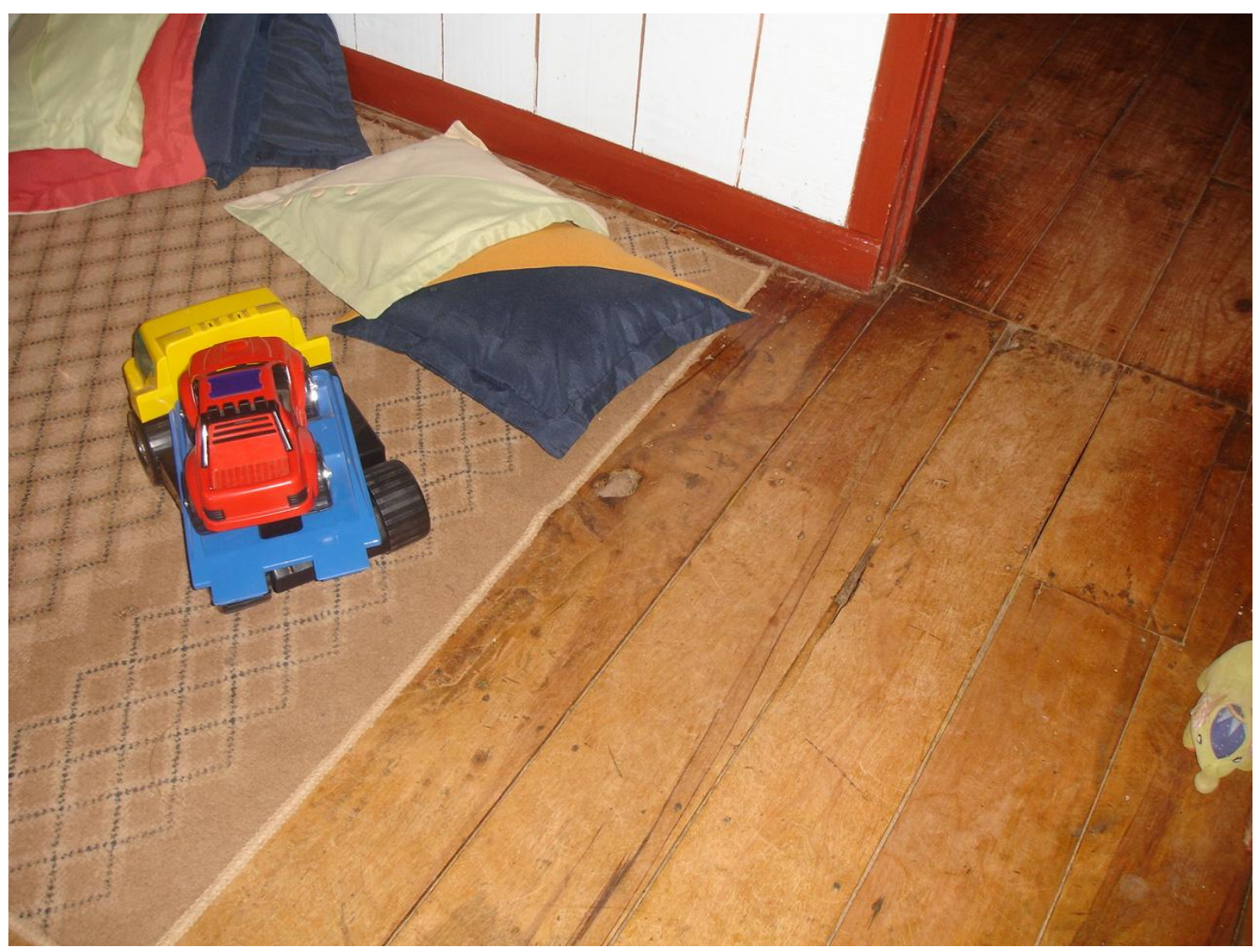

Figura 35: Buracos no chão da brinquedoteca e a presença de carpete



Figura 36: Brinquedo em péssimo estado de conservação 




Figura 37: Presença de degraus na brinquedoteca

O "trenzinho da floresta" é um elogio ao mau gosto, sem nenhum tipo de identificação com a idéia de um Parque (figura 38). Pressupõe-se que o trenzinho deveria ser retirado do parque, uma vez que a sua escala permite caminhadas à pé. Caso haja necessidade de um sistema de locomoção para portadores de necessidades, alguns veículos automotivos de pequeno porte e de tecnologia não poluente deveriam ser reservados. 


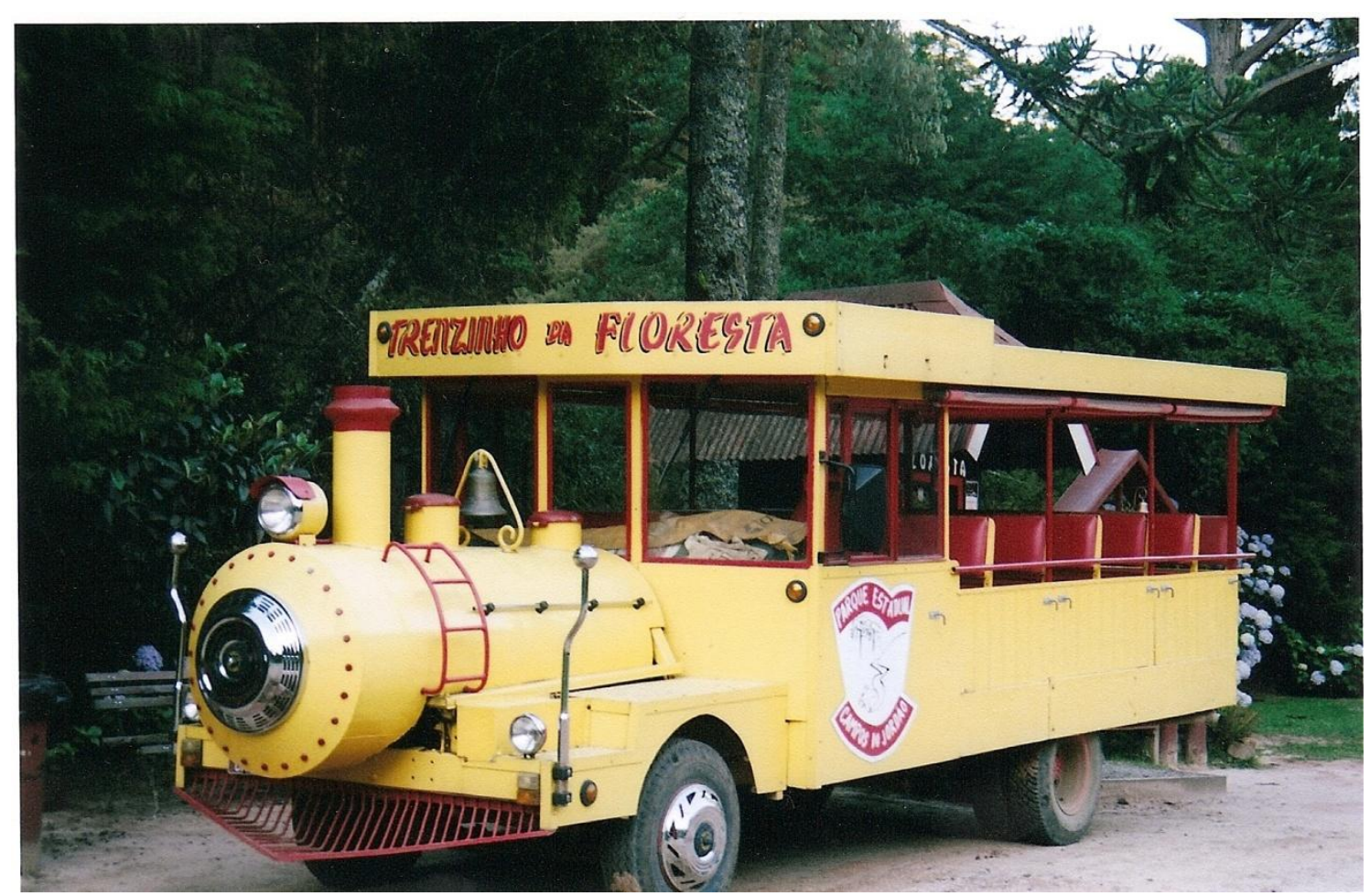

Figura 38: Trenzinho da floresta

O caso mais contundente observado nos equipamentos do parque refere-se à hospedaria e restaurante (figura 39). A construção, predominantemente executada com seções de toras de madeira sobre baldrame em concreto, busca uma arquitetura anacrônica que mimetiza a natureza. Além deste aspecto, observaram-se outros impactos negativos como excesso de umidade, sombreamento demasiado e a presença de insetos. Há um erro na orientação de alguns dos recintos, como os quartos posicionados para a face oeste, com aberturas mínimas (janelas) que esconde algumas das visuais do Parque. 


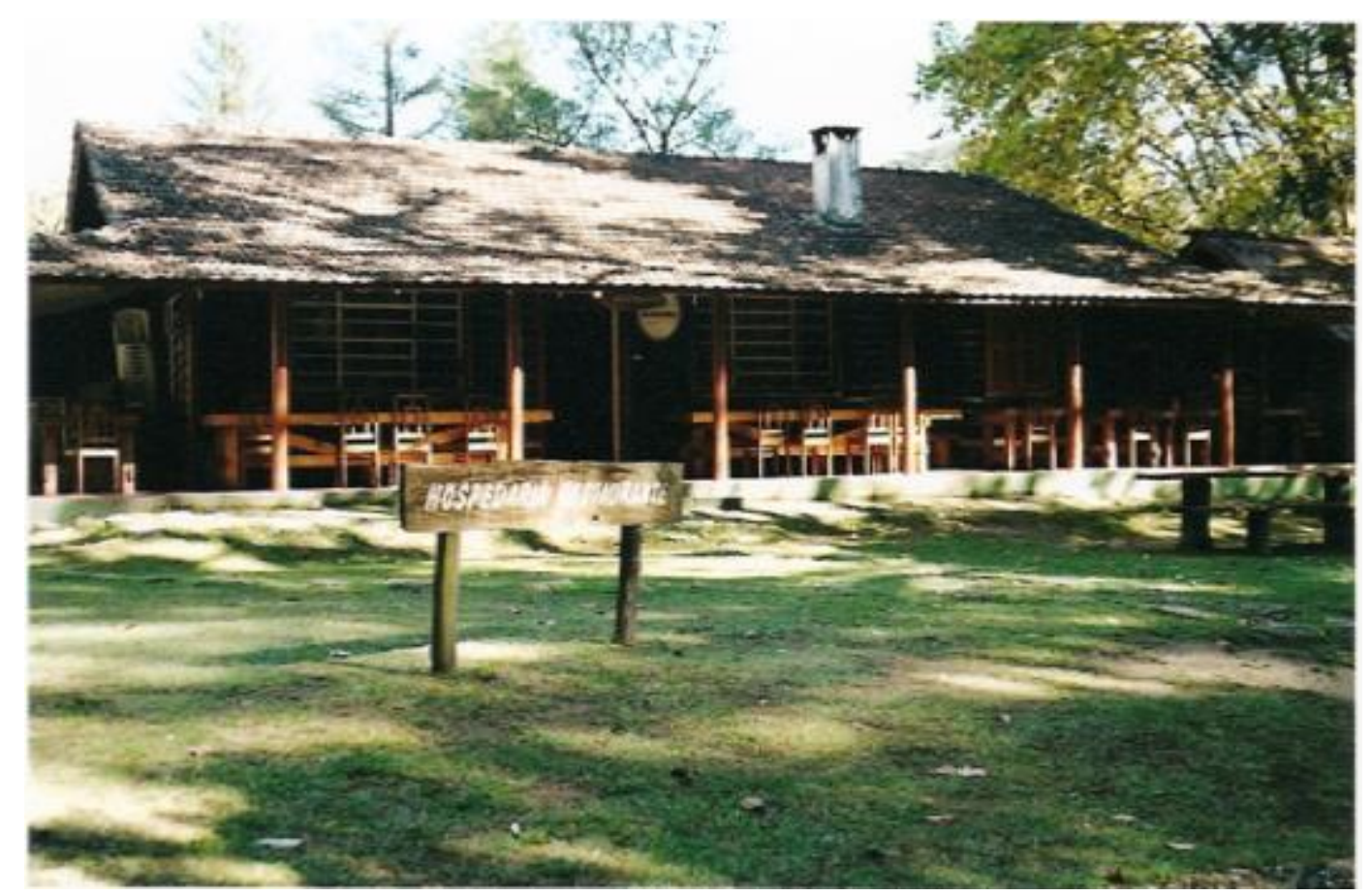

Figura 39: Hospedaria e restaurante do PECJ

A parte coberta do restaurante também não revela a paisagem, assim como a varanda desses é estreita com mobiliária inadequada. Isso foi observado, tanto da sala de estar quanto do restaurante.

O cardápio é pouco variado. Com capacidade total de 20 pessoas, a hospedaria é subdimensionada para quatro pessoas (uma suíte para quatro pessoas e três quartos para quatro pessoas). Os quartos e banheiros não apresentam raios de giro adequados para cadeira de rodas, tampouco outros recursos que contemplem os portadores de necessidades especiais.

As instalações hidráulicas não são dimensionadas adequadamente para o fluxo de água. Os chuveiros elétricos e a torneira do lavatório com fiação aparente e sem o devido aterramento; observa-se também a falta de conduites para a fiação dos interruptores e luminárias. A iluminação é precária, tanto natural quanto artificial (figuras 40-42). 




Figura 40: Instalações elétricas precárias na hospedaria

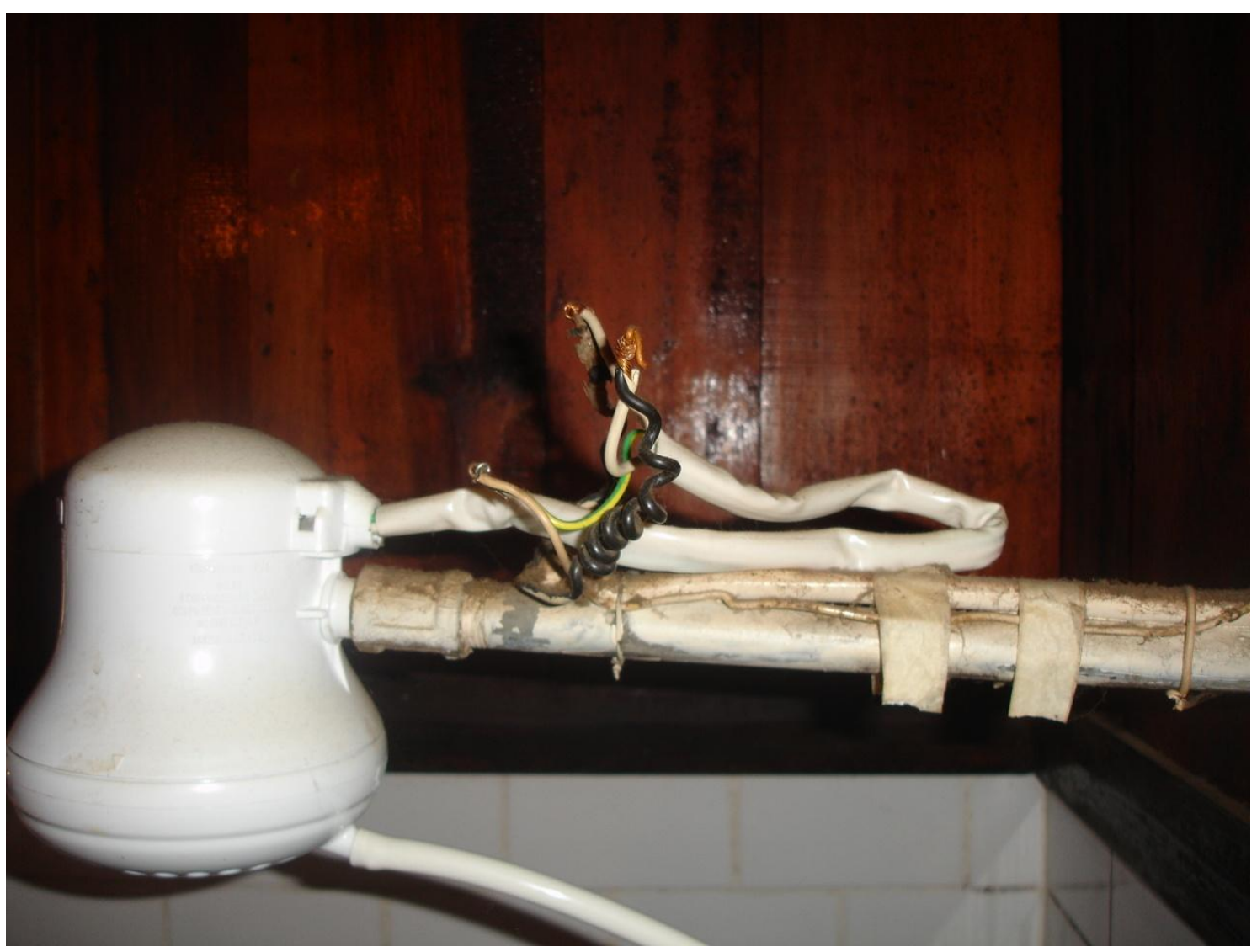

Figura 41: Instalações elétricas precárias na hospedaria 




Figura 42: Falta de conduites para a fiação dos interruptores e luminárias

A caixilharia é inadequada, não há elementos de proteção contra a entrada de ar. A roupa de cama e mesa é ruim. No entanto, os preços são altos: a diária da suíte da hospedaria é de 50 reais e o dormitório é de 30 reais 
por pessoa em cada cama. Vale lembrar que o autor não recebeu nota fiscal na sua estadia na hospedaria.

É importante salientar que o Plano de Manejo do PECJ (1975, p. 79) sente que a cidade tem uma predominância paisagística visual, que deveria ser conservada e que a arquitetura local necessitaria se integrar com a natureza de modo a valorizá-la.



Figura 43: Cartão da hospedaria: a pobreza no desenho do cartão antecipa a precariedade das instalações 
O edifício destinado à sala de exposições e 'museu' possui iluminação natural e artificial precários (figura 44). Como todos os edifícios esparsos, implantados aleatoriamente no contexto da área aedificandi do PECJ, padecem de transparência visual, comprometendo uma bela visão da floresta de araucárias. Os painéis informativos são mal elaborados e de difícil compreensão e os objetos contidos neste espaço não são catalogados e mal identificados (figura 45).

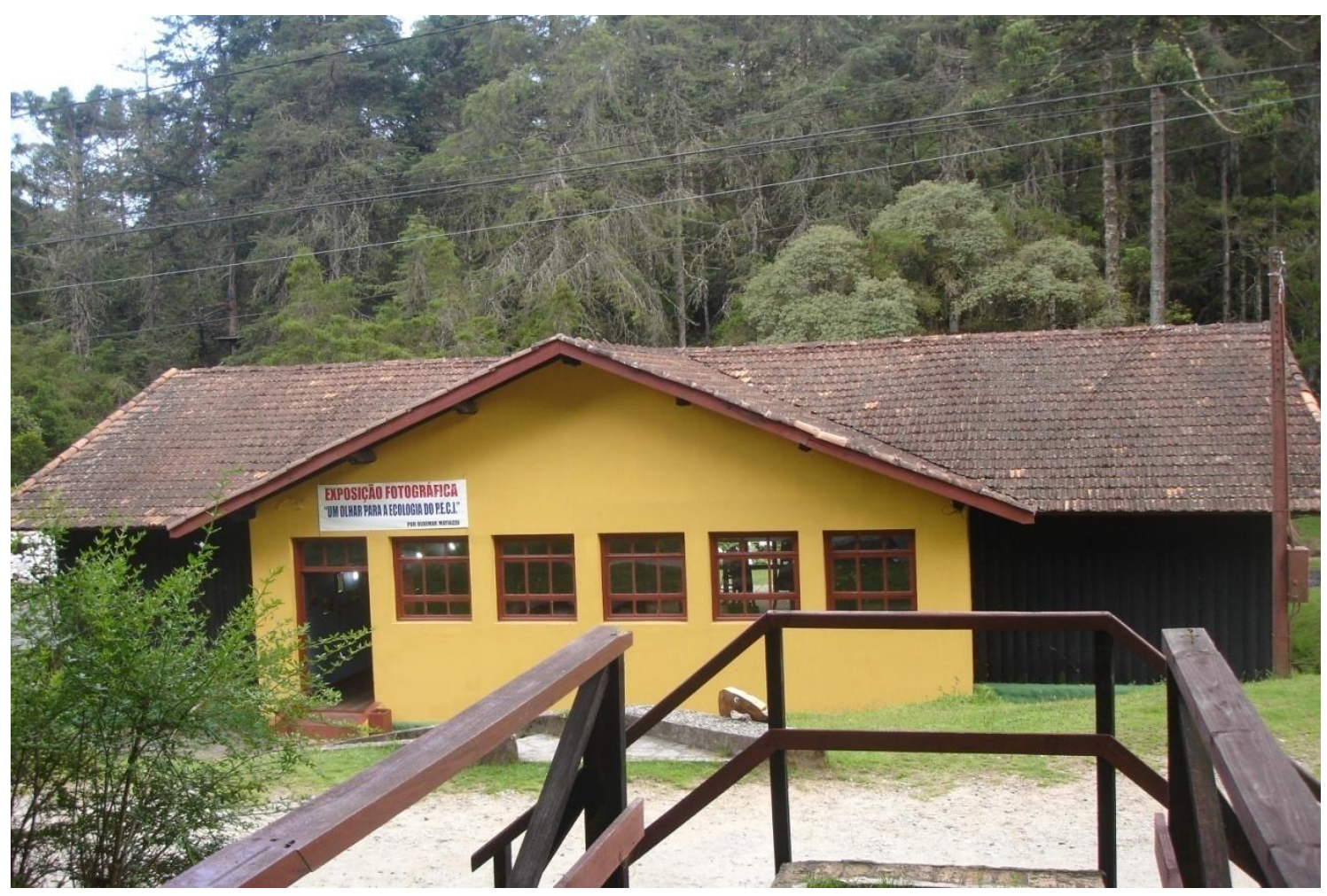

Figura 44: Sala de exposições e 'museu' 




Figura 45: Peça no centro de exposições: mal identificada; ao fundo, as paredes que escondem a paisagem 
Finalmente a articulação entre as edificações, os passeios e calçadas não passam de meras composições de terra batida e cimentados ligando uma às outras, sem contemplar uma promenade arquitetônica e paisagística (figura 45). Importante acrescentar mais dois aspectos na urbanização do parque, a fiação aérea e a iluminação fora da escala do pedestre (figura 47). Os guardacorpos, com peças em madeiramento cruzadas, formando um ' $X$ ', que muitas vezes destroem as melhores visuais do parque (figura 48). Os lixos também não apresentam cores para uma coleta seletiva (figura 49). As placas informativas com o nome científico das espécies não estão adequadas ao padrão internacional (figura 50).

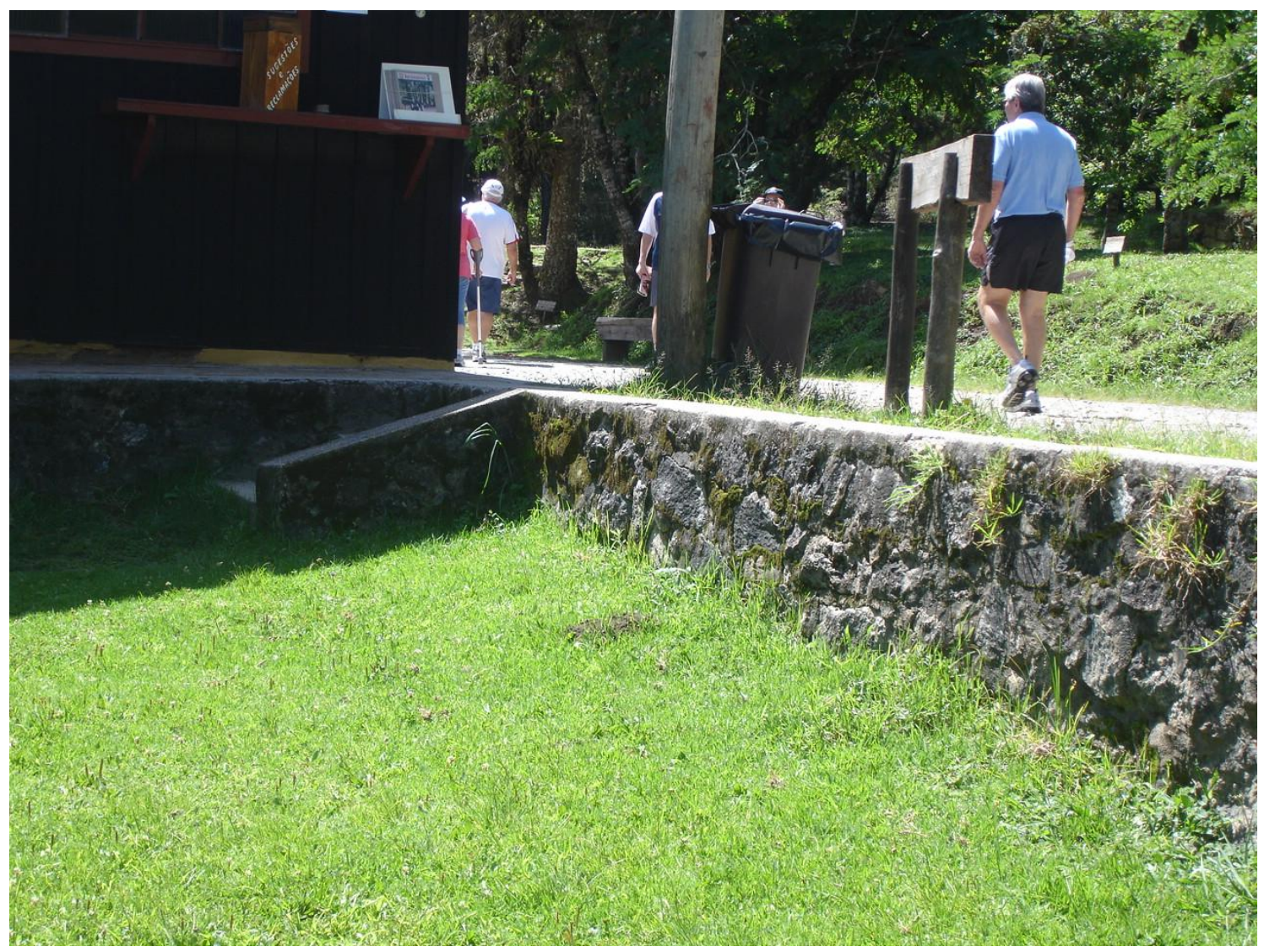

Figura 46: Passeios e calçadas do PECJ não contemplam a paisagem 


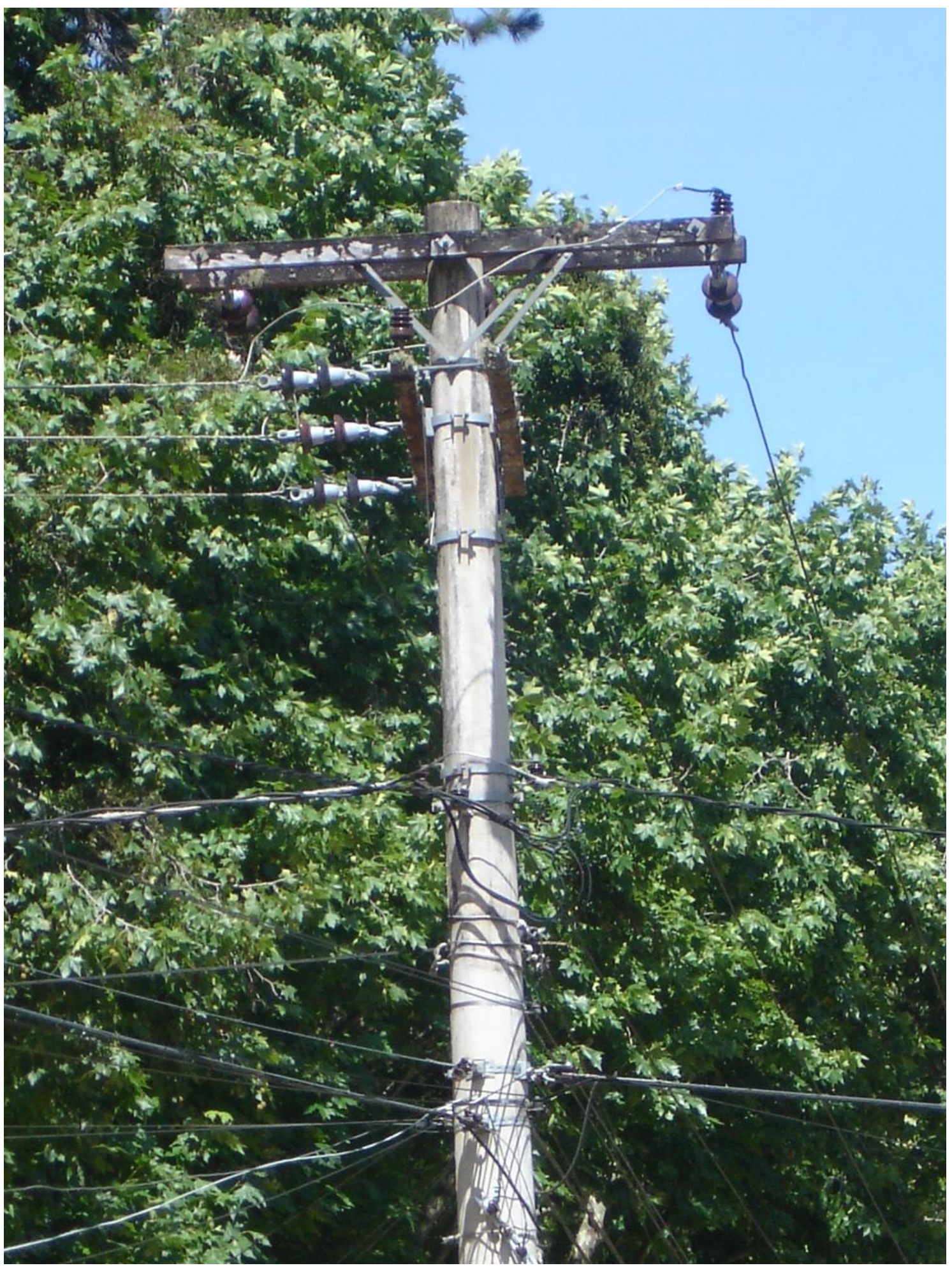

Figura 47: A fiação aérea e a iluminação fora da escala do pedestre 


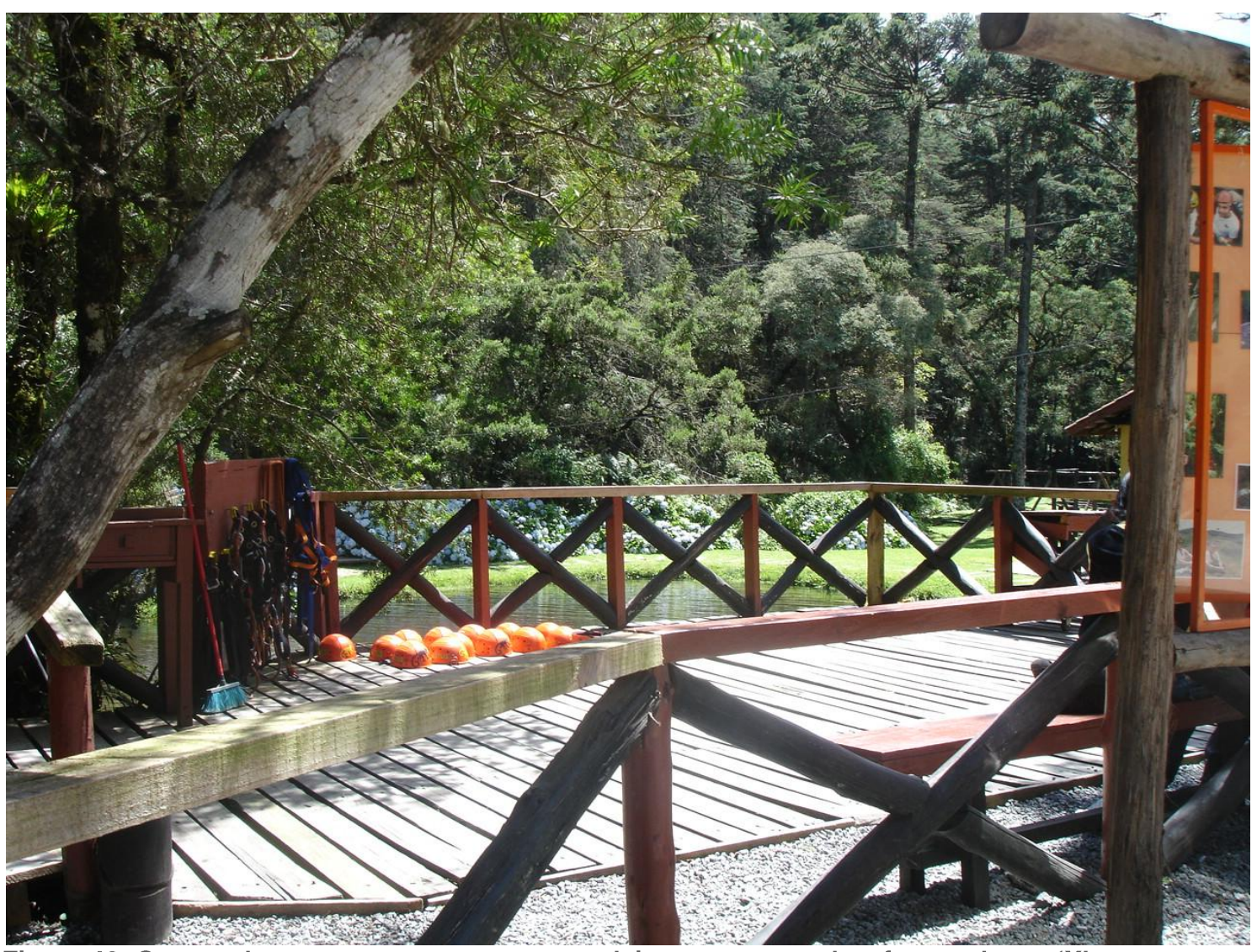

Figura 48: Os guarda-corpos, com peças em madeiramento cruzadas, formando um ' $\mathrm{X}$ '

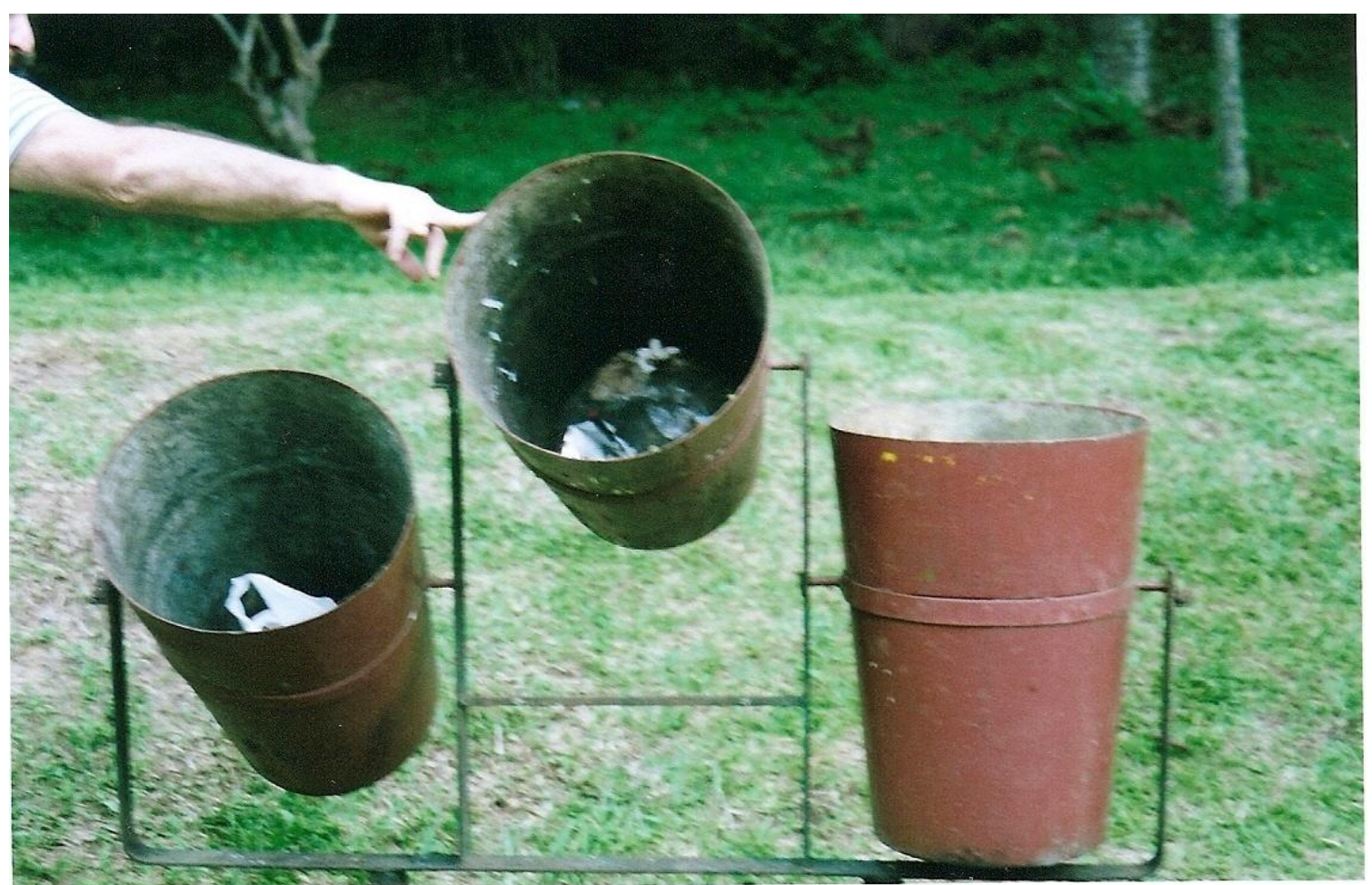

Figura 49: Lixos mal conservados e sem coleta seletiva 


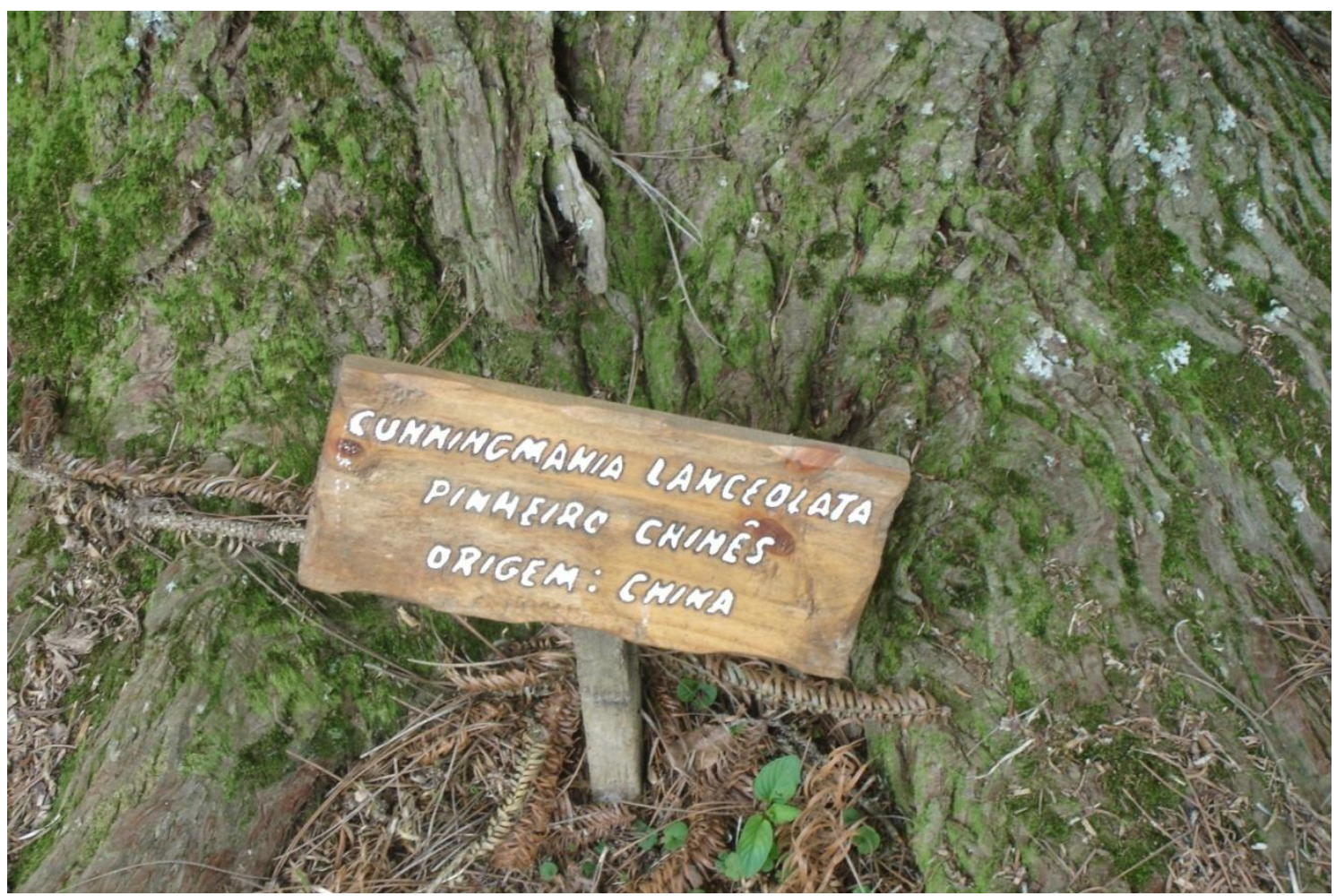

Figura 50: A grafia correta seria Cunninghamia lanceolata. Todas as placas observadas apresentam o mesmo tipo de erro, com todas as letras em maiúscula.



Figura 51: Placa informativa no PECJ. Péssimo estado de conservação na maioria das placas deste tipo. 
O PECJ recebe, anualmente, uma média de 122 mil pessoas, a maior parte concentrada nos meses de junho, julho e agosto ${ }^{8}$. Segundo Barbieri (1997, p. 224), o público visitante do PECJ "apresenta-se satisfeito com a infraestrutura disponível atualmente, em função do seu aspecto mais urbanizado. Mas cabe questionar se o Parque está atendendo seus objetivos de criação no tocante a uso público". A autora (1997, p. 214), elenca algumas conclusões interessantes sobre a visitação no PECJ:

- Existe uma dissociação que os usuários fazem entre a realização de atividades físicas e o conceito de natureza;

- Os motivos pelos quais os visitantes chegam ao Parque não coincidem com as atividades que desenvolvem na Trilha;

- Contradições entre o nível de conhecimento proporcionado e a necessidade de mais informações;

- Preferência por trilhas auto-guiadas;

- Desconhecimento dos objetivos de um parque estadual;

- Devem ser feitos estudos de capacidade carga, para minimizar os impactos;

Segundo Stigliano (2004, p. 161), a maior parte dos visitantes do PECJ considerou sua experiência "totalmente satisfatória", interessante notar que em sua pesquisa a maior parte dos entrevistados respondeu que não tinha nenhum tipo de sugestão de melhorias a fazer no parque $(66,6 \%) ; 15,9 \%$ pediu melhoria nos equipamentos e serviços; $14,5 \%$ na infra-estrutura e $12,5 \%$ nos atrativos.

Segundo Neto, Timoni e Pires (2003, p. 325), "algumas atividades preconizadas no Plano de Manejo do PECJ ainda não foram implementadas, destacando-se a equitação e o campismo, identificando-se fortes demandas para tais e outras ações, como o ciclismo e eventos culturais." O plano de manejo prevê uma área para camping que ainda não existe no Parque.

\footnotetext{
${ }^{8}$ Média a partir dos dados de Gallo Junior, 2000, p. 159.
} 
Vale acrescentar que no Informativo do PECJ de dezembro de 2007, não existem informações sobre qualquer evento no parque. No Informativo de setembro de 2007, há uma programação para a 'Semana da Árvore 2007', com caminhadas, palestras e eventos de educação ambiental. Mas os informativos, de caráter trimestral, são pobres em conteúdos sobre o PECJ. O lançamento de livros de fotografias ou de uma revista sobre o PECJ seria mais uma maneira de captar recursos.

A cidade de Campos do Jordão recebe um grande número de turistas com alto poder aquisitivo. Em reportagem publicada no site 'A Página de Campos', o shopping 'Market Plaza', aberto apenas da alta temporada, chama atenção que "além de ser freqüentado por um público de alto poder aquisitivo, desde 2004, vem superando até o famoso Horto Florestal em número de visitas. Campos do Jordão, na alta temporada, reúne mais de 1 milhão de turistas e, no ano passado, só o shopping recebeu mais de 345 mil visitantes, sendo que $74 \%$ de seus freqüentadores são da classe $A, 56 \%$ mulheres e $26 \%$ com renda superior a $R \$ 10$ mil'”.

\footnotetext{
${ }^{9} \mathrm{http} / / /$ www.apaginadecampos.com.br/index.html (acesso em 27/02/2008)
} 


\section{Considerações finais}

Os parques, dotados de significativa beleza natural, devem ser conservados para a manutenção do ecossistema. São áreas públicas que devem permanecer como uma herança para a humanidade. Estas unidades de conservação apresentam benefícios para o ser humano e a sua conservação depende de esforços públicos e privados.

Os parques, como áreas de proteção integral devem respeitar seu objetivo primordial de conservação da natureza, mas também são áreas de visitação e, portanto, devem ser tratadas como tal.

Os parques brasileiros apresentam um índice de visitação baixo quando comparado a diversos parques no mundo, como foi examinado no capítulo 3. Diversos fatores competem para que este índice seja baixo e a falta de infraestrutura turística adequada reflete neste indicador.

A infra-estrutura turística em parques merece atenção e cuidados que, em diversos casos, os parques nacionais não conseguem atender. A falta de recursos ou a má administração mantém estes serviços, muitas vezes em estado de precariedade.

A cidade de Campos do Jordão recebe um grande número de turistas, cerca de 3,6 milhões por ano, que não visitam o Parque Estadual de Campos do Jordão (PECJ) possivelmente pela precariedade da infra-estrutura e da falta de divulgação (o parque recebe anualmente cerca de 130 mil visitantes), deixando grande parte dos recursos na cidade ou mesmo nos restaurantes e hotéis no entorno do PECJ, que aproveitam a paisagem da região.

Apesar de alguns autores apontarem o PECJ como uma das unidades de conservação melhor preparada para receber o turista, o que se constatou foram diversos obstáculos para uma maior abertura. 
O trabalho verificou que o PECJ apresenta múltiplos serviços precários e, até mesmo perigosos que podem acarretar acidentes e incêndios em uma área de proteção ambiental.

A pesquisa assinalou algumas sugestões para um melhor aproveitamento do parque, como a retirada do estacionamento e melhorias atinentes à acessibilidade e do possível aproveitamento do potecial paisagístico da área, talvez uma das mais significativas da cidade de Campos do Jordão.

Tais melhorias, que devem ser discutidas com um corpo técnico interdisciplinar, com os usuários do parque e com a população local, proporcionariam, provavelmente, um maior fluxo de visitação. Evidentemente, respeitada a capacidade de carga do parque.

Cabe ressaltar que as soluções adotadas para uma maior abertura turística devem ser compatíveis com a idéia de parque, evitando assim que sejam transformados em 'parques de diversão'.

A Área de Uso Público do PECJ apresenta uma cadeia de serviços que estão em condições precárias ou não exploram as características naturais do parque. A principal via de acesso, a 'Estrada do Horto', com obras não concluídas, representa o primeiro obstáculo. As placas informativas estão deterioradas ou são de difícil leitura.

Os equipamentos de uso público do PECJ como a cantina, a lanchonete, os banheiros, o centro de exposições, a biblioteca e o centro de visitantes apresentam problemas recorrentes como: falta de acessibilidade e fiação exposta, além de não apresentarem locais para a contemplação da paisagem, grande atrativo do parque. 
O orquidário e o viveiro de mudas, outro grande atrativo, se mostra desorganizado. O playground, com brinquedos antigos, dificulta uma interação entre a criança e a natureza.

A hospedaria do PECJ, com preços altos, apresenta quartos pequenos, com fiação exposta, banheiros precários e sem acessibilidade. Suas janelas pequenas não contemplam a paisagem do Parque. $O$ restaurante anexo a hospedaria, apresenta os mesmos problemas percebidos no parque.

Além de uma revisão contundente nos equipamentos, seria pertinente a existência de uma programação cultural, utilizando áreas como, por exemplo, o estacionamento para concertos, evidentemente com equipamentos apropriados.

O trabalho buscou atender seus objetivos na medida em que se constatou a precariedade dos equipamentos do PECJ e como tal infra-estrutura acaba não atraindo visitantes ao Parque. As instalações em mal estado de conservação também colocam em risco o ecossistema, natural do Parque.

Um dos principais focos da pesquisa é contribuir para a atualização do Plano de Manejo do PECJ, bem como para futuras intervenções na rede de serviços do Parque 


\section{Bibliografia}

AMARAL E SILVA, Carlos Celso; "Gerenciamento de Riscos Ambientais"; In: Curso de Gestão Ambiental (org- Philippi Jr, A.; Romero, M. A.; Bruna, G. C.); Editora Manole; Baureri: 2004; págs 791-804.

BARBIERI, Marília Gonçalves; "Análise de Programas de Uso Público em Unidades de Conservação do Estado de São Paulo - Revisão e Estudo de Caso para o Parque Estadual de Campos do Jordão"; Dissertação de Mestrado. PROCAM/USP. São Paulo: 1997. 238p.

BARRETO Filho, Henyo Trindade; CESAR, Alexandre Luís; Paula, Daniela de; GRANDO Júnior, Euclides Selvino; FALEIRO, Rodrigo Paranhos; GANEN, Roseli Senna; "Proposta de um procedimento para a criação de Unidades de Conservação"; in: Políticas Ambientais no Brasil (orgo Little, Paul E.); Editora Peirópolis; São Paulo: 2003; págs. 133-165.

BOO, Elizabeth; "O Planejamento Ecoturístico para Áreas Protegidas"; in: Ecoturismo - Um Guia Para Planejamento e Gestão (editores: Lindberg, Kreg; Hawkins, Donald E.); Editora Senac; São Paulo: 2001 (3를 Edição). Págs. 33-57.

BRASIL; Leis, decretos etc. - Lei № 9.985 de 18 de Julho de 2000. Brasil. Casa Civil. Subchefia Para Assuntos Jurídicos. 16p.

BRITO, M. C. Wey de; "Unidades de Conservação: intenções e resultados"; Annablume: Fapesp, São Paulo: 2002. 230p.

BOYD, Stephen W.; "Tourism, National Parks and Sustainability"; In: Tourism and National Parks - Issues and Implications (edited by Butler, Richard W.; Boyd, Stephen W.); John Wiley \& Sons, Ltd.; England: 2000. Págs. 161-186.

CABRAL, Nájila Rejanne A. Julião; SOUZA, Marcelo Pereira de; "Área de Proteção Ambiental - Planejamento e Gestão de Paisages Protegidas"; Editora Rima; São Carlos: 2005 (2ª Edição). 158p. 
CALDERONI, Sabetai; "Economia Ambiental"; In: Curso de Gestão Ambiental (org ${ }^{\mathrm{a}}$ Philippi Jr, A.; Romero, M. A.; Bruna, G. C.); Editora Manole; Baureri: 2004; págs. 571-616.

CAMPOS DO JORDÃO; "Campos do Jordão: História e Poesia"; São Paulo: Artemeios, 2007.

CRESSWELL, C.; MACLAREN, F.; "Tourism and National Parks in Emerging Tourism Countries"; in: Tourism and National Parks - Issues and Implications (edited by Butler, Richard W.; Boyd, Stephen W.); John Wiley \& Sons, Ltd.; England: 2000. Págs. 283-299.

DAVENPORT, Lisa; BROCKELMAN, Warren Y.; WRIGHT, Patrícia C.; RUF, Karl; DEL VALLE, Fernando B. Rubio; "Ferramentas de Ecoturismo para Parques"; In: Tornando os Parques Eficientes (org ${ }^{-}$Terborgh, John; Van Schaik, Carel; Davenport, Lisa; Rao, Mandhu); Editora da UFPR; Curitiba: 2002; págs. 305-333.

DOUROJEANNI, Marc J.; "Vontade Política para Estabelecer e Manejar Parques"; In: Tornando os Parques Eficientes (org ${ }^{\circ}$ Terborgh, John; Van Schaik, Carel; Davenport, Lisa; Rao, Mandhu); Editora da UFPR; Curitiba: 2002; págs. 347-362.

DRUMMOND de Castro, Paula F.; "Ciência e Gestão em Unidades de Conservação: o caso do Parque Estadual Turístico do Alto Ribeira PETAR, SP"; Dissertação de Mestrado. IG/Unicamp; Campinas: 2004. 115p.

EAGLES, Paul F. J.; McCOOL, Stephen; "Tourism In National Parks and Protected Areas - Planning and Management"; CABI Publishong; UK; 2004; 320p. 
EMBRATUR; "Estudo Sobre o Turismo Praticado em Ambientes Naturais Conservados - Relatório Final”; Embratur; São Paulo: 2002; 161p. Disponível em institucional.turismo.gov.br. Acesso em 20/04/2007.

FENNELL, David A.; "Ecotourism: an Introduction"; Routledge; London: 1999. $315 p$.

FILION, Fern L.; FOLEY, James P.; JACQUEMOT, André J.; "The Economics of Global Ecotourism" in "Protected Area Economics and Policy"; Distributed for the World Conservation Union (IUCN) by The World Bank; Washington, D.C.: 1994; págs. 235-252.

GALLO JUNIOR, Humberto; "Análise da Percepção Ambiental de Turistas e Residentes, como Subsídio ao Planejamento e Manejo do Parque Estadual de Campos do Jordão/SP"; Dissertação de Mestrado. FFLCH/USP; São Paulo: 2000. 195p.

GOMES OREA, D.; "El medio ambiente y los recursos naturales em la planificación". In GOMES OREA, D. El medio físico y la planificación. Madrid: CIFCA, 1978. p. 13-59.

IBAMA; "Plano de Manejo do Parque Nacional do Iguaçu"; IBAMA; Brasília: 1999. Disponível em www.ibama.gov.br. Acesso em 01/04/2007.

IF (Instituto Florestal); "Plano de Manejo do Parque Estadual da Serra do Mar"; Instituto Florestal e Instituto EkosBrasil. IF; São Paulo: 2006. Disponível em www.iflorestal.sp.gov.br. Acesso em 01/04/2007.

; "Plano de Manejo do Parque Estadual de Porto Ferreira"; Instituto Florestal. IF; São Paulo; 2003. Disponível em www.iflorestal.sp.gov.br. Acesso em 01/04/2007. 

; "Plano de Manejo do Parque Estadual de Campos do Jordão"; in: Boletim Técnico no19; IF; São Paulo: Dezembro, 1975. 153p.

; "Atlas do Plano de Manejo do Parque Estadual de Campos do Jordão"; in: Boletim Técnico no19; IF; São Paulo: Dezembro, 1975. 12 mapas.

IUCN; "Guidelines For Protected Area Management Categories"; IUCN, Gland; UK: 1994. 83p.

IUCN; "Managing Protected Areas in the Tropics"; IUCN; UK: 1986. 295p.

KINKER, Sônia; "Ecoturismo e Conservação da Natureza em Parques Nacionais"; Campinas, SP; Papirus, 2002, 224p.

LAGE, Beatriz H. G.; MILONE; Paulo C.; "Turismo na Economia"; Editora Aleph; São Paulo: 2004. 94p.

LASCURÁIN-CEBALLOS, Héctor; "O Ecoturismo Como Um Fenômeno Mundial"; in: Ecoturismo - Um Guia Para Planejamento e Gestão (editores: Lindberg, Kreg; Hawkins, Donald E.); Editora Senac; São Paulo: 2001 (3 Edição). Págs. 25-29.

LINDBERG, Kreg; HUBER Jr., Richard M.; "Questões Econômicas na Gestão do Ecoturismo" in: Ecoturismo - Um Guia Para Planejamento e Gestão (editores: Lindberg, Kreg; Hawkins, Donald E.); Editora Senac; São Paulo: 2001 (3를ição). Págs. 145-195.

LUCAS, P. H. C.; "Protected Landscapes"; Chapman \& Hall; London: 1992. 297p.

LAURIE, M.; "La naturaleza y el hombre: arquitectura del paisaje"; in LAURIE, M. Introducción a la arquitectura del paisaje. Barcelona: Gustavo Gili, 1983. p. 11-28. 
; "Planificación del paisaje". in LAURIE, M. Introducción a la arquitectura del paisaje. Barcelona: Gustavo Gili, 1983. p. 127-169.

MAGALHÃES, M. R.; "Arquitectura paisagista: conceitos"; in MAGALHÃES, M. R. A arquitectura paisagística: morfologia e complexidade. Lisboa: Editorial Estampa, 2001. p. 29-70.

MARCONDES, Marco Antonio Pupio; "Adaptacion Y Comprobacion de Uma Metodologia de Evaluacion Economica, aplicada al Parque Nacional Cahuita, Costa Rica"; Dissertação de Mestrado; Centro Agronômico Tropical de Investigación y Enseñanza; Programa de Recursos Naturales Renovables; Turrialba, Costa Rica; 1980. 124p.

; "Editorial: Palavra do Diretor"; in: Informativo do Parque Estadual de Campos do Jordão; IF, Ano III, no 12, Campos do Jordão/SP: Abril/2007.

MORSELLO, Carla; "Áreas Protegidas públicas e privadas: seleção e manejo"; Annablume/Fapesp, São Paulo: 2001. 343p.

NEPAL, Sanjay K.; "Tourism, National Parks and Local Communities"; In: Tourism and National Parks - Issues and Implications (edited by Butler, Richard W.; Boyd, Stephen W.); John Wiley \& Sons, Ltd.; England: 2000. Págs. 73-94.

NETO, J. E. DE. M.; TIMONI, J. L.; PIRES, A. S.; "Ingerência Privada no Parque Estadual de Campos do Jordão"; in: Anais do II Simpósio de Áreas Protegidas. 2003. Disponível em sap.ucpel.tche.br. Acesso em 20/04/2007.

NPS (National Park Service, USA); "Yellowstone National Park Business Plan"; National Park Service; USA: July, 2003. 46p. 
ORTIZ, Ramon Arigoni; "Valoração Econômica Ambiental"; In: Economia do Meio Ambiente (org ${ }^{\circ}$ May, P. H.; Lustosa, M. C.; Vinha, V.); Editora Elsevier; Rio de Janeiro; 2003; págs. 81-99

ROMEIRO, Ademar Ribeiro; "Economia ou economia política da sustentabilidade?"; Texto para Discussão, IE/UNICAMP no102, set. 2001. 28p.

ROMEIRO, Ademar Ribeiro; MAIA, G. Alexandre; REYDON, P. Bastiaan; "Valoração de recursos ambientais - metodologias e recomendações"; Texto para Discussão, IE/UNICAMP no116, mar. 2004. 38p.

RUSCHMANN, Doris van de M.; "Turismo e Planejamento Sustentável: A Proteção do Meio Ambiente"; Papirus, Campinas/SP: 1997. 199p.

SÃO PAULO. Decreto ํo 25.341 de 04 de junho de 1986.

SANO, Nara Nanae; "Estudo Comparado da Gestão das Visitações nos Parques Estaduais Turísticos do Alto da Ribeira (PETAR) e Intervales (PEI)"; Dissertação de Mestrado. FFLCH/USP; São Paulo: 2007. 133p.

SANTOS, Rozely Ferreira dos; "Planejamento Ambiental: teoria e prática"; Oficina de Textos; São Paulo: 2004; 184p.

SPERGEL, Barry; "Financiamento de Áreas Protegidas"; In: Tornando os Parques Eficientes (orgํㅜ Terborgh, John; Van Schaik, Carel; Davenport, Lisa; Rao, Mandhu); Editora da UFPR; Curitiba: 2002; págs. 334-413.

STIGLIANO, Beatriz V.; "Visitantes em Unidades de Conservação - O Método VAMP Aplicado ao Parque Estadual de Campos do Jordão/SP"; Dissertação de Mestrado. ECA/USP; São Paulo: 2004. 189p. 
TAKAHASHI, Leide; "Uso Público em Unidades de Conservação"; In: Cadernos de Conservação; Ano 02, no 02. Fundação O Boticário de Proteção à Natureza, Curitiba: outubro/2006.

TERBORGH, John; VAN SCHAIK, Carel; "Por que o Mundo Necessita de Parques"; In: Tornando os Parques Eficientes (org ${ }^{-}$Terborgh, John; Van Schaik, Carel; Davenport, Lisa; Rao, Mandhu); Editora da UFPR; Curitiba: 2002; págs. 25-36.

TERBORGH, John; PERES, Carlos A.; "O Problema das Pessoas nos Parques"; In: Tornando os Parques Eficientes (org ${ }^{\circ}$ Terborgh, John; Van Schaik, Carel; Davenport, Lisa; Rao, Mandhu); Editora da UFPR; Curitiba: 2002; págs. 334-346.

TERBORGH, John; DAVENPORT, Lisa; "Monitorando as Áreas Protegidas"; In: Tornando os Parques Eficientes (org ${ }^{-}$Terborgh, John; Van Schaik, Carel; Davenport, Lisa; Rao, Mandhu); Editora da UFPR; Curitiba: 2002; págs. 426439.

VASCONCELLOS, Jane M. de O.; "Educação e Interpretação Ambiental em Unidades de Conservação"; In: Cadernos de Conservação; Ano 03, № 04. Fundação O Boticário de Proteção à Natureza, Curitiba: dezembro/2006.

VENTURI, Luis Antonio Bittar; "Parque Nacional das Emas: Gestão e Degradação"; Dissertação de Mestrado. FFLCH/USP; São Paulo: 1993. 122p.

YÁZIGI, Eduardo. Turismo: uma esperança condicional. São Paulo: Editora Global, $3^{\circ}$ edição, 2003.

, Eduardo. Civilização Urbana - Planejamento e Turismo: discípulos do amanhecer. São Paulo: Editora Contexto, 2003. 
, Eduardo. A Alma do Lugar - Turismo, Planejamento e Cotidiano. São

Paulo: Editora Contexto, 2002.

\section{Revistas e Jornais}

National Geographic - October, 2006 - Vol. 210 - no04 - págs. 72-97.

Guia Quatro Rodas - Brasil - 2007 - Editora Abril.

Estado de São Paulo - Caderno Vida\& - 30 de dezembro de 2007.

\section{Folhetos}

IF - Parque Estadual Campos do Jordão - SMA/IF - Série Institucional nำ10 Junho/2002.

Informativo - Parque Estadual de Campos do Jordão - Ano III - № 14 Setembro/2007

Informativo - Parque Estadual de Campos do Jordão - Ano III - № 15 Dezembro/2007 
Anexos

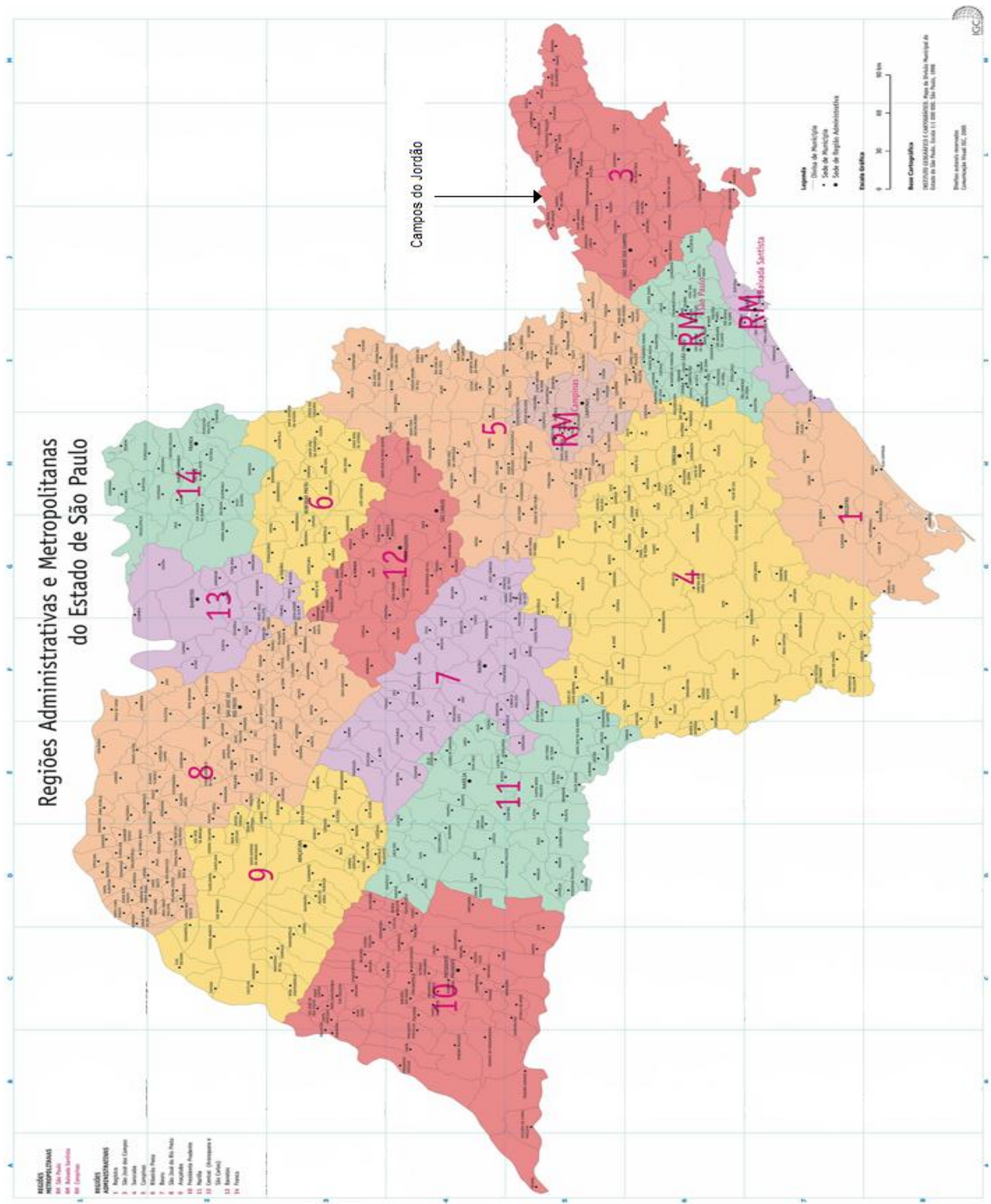

Figura 52: Mapa das Regiões Administrativas e Metropolitanas do Estado de São Paulo 